\title{
ION EXCHANGE TECHNOLOGY ASSESSMENT REPORT (U)
}

\author{
by E.F. Duhn
}

Westinghouse Savannah River Company

Savannah River Site

Aiken, South Carolina 29808

Other Authors: $N / A$

This paper was prepared in connection with work done under Contract No. DE-AC09-89SR18035 with the U. S. Department of Energy. By acceptance of this paper, the publisher and/or recipient acknowledges the U. S. Government's right to retain a nonexclusive, royalty-free license in and to any copyright covering this paper, along with the right to reproduce and to authorize others to reproduce all or part of the copyrighted paper. 


\section{DISCLAIMER}

This report was prepared as an account of work sponsored by an agency of the United States Government. Neither the United States Government nor any agency thereof, nor any of their employees, makes any warranty, express or implied, or assumes any legal liability or responsibility for the accuracy, completeness, or usefulness of any information, apparatus, product, or process disclosed, or represents that its use would not infringe privately owned rights. Reference herein to any specific commercial product, process, or service by trade name, trademark, manufacturer, or otherwise does not necessarily constitute or imply its endorsement, recommendation, or favoring by the United States Government or any agency thereof. The views and opinions of authors expressed herein do not necessarily state or reflect those of the United States Government or any agency thereof.

This report has been reproduced directly from the best available copy.

Available to DOE and DOE contractors from the Office of Scientific and Technical Information, P. O. Box 62, Oak Ridge, TN 37831; prices available from (615) $576-8401$.

Available to the public from the National Technical Information Service, U. S. Department of Commerce, 5285 Port Royal Rd., Springfield, VA 22161. 
The Implementation of

Ion Exchange Technology

in the

Pretreatment of Soluble HLW

Feed to the DWPF 
Acknowledgements:

This report was prepared by the members of the WSRC Team assembled to technically assess the application of ion exchange technology for the processing of the HLW feed to the DWPF. The members of the team are:
J. M. Pope
E. F. Duhn
J. P. Bibler
M. D. Boersma
J. R. Fowler
R. A. Jacobs
S. Kodali
M. C. Thompson

\author{
Chairman \\ Co-Chairman \\ IWT \\ DWPT \\ DWPF \\ DWPT \\ E\&PD Systems Engineering \\ CTS
}

On two occasions the technical content of the report underwent intensive scrutiny by a panel of outside experts. In carrying out their review these outside experts made a significant contribution to this report. For this they are recognized. They are:
W. B. Barton
L. A. Bray
D. E. Carl
W. Greenaway
W. L. Wilkinson

WHC

PNL

WVDP

BSPI

Consultant (Co-Chairman. British Nuclear Forum) 
IX Technology Assessment Report

WSRC-RP.92-1093

ION EXCHANGE TECHNOLOGY ASSESSMENT REPORT OUTLINE

EXECUTIVE SUMMARY

1. INTRODUCTION

1.1 CHARTER

1.2 BACKGROUND

1.3 PROCESS DESCRIPTION

1.4 REFERENCES

2. CRITERIA/DESIGN BASES

2.1 ION EXCHANGE FEED AND PRODUCT CHARACTERISTICS

2.1.1

2.1 .2

SUMMARY

2.1 .3

KEY REQUIREMENTS FOR FEED TO $Z$ AREA

2.1 .4

ION EXCHANGE FEED CHARACTERISTICS

DWPF FEED ACCEPTANCE CRITERIA

2.2 OPERATIONAL REQUIREMENTS

2.3 REFERENCES

3. ASSESSMENT AND SELECTION OF MEDIA AND FLOWSHEETS

3.1 CESIUM ION EXCHANGE

3.1 .1

3.1.2

INORGANIC ION EXCHANGERS

ORGANIC ION EXCHANGERS

3.2 MERCURY ION EXCHANGE

3.3 SR/PU ION EXCHANGE

3.4 SELECTION OF MOST PROMISING FLOWSHEETS

3.4.1 INTRODUCTION

3.4.2 CASE 18 - Organic Resin, Once Through with TP-207

3.4.3 CASE 3B - Zeolite Resin @ 100 C

3.4.4 CASE 4. Organic Resin with Acid Elution and Secondary Dlaposal of Resin

3.5 SELECTION OF MOST PROMISING FLOWSHEETS

3.5.1

3.5.2

3.5 .3

3.5 .4
INTRODUCTION AND SUMMARY

CASE 1B

CASE 3B

CASE 4 
IX Technology Assessment Report

WSRC-RP-92-1093

4. DEVELOPMENT PROGRAM
4.1 TECHNICAL ISSUES AND UNCERTAINTIES
4.2 SCOPE, SCHEDULE, MANPOWER, WHERE

5. PROCESS IMPLEMENTATION
5.1 REGULATORY REQUIREMENTS
5.2 SCHEDULE
5.3 IDMS AVAILABILITY
5.4 SAFETY

6. CONCLUSIONS AND RECOMMENDATIONS
6.1 IX BACKGROUND
6.2 IX PROCESS TECHNOLOGY
6.3 IX PROGRAM DEVELOPMENT
6.4 PROGRAMMATIC INTERFACES
6.5 RECOMMENDATIONS

\begin{abstract}
APPENDIX A - WASTE CHARACTERISTICS APPENDIX B - CONCEPTUAL FLOW DIAGRAMS AND FLOWSHEETS APPENDIX C - IMPACTS OF ION EXCHANGE PROCESS ON WASTE ACCEPTANCE PROGRAMS

APPENDIX D - PROCESS UNCERTAINTIES AND OPPORTUNITIES APPENDIX E - IX PROCESSING OF WASH AND RECYCLE STREAMS
\end{abstract}


IX Technology Assessment Report

WSRC-RP-92-1093

\section{EXECUTIVE SUMMARY}

In the execution of its charter, the SRS Ion Exchange Technology Assessment Team has determined that ion exchange (IX) technology has evolved to the point where it should now be considered as a viable alternative to the SRS reference ITP/LW/PH process.. The ion exchange media available today offer the ability to design ion exchange processing systems tailored to the unique physical and chemical properties of SRS soluble HLW's. The technical assessment of IX technology and its applicability to the processing of SRS soluble HLW has demonstrated that IX is unquestionably a viable technology. The unknowns are few. This fact is reflected in the size and duration of the development program described in Section 4.2 which could be more aptly described as a proof of concept program. The proposed system offers a degree of operational flexibility unobtainable in a SRS HLW process based on chemical treatment while producing a feed stream to the DWPF free of benzene and other hazardous and complex hydrocarbons, and free of the alkalis that, in sufficient concentrations, could be deleterious to glass quality and, thus limit waste loading. The SRS issues are not technology related; they are related to cost, schedule and tank farm programmatic issues. However, given the promise of technology, it is recommended that an engineering/economic evaluation of the proposed IX system be performed on an accelerated basis to establish the cost of proceeding with IX as a backup or as a second generation technology to ITP/Late Wash in conjunction with commencing the development program. SRS is uniquely qualified to lead this development program in conjunction with PNL, WH, and other DOE contractors.

Key to the design of an ion exchange processing system is the demonstrated ability of the ion exchange media selected for a particular process to consistently sorb specific ions over a variable salt solution feed concentration range and feed rate, preferably without chemical adjustment of the feed stock and with minimal degradation of the exchange media. A design that achieves these performance objectives at SRS offers efficiencies to be derived from operational flexibility and simplicity with little or no downstream impacts to the DWPF or to the production of saltstone. The ion exchange process system design proposed in this report would not produce benzene as a side product. The cesium eluted from the resin for vitrification would be more compatible with the glass than that produced by the in-tank precipitation/late wash (ITP/LW) process because of the insignificant concentrations of alkali species, sodium and potassium, and boron in the feed stream to the melter. This could result in higher waste loadings in the glass as well as a faster salt solution/saltstone workoff rate. Finally, the proposed IX process is more efficient as it requires approximately $15 \%$ less process water as compared to the ITP/LW process (Section 3.4).

A fairly comprehensive development program designed to achieve an orderly evolution of the process from laboratory bench scale testing to an integrated process in an engineering test facility will be required to confirm the performance capabilities of the candidate process. A development program is described in Section 4 of this report. The development program derives support from Westinghouse Hanford and PNL concurrent with the utilization of the extensive laboratory and test facilities available at SRS to conduct the required design development and process verification testing. The development described herein is estimated to require a period of 39 months the last 19 of which would be devoted to integrated IDMS testing at SRS assuming no IDMS schedule conflicts. The estimated cost of the development phase of the program is $\mathbf{\$ 7 . 9 M}$; the estimated cost of the process verification runs proposed for the IDMS is $\$ 10.8 \mathrm{M}$.

The success of any ion exchange process is keyed to the selection of the ion exchange media. For the SRS $\mathrm{HLW}$, the IX media selected must be capable of sorbing $\mathrm{Cs} 137$ from a $\mathrm{pH}>13$ soluble salt solution containing concentrations of aluminum and sodium salts that are orders of magnitude higher than the concentration of cesium in solution. The solution pH cannot be adjusted below pH 12 because the aluminum salt would form an insoluble aluminum hydroxide precipitate that is difficult to filter from solution. The high sodium concentration in the solution can also compete for exchange sites on the $I X$ media, significantly altering the cesium sorption performance of the media. For this reason a survey of 
candidate ion exchange media was performed (Section 3). The salt solution pH limitation effectively eliminated the zeolites because of media dissolution concerns. Based on the survey it was concluded that the SRS resorcinol/formaldehyde resin, which has been independently demonstrated by PNL and ORNL researchers to have superior cesium sorbing properties, is the IX medium upon which the SRS HLW processing system described herein is based.

The proposed IX system design includes two tank farm salt solution receipt tanks into which sodium titanate would be added to sorb plutonium and strontium. The insoluble titanate would be filtered in a backwashable filter; the filtrate would be pumped to the cesium ion exchange columns. It is proposed that the system be designed with two cesium ion exchange columns in series, the first serving as the principal cesium removal column while the second column would serve as a backup to cesium breakthrough in the first column, and a third standby column. On exhaustion of the principal exchange column it would be removed from service, the backup would become the principal column and the spare would become the backup column. Once the columns have been realigned and placed in service, the cesium sorbed on the column removed from service would be eluted from the ion exchange resin with either nitric or formic acids followed by a resin reconditioning step using sodium hydroxide. Nitric acid is the preferred eluant candidate; it would be most compatible with the ITP/LW nitric acid flowsheet. The eluted cesium would be transferred to the DWPF feed tank for eventual vitrification. The proposed design is based on a column of resin being in service for six cycles. After the sixth cycle the resin would undergo a final elution step to remove the sorbed cesium and would then be transferred to a hold point for final disposition. Based on the reported efficiencies achieved in the elution of cesium from the resorcinol resin, it is projected that the "spent" eluted resin could be drummed and stored as low level waste thus ayoiding additional duty on the vitrification process. The sizing of the cesium IX columns would be based in part on optimal throughput before exhaustion and safety requirements.

The salt solution exiting the cesium ion exchange columns would pass through a backwashable filter designed to remove resin fines prior to being collected in a pair of holdup tanks sized to accommodate DWPF and saltstone planned shutdowns. The capability to monitor the cesium content of the processed salt solution in these tanks would also be provided. Holdup tanks are required because the IX system is proposed to operate as essentially a continuous process.

Under consideration is the inclusion of a mercury ion exchange system downstream of the aforementioned holdup tanks. This system would be similar in design to the cesium IX system, however, it would not include the elution feature of the cesium IX system. The resin would be discharged to waste upon exhaustion. The spent resin would be dewatered, packaged and stored as nonhazardous, low level waste. Available data suggests that the mercury content of the treated effluent from the cesium IX columns would be at or below the mercury limit for feed to saltstone. A substantial reduction in the overall cost of the system would be realized through the elimination of the need for a mercury processing capability if the data continues to support its elimination.

Addressed to a limited degree is the processing of the in-tank the precipitate slurry from ITP processing. Although recognized by the Team that dissolution of the precipitate with $m \cdot$ pyrol, an organic solvent, and subsequent sorption of the cesium on an IX resin was possible, it was concluded that too many uncertainties related to the organic solvent present in the effluent exist at this time to make a judgment as to the process' potential for success. A development program would be required to address known uncertainties. For this reason the Team thought it appropriate to give consideration to the application of the Late Wash technology for the processing of the ITP precipitate.

Described above is the IX process proposed for the treatment of SRS HLW salt solution. Support systems such as a resin loading system, acid and caustic storage, mixing and transfer systems to provide elution capability, spent resin transfer systems, resin dewatering and drumming facilities, an assured source of power, and a process control facility will also be required. A more detailed system description and process diagrams are presented in Section 2.2. The cost of the IX system will be driven 
IX Technology Assessment Report

WSRC-RP-92-1093

by the type of building facility selected and the tankage required. The cost of these items could exceed $80 \%$ of the project TEC. The cost of the IX process hardware including piping, pumps, valves, instrumentation, etc. is estimated at $<20 \%$ of the TEC.

A project of this size would require implementation of all applicable DOE Orders. Therefore, given the most optimistic schedule (example LW) it is estimated that the IX system could not be in service before 1997, more realistically late 1999 assuming a normal project schedule. Given this lead time and the pressing need for volume capacity in the tank farms, the existing SRS DWPF startup strategy plan process the stored HLW should be implemented. 


\subsection{Introduction}

A task team was chartered to evaluate the technology of ion exchange and its potential for replacing the present In-Tank Precipitation and proposed Late Wash processes to remove Cs, Sr, and Pu from soluble salt solutions at SRS. This report documents the ion exchange technology assessment and conclusions of the task team.

\subsection{Charter}

The following is the charter for the ion exchange technology assessment task team. The sections in this report in which each of the actions expressed in the carter are addressed are identified in parenthesis.

- Develop criteria for selection of an ion exchange (IX) media for treatment of SRS high level waste (HLW) (Section 2.0)

- Assess IX media for application in the treatment of SRS HLW (Section 3.0)

- Develop a short list of IX media systems offering the most potential (Section 3.0)

- Develop a list of key technical issues that would have to be resolved to support the design and subsequent startup of an IX system (Section 4.0)

- Generate a strawman development program that would be required to support a CDR and subsequent project through startup (Section 4.0)

- Produce an IX process development logic diagram showing key decision points (Section 4.0)

- Prepare a strawman SRS HLW IX system process flowsheet (Section 2.0)

- Prepare an IX system development program schedule and cost estimate (Section 4.0)

- Maintain a close interface with the Programmatic Assessment Team for the purpose of ensuring that the tank farm and DWPF technical requirements have been addressed (Section 6.0)

- Document the assessment process and results/product(s) in a repont no later than 9/15.

\subsection{Background for LW/ITP}

The program for treatment of radioactive wastes stored at the Savannah River Site requires treatment of two waste streams; the sludge stream which contains most of the radionuclides and the salt stream which contains the soluble salts including most of the cesium and a very small fraction of the strontium and plutonium. The cesium, strontium and plutonium are removed from the salt stream, mixed with sludge, and vitrified into borosilicate glass for storage in an offsite Federal repository. The decontaminated salt stream is mixed with cement and other components and disposed as low-level waste in near surface vaults. This low-level waste, called saltstone, is permitted as an NRC Class C waste. However, the South Carolina Department of Health and Environmental Control (SCDHEC) must be notified if the waste is to exceed NRC Class A criteria.

DWPF is scheduled to start radioactive operation in June, 1994. The original DWPF flowsheet as shown in the EIS used ion exchange processes for removal of $\mathrm{Cs}$ and $\mathrm{Sr} .1$ Cesium removal from the soluble salts was accomplished by ion exchange with a commercial organic Duolite resin. The Cs was eluted from the Duolite resin and readsorbed on a zeolite. The zeolite with adsorbed Cs was sent to vitrification. After Cs removal, Sr was adsorbed on a commercial organic Amberlite resin, eluted, and sent to be vitrified with the sludge and Cs-zeolite. The total amount of aluminum in the sludge and zeolite controlled the quantity of glass made in this flowsheet. Removal of aluminum from the sludge would make zeolite the control for the quantity of glass. 
IX Technology Assessment Report

WSRC-RP.92-1093\%

In the mid 1980's, the process for Cs removal was changed to the In-Tank Precipitation (ITP) process in which $\mathrm{Sr}$ and $\mathrm{Pu}$ are removed first by adsorption on monosodium titanate (ST), then sodium tetraphenylborate (NaTPB) is added which precipitates $C s$ and $K$. The entire process is accomplished in existing waste tanks so the size of the DWPF canyon was reduced, resulting in lower capital cost. A simplified process flowsheet is shown in Figure 1.2-1. In the initial ITP process, the slurry of ST and Cs/KTPB resulting from precipitation is filtered and stored in a second tank until required in DWPF. In DWPF, the Cs/KTPB is hydrolyzed in the Precipitate Hydrolysis Reactor (PHR) to solubilize Cs and remove benzene from TPB before feeding to the melter. The hydrolyzed solution and ST is transferred from the PHR to the Sludge ReceipUAdjustment Tank (SRAT), mixed with sludge and transferred forward to vitrification. The benzene formed during hydrolysis is separated and sent to the incinerator.

By 1988, research on the process had shown that nitrite ion, added to the stored slurry to prevent corrosion of the carbon steel storage tank, caused formation of undesirable organic compounds (biphenyl, terphenyl, aromatic amines, and other high-boiling organics) during precipitate hydrolysis. A 1988 technology decision to address the organics problem led to the selection of the process in which hydroxylamine nitrate (HAN) is added during precipitate hydrolysis to react with nitrite. The Late Wash (LW) process in which the Cs/KTPB/ST slurry is washed with water to lower the nitrite concentration prior to transfer to precipitate hydrolysis was the second choice. The HAN process was selected at that time because of lower cost and more rapid implementation.

In August, 1991, Integrated Demonstration Melter System (IDMS) tests with simulated sludge including noble metals and with aqueous phase from precipitate hydrolysis resulted in accumulation of $\mathrm{NH}_{4} \mathrm{NO}_{3}$ and aromatic amines in the IDMS offgas system especially the instrument lines. The aromatic amines (from reactions of nitrite with TPB and benzene during precipitate hydrolysis) were carried into the offgas system during evaporation in the Slurry Mix Evaporator (SME). Ammonia was found to come from several sources with about $80 \%$ coming from hydrolysis of excess HAN during precipitate hydrolysis. Hydrolysis of Cs/KTPB involves addition of formic acid to adjust the $\mathrm{pH}$ and addition of $\mathrm{Cu}$ (II) to catalyze the hydrolysis reaction. However, when the aqueous phase from precipitate hydrolysis was transferred to the SRAT, the noble metals in the sludge catalyzed the destruction of formic acid varying the $\mathrm{pH}$ such that $\mathrm{NH}_{3}$ gas was volatilized into the offgas system where it reacted with $\mathrm{HNO}_{3}$ vapors to deposit $\mathrm{NH}_{4} \mathrm{NO}_{3}$. Figure $1.2-2$ shows where the materials would accumulate in the DWPF offgas system. Although the problem can be handled, the downtime required to clean the offgas system would reduce DWPF capacity and the additional water recycled to the tank farm for evaporation would strain tank farm capacity to handle all recycle liquids.

A task team was formed in November, 1991 to recommend ways to reduce the nitrite concentration in the feed to the PHR. The task team chose radiolytic destruction of nitrite as the first choice with Late Wash as the backup. In February, 1992, laboratory studies showed that the rate of radiolysis is 100 low for use in the process. A program was instituted which demonstrated the Late Wash process at the laboratory scale by May 15, 1992. A conceptual design effort was started simultaneously and a cost estimate was ready by July 1, 1992. Figure 1.2-3 shows the Late Wash schematic.

During the spring of 1992, work started on a sludge only flowsheet as a contingency if Late Wash could not be ready by June, 1994 when radioactive operations are scheduled to start in DWPF. The sludge only process will vitrify the sludge without any of the Cs or Sr from the soluble salt solution. The sludge only process is an alternative evaluated in the DWPF EIS. 1 
IX Technology Assessment Report

WSRC-RP-92-1093

Figure $1.2 \cdot 1$

DWPF Process Flowsheet

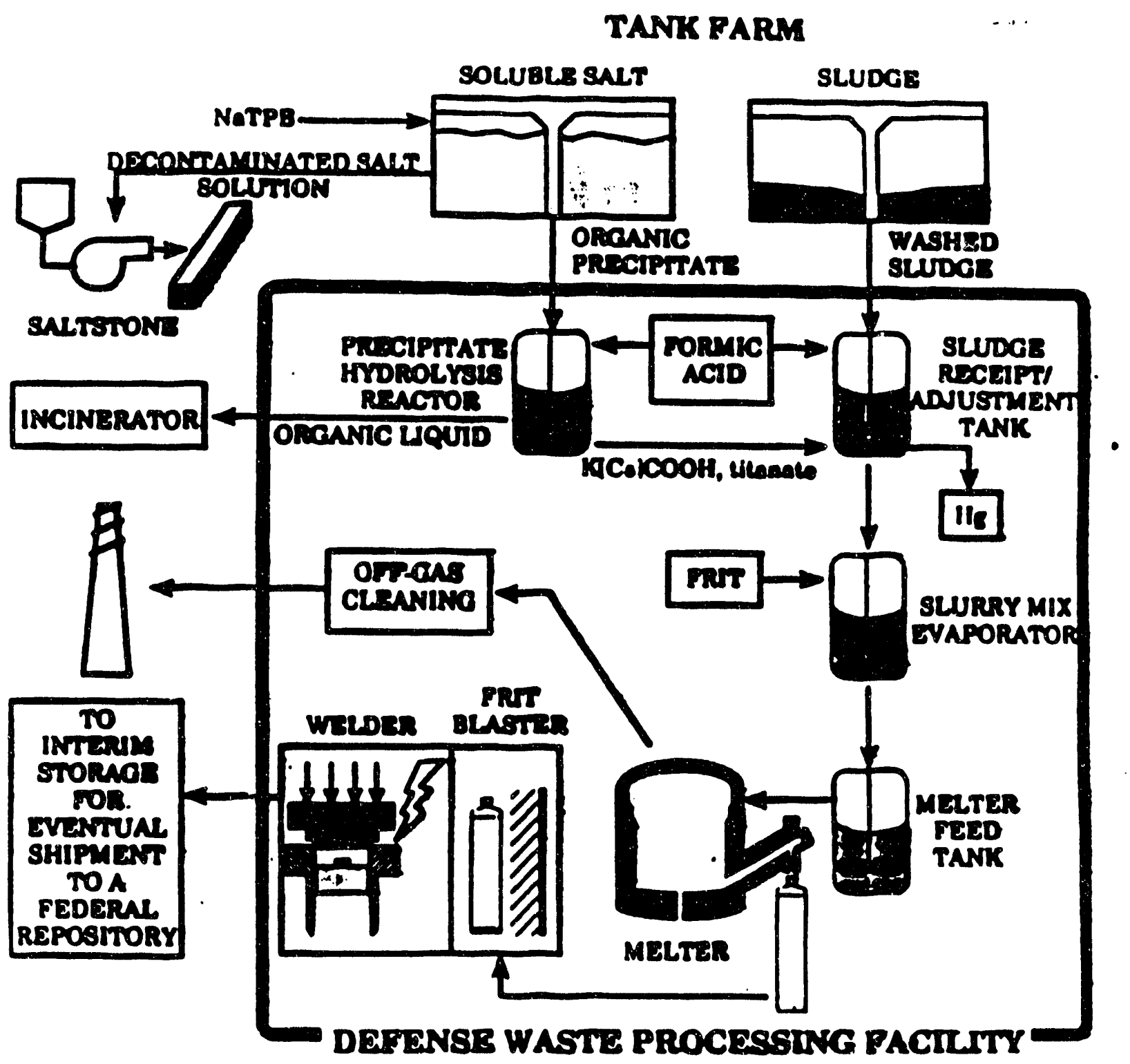


IX Technology Assessment Report

WSRC-RP.92-1093

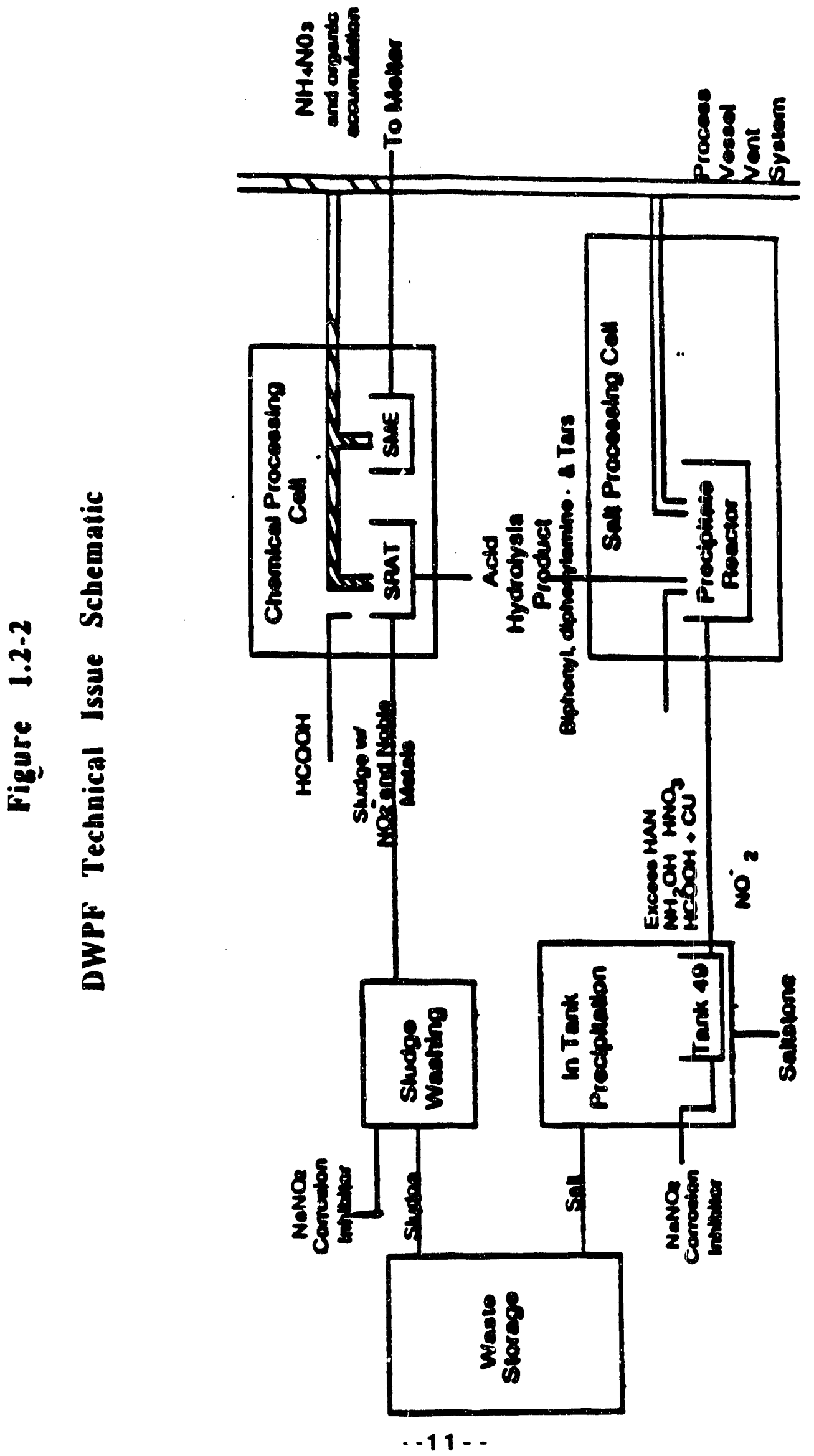


IX Technology Assessment Report

WSRC-RP-92-1093

Figure 1.2.3

Late Wash Schematic

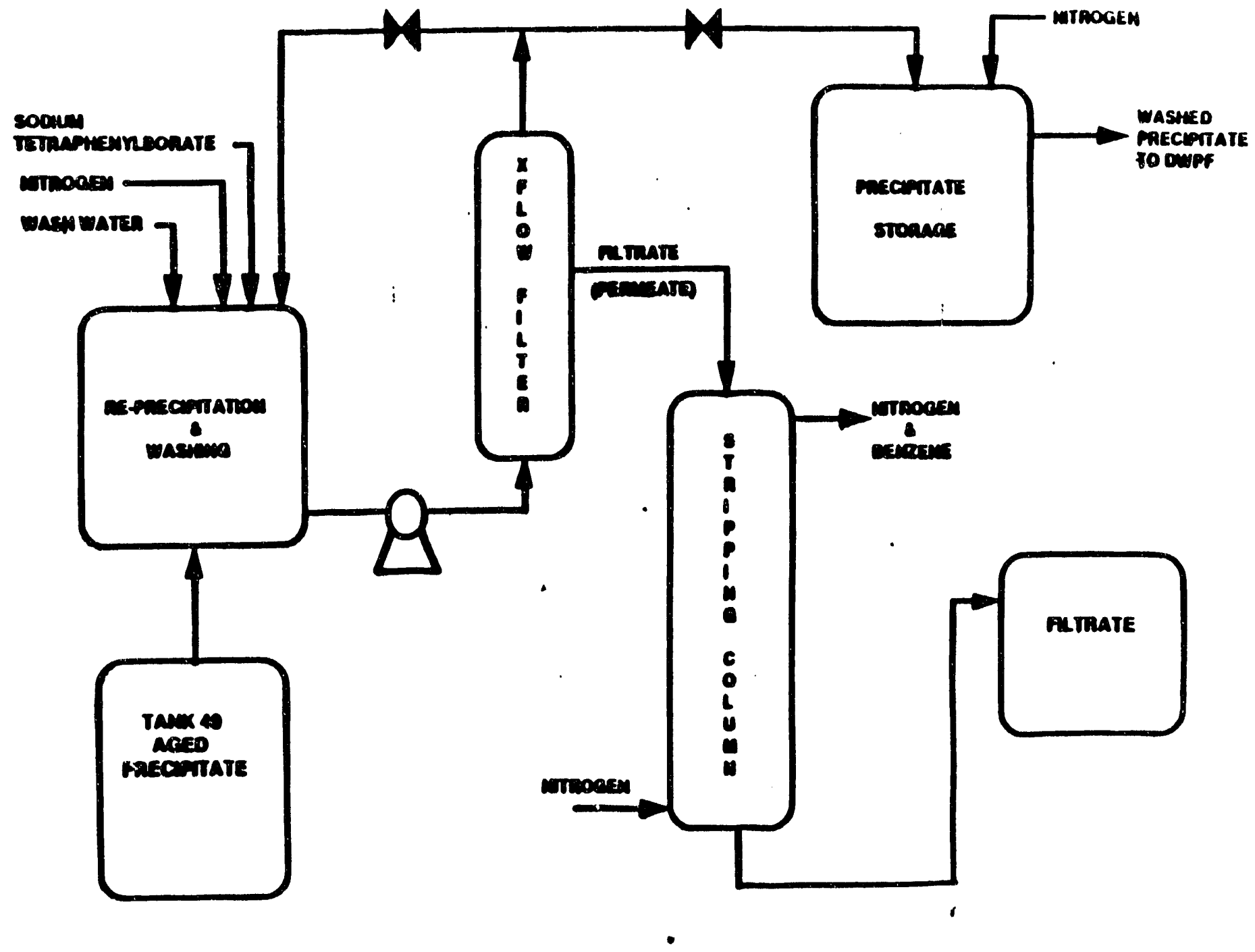




\subsection{Proposed Reference Ion Exchange Process}

The proposed reference ion exchange process is shown in Figure 1.3-1. Salt solution is transferred from the salt tanks to a feed makeup tank where sodium titanate is added to adsorb $\mathrm{Sr}$ and $\mathrm{Pu}$ as in the ITP process. The solution is filtered to remove the titanate and any sludge solids which may be present from dissolution of salt cake. Cesium is adsorbed from the filtrate onto resorcinol-formaldehyde ion exchange resin and washed to remove residual salt solution. Cesium is eluted from the resorcinolformaldehyde resin with acid, combined with the titanate/sludge solids and transferred to DWPF. In the DWPF, the eluate with titanate/sludge solids is mixed with sludge from Extended Sludge Processing and made into glass. The resorcinol-formaldehyde resin is conditioned with base prior to each loading/elution cycle. Spent resorcinol-formaldehyde resin is eluted further to remove residual radioactivity, washed, dewatered, and packaged for interim storage pending incineration or burial as low-level waste, dependent on permitting.

Effluent and washes from Cs adsorption are filtered again prior to removal of $\mathrm{Hg}$ on $\mathrm{GT}-73$ ion exchange resin. Effluent and washes from the $\mathrm{Hg}$ removal column are sent to Z-Area for disposal as saltstone. The GT-73 resin loaded with $\mathrm{Hg}$ is washed, dewatered, and packaged for burial as a nonhazardous, low-level waste. The waste is non-hazardous because the $\mathrm{Hg}$ is chemically bound to $\mathrm{S}$ in the resin and cannot be leached from the resin. $2-4$

However, ion exchange removal of $\mathrm{Hg}$ may not be required for disposal in saltstone, based on current limits and expected concentrations of $\mathrm{Hg}$ in the HLW salt solution.

If ITP is operated to maintain tank farm operations until ion exchange processing of salt solution can be started, 1 million gallons of 10 wt\% potassium (with cesium) tetraphenyiborate from Tank 49 will be dissolved in an aqueous-miscible organic solvent and fed to the IX prefilter. IX operations will proceed as before. The decontaminated effluent from $I X$ will have a high organic content and probably will be unsuitable for Saltstone. Treatment by incineration or another oxidation process is envisioned.

Details on the selection of the proposed reference process are provided in section 3.

\subsection{References}

1. DOE/EIS-0062, Final Environmental Impact Statement, Defense Waste Processing Facility, Savannah River Plant, Aiken, SC, February, 1982.

2. Bibler, J.P. and Wallace, R.M., "Mercury Removal from Supernate Using lon Exchange", DPST-84-848, October 30, 1984.

3. Bibler, J.P., "EP-Toxicity Test of Saturated GT-73 Resin and Resin in Grout", DPST85-446, April 24, 1985.

4. Bibler, J.P., "TCLP Test Results for $\mathrm{Hg}, \mathrm{Cr}(\mathrm{III})$, and $\mathrm{Pb}$ on GT-73 Cation Exchange Resin", DPST-87-811, Nov. 13, 1987. 


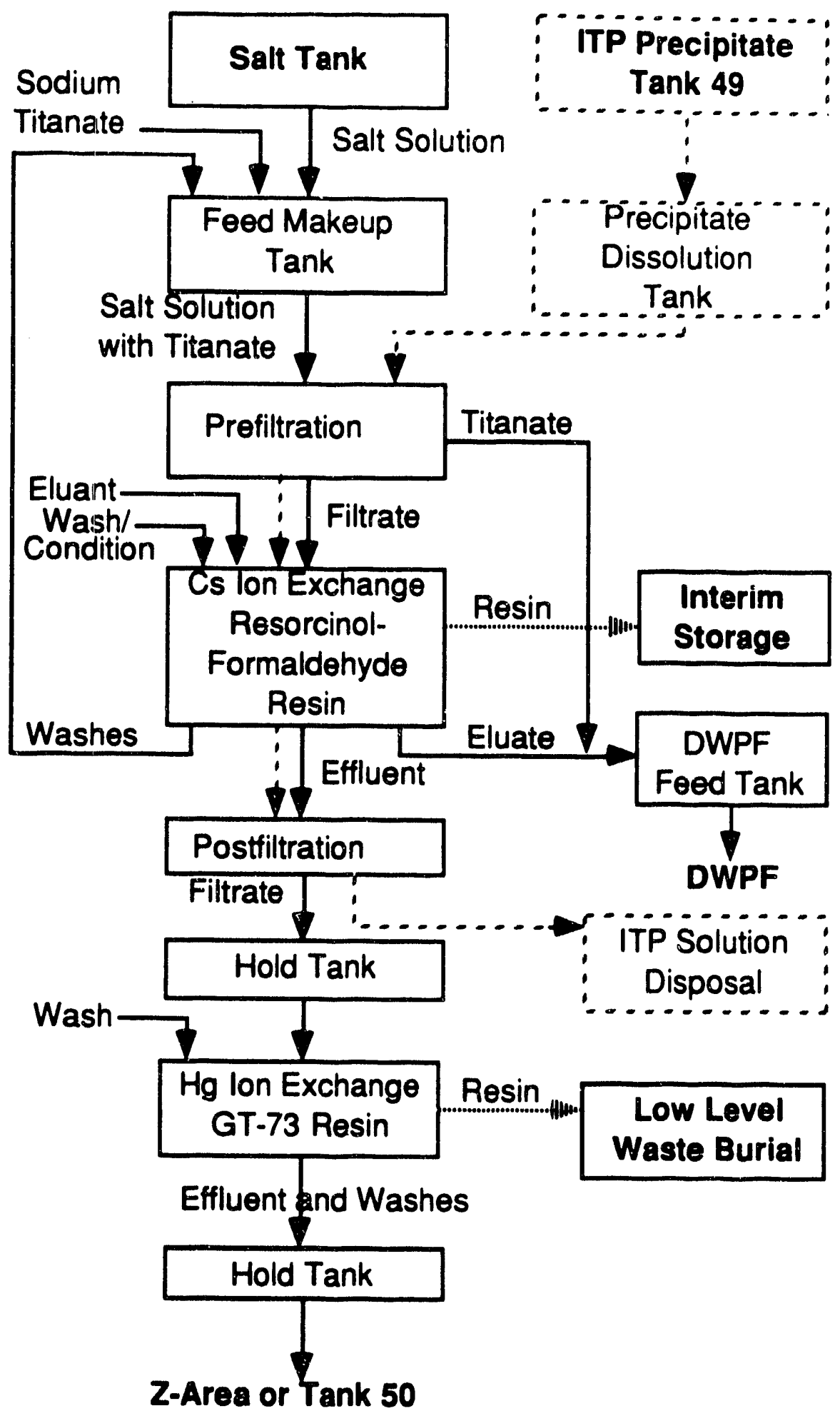


IX Technology Assessment Report

WSRC-RP-92-1093

\subsection{CRITERIA/DESIGN BASES}

\subsection{Ion Exchange Feed and Product Characteristics}

\subsubsection{Summary}

The feed to ion exchange is highly variable in the concentrations of the elements and isotopes of concern to the DWPF and Z-Area. The present design and operations in DWPF and Z-Area are based on an inTank Precipitation Process, in which HLW salt solutions are chemically treated to reduce the levels of Cs-137, Sr-90 and alpha activity. The stream containing Cs, Sr, and alpha activity must meet the criteria for acceptance in DWPF to make glass. The decontaminated salt solutions must be within the levels specified for safe operation and saltstone disposal in Z-Area. Based on the projected wastewater composition to be sent to Z-Area, saltstone has been formulated to meet long-term performance requirements for disposal of LLW specified in DOE Order 5820.2A. ${ }^{1}$ The ion exchange process must yield products which meet the same criteria as the existing process.

The product containing Cs, Sr, and Pu from the proposed reference ion exchange process has no major adverse impact on DWPF. In fact, DWPF feed from ion exchange will remove the need for some feed criteria and reduces the quantity of alkali metals and volatile organics.

Based on knowledge of the HLW compositions and the ETF (Effluent Treatment Facility) process, expected concentrations of key contaminants in feeds from ITP and ETF have been projected. These are compared to Z-Area Waste Acceptance Criteria (WAC) and ALARA guides in Appendix A, Table 1.2 The process used to decontaminate waste is immaterial to Z-Area processes and disposal, providing Z-Area Waste Acceptance Criteria (WAC) are met. (Appendix A, Table 2) Thus, ion exchange will have no impact except to decrease the quantity of saltstone made by $15-20 \%$. Appendix A contains an expanded explanation of the data and its sources.

\subsubsection{Ion Exchange Feed Characteristics}

\subsubsection{F Area and $H$ Area Composite Solids}

The chemical and radiochemical composition of F-Area and $\mathrm{H}$-Area soluble waste (Appendix A, Table 3) was estimated to serve as a basis for the design of the DWPF and related in-tank processing.

Methodology used to obtain the compositions are summarized in the references. For nuclides that little experimental data exists or that Waste Management Operations (WMO) does not maintain inventories on, a hypothetical production mix through Separations and an assumed split between soluble and insoluble fractions of the waste is used to estimate concentrations. ${ }^{3}$ The projected radionuclide content in soluble HLW is based on an assumed age of 15 years and a perfect blend of all salt solids. These estimates served as the design basis for the Z-Area process. The concentration of shorter-lived species (e.g. Co-60) shown in the table are higher than would be expected in older waste stored in the Tank Farms (average age $>15$ years).

WMO maintains inventory records on Cs-137, Ru-106, and Sr-90 in soluble and insoluble fractions of the waste. 4 These records were used to project the concentration of these 3 nuclides in the overall composite salt solution from the inventory. (Appendix A, Table 3) These estimates are conservative, since at least a portion of these nuclides are associated with insoluble solids that are a component of the soluble waste inventory.

To estimate the dissolved salt solution composition, an overall average density of 1.30 and 35 wt\% soluble solids was assumed. These values approximate the salt solution properties observed during salt 
dissolution operations in Tanks 19F, 20F, and 24H.3,5,6 Based on the current waste inventory and these assumed solution properties, $70-75$ million gallons of salt solution will be generated during dissolution operations that must be decontaminated before disposal in Z-Area.

\subsubsection{Composition of First Tanks to be Processed}

Based on space limitations of the waste evaporator systems used in the F/H Waste Tank Farms, salt removal must be done in a specific sequence to enable the Tank Farms to gain salt storage space in evaporator systems critical to continuing operation of other SRS facilities. The projected removal sequence is Tank $41 \mathrm{H}$, Tank 25F, Tank $29 \mathrm{H}$, and Tank $28 \mathrm{~F}$ for the first four salt tanks. The salt in Tank $41 \mathrm{H}$ must be dissolved, decontaminated and sent to Z-Area before S-Area can begin radioactive operations. Otherwise, space will not be available in the Tank Farm for the recycle stream from $S$. Area. Salt must be removed from the other tanks to provide salt storage for the other waste evaporator systems. Otherwise, the evaporators will be unable to continue operation. Projected composition of the salt solutions from these four tanks are shown in Table A-4. These compositions were estimated based on the history of waste types that were evaporated to fill these tanks. ${ }^{7}$

The following mole ratios were obtained from the cata in Table 4 Appendix A. Although these

\section{Mole Ratio}

$\mathrm{Na} / \mathrm{Cs}$

$\mathrm{K} / \mathrm{Cs}$

\section{Maximum}

$>1,000,000$

2,500

\section{Minimum}

20,000

20

values are only for the first six tanks to be processed, the ranges are reasonable for all the lanks, i. e., mole ratios will vary by a factor of 50 to 100 between the maximum and minimum.

\subsubsection{Key Requirements for Feed to Z Area}

Decontaminated solutions from ion exchange must meet the limits set in the Waste Acceptance Criteria for feed solutions to saltstone. ${ }^{2}$ A regulatory condition of Z-Area permits specifies radionuclide limits promulgated by the NRC as the basis for disposal of Salistone. Disposal of saltstone that exceeds Class C limits as defined by the NRC cannot be placed in the Z-Area vaults. Furthermore, SCDHEC requirss that the DOE report any quantity of waste that exceeds NRC Class A limits. WSRC has adopted a long-term goal to maintain the overall average concentration of all saltstone sent to Z-Area vaults for disposal to be within the NRC Class A limits. This goal does not preclude disposal of some saltstone that exceeds NRC Class $A$ limits, providing the average concentration in all the waste is below the Class $A$ limit. DOE Order 5820.2A also specifies long-term performance goals for all LLW disposal sites, and this requirement limits the concentration of nuclides that are not normally considered to be significant radiological hazards. $1,8-12$

Based on analyses of soluble HLW waste and process history for the separation areas, $\mathrm{Cr}$ (as chromate) and $\mathrm{Hg}$ are the only two hazardous metals that are present in significant concentrations, relative to limits and ALARA guides. Both of these species are projected to be well within the WAC acceptance limits in HLW waste and are usually below the ALARA guide values. ${ }^{13,14}$ However, the ITP process, through reaction with tetraphenylborate, removes $\mathrm{Hg}$ from the HLW wastewater. Although the levels of $\mathrm{Hg}$ in untreated $\mathrm{HLW}$ soluble waste are sufficiently low to preclude $\mathrm{Hg}$ removal, an increase in the $\mathrm{Hg}$ concentration in Z-Area feeds relative to the ITP effluent could be interpreted by SCDHEC as a significant change in the waste composition that would require significantly more monitoring or control. 


\section{Technology Assessinent Report}

WSRC-RP-92-1093

Based on projected concentrations of radionuclides in the wastewater generated from soluble HLW, nuclides of concern for meeting feed specifications are Sr-90, Cs-137, and total alpha activity (principally due to Pu-238, minor contributions from Pu-239, $U$ isotopes, and Np-237). Sr-90 and total alpha activity are lowered by use of titanate as in ITP so the concentrations will be comparable. The following table shows the expected differences between feed streams from the two processes.

\section{Saltstone Feed Comparison Between ITP and Proposed Reference IX Flowsheet}

\section{Component}

Decon'd Salt Solution, gpm

Benzene, $\mathrm{mg} / \mathrm{L}$

Phenol, $\mathrm{mg} / \mathrm{L}$

Isopropanol, $\mathrm{mg} / \mathrm{L}$

Methanol, $\mathrm{mg} / \mathrm{L}$

Other Soluble Organics,

$\mathrm{Sr}, \mathrm{Ci} / \mathrm{L}$

Cs, CilL

Total Alpha, CV/L

$\mathrm{Hg}, \mathrm{mg} / \mathrm{L}$
ITP

14480

$<2$

TBD

5E-07

$1 E .05$

$1 E .06$

5E.02
IX

12406

0

0

TBD

6E.07

$<1 E-05$

1.2E-06

$<1 E-02$

Note that benzene which is limited for saltstone is not present with ion exchange. In addition, soluble organics such as phenol which are formed by radiolysis are greatly reduced. The table shows that the ion exchange product has the same or lower concentration for all the components important to saltstone. In addition, the volume of decontaminated salt solution sent to Z-Area is $15-20 \%$ less than for ITP. One cell of saltstone is made for each million gallons of salt solution. Thus, lower solution volume would reduce the quantity of saltstone by the same percentage $(15-20 \%)$.

\subsubsection{DWPF Foed Acceptance Criteria}

The feed acceptance criteria for DWPF as given in the draft DWPF Feed Acceptance Criteria do not significantly limit the ion exchange product stream. ${ }^{15}$ In lact, the feed to DWPF from the

DWPF Feed Comparison Batween ITP and

Proposed Reference IX Flowsheet ${ }^{2}$

\section{Component}

Salt Flow, GPH

TPB(all types), Ib/hr

Resin, Ib/hr

Potassium, lb/hr

Sodium, $\mathrm{lb} / \mathrm{hr}$

Total Alkali, lb-moles/hr

Titanium, Ib/hr

Boron, Ib/hr

Formic Acid, Ib/hr
ITP

754.3

47.03

0

5.63

2.43

0.249

0.849

1.53

21.4
IX

754.3
0
0
$0.63 \quad(a)$
$0.37 \quad(a)$
0.032
0.849
0.00

24.6 (b)

(a) Assumes 50-50 split of $\mathrm{Na}$ and $\mathrm{K}$ on resin.

(b) Assumes $1 \mathrm{M}$ formic acid to elute Cs from column. Value is zero if nitric acid is used. 
proposed reference ion exchange process is very similar to the aqueous product from precipitate hydrolysis except there is no boron, lower alkali content, and probably no volatile, flammable organics. This should result in an cperability enhancement of the DWPF processes. Several criteria potentially relating to the ion exchange product are given below.

\section{Affected Criteria}

- Volatile, flammable organics

\section{Comments}

Reviewed on a case by case basis. Cs/KTPB hydrolysis releases benzene. No flammable organics are present from $\mathrm{IX}$.

- Nitrite to precipitate hydrolysis IX removes this criteria.

- Total nitrite/nitrate to melter Limited by permitted NOx emissions. IX will send nitrite to saltstone instead of DWPF.

- Total Al, Fe, and alkali

- Cu solubility in glass

Affects glass liquidus. Less alkali going to DWPF because $K$ not absorbed by resin.

Amount depends on glass redox. IX eliminates problem because no Cu catalyst needed for hydrolysis.

- 1 wt \% TiO2 in glass

Same amount of TiO2 as for present process.

Additional feed criteria not presently specified, but which are potentially affected by ion exchange are shown below.

\section{Affected Criteria}

- Ionic organics in precipitate

\section{Comments}

Affect hydrolysis catalyst activity. Not a problem with IX.

The ion exchange process can actually be decoupled from the DWPF if capacity for storage of the product is incorporated in the design. An appropriately sized hold tank for ion exchange product is all that is required to decouple.

\subsection{Operational Requirements}

This section gives preliminary flow diagrams and operational requirements for the recommended reference process described in Section 1.3. It is intended to give a rough idea of the scope of facilities required. The process is divided into 7 natural segments. Diagrams show only major process vessels and flow paths, not instruments, valves, or many pumps. No diagram is given for the last segment, KTPB dissolution (transition process), nor for spent IX resin dewatering, packaging and storage.

\section{Eeod Makeup}

Salt solution feed will be prepared in one or more large steel tanks. An existing Type 3 waste tank may be used. From the IX processing standpoint, feed tankage must provide volume (time) for both batch makeup and IX feeding, which cannot occur simultaneously unless 2 tanks are 


\section{Technology Assessment Report \\ WSRC・RP.92-1093}

used. From the salt removal standpoint, a tank large enough to accept a full redissolved salt batch of about 500,000 gallons may be desired. An overall system engineering analysis is required to determine the optimum tank size and number. Two are shown in the diagram below. Feed makeup tankage must be doubled-shell (Type 3 equivalent).

A cold chemical sodium titanate (ST) slurry storage tank and delivery system - same as existing for ITP - is required. A small inorganic flocculent storage and delivery system is provided to enhance filtration of hydrated sludge. Process (inhibited) water is required for dilution. Resin transfer (slurry) water may provide part of this requirement.

The Feed Makeup Tank(s) must be agitated for good ST contact and for slurrying the ST out of the tank in $1 X$ feed.

Maximum temperature is $70^{\circ} \mathrm{C}$ for corrosion protection. Temperature limit may be lower because of feed pump cavitation considerations.

Salt solution/ST slurry will be fed to the IX prefilter at up to $150 \%$ of the required "averagen instantaneous rate. This sprint capacity will allow processing low-cesium salt at an accelerated rate, ultimately resulting in fewer DWPF glass canisters. Preliminary calculations indicate the maximum IX feed rate will be about $30 \mathrm{gpm}$. Pump may be "standard" (low shear not required). Note that feed makeup tankage must match this rate, as must salt removal capacity (not part of IX project).

\section{EEED MAKEUP DIAGRAM}

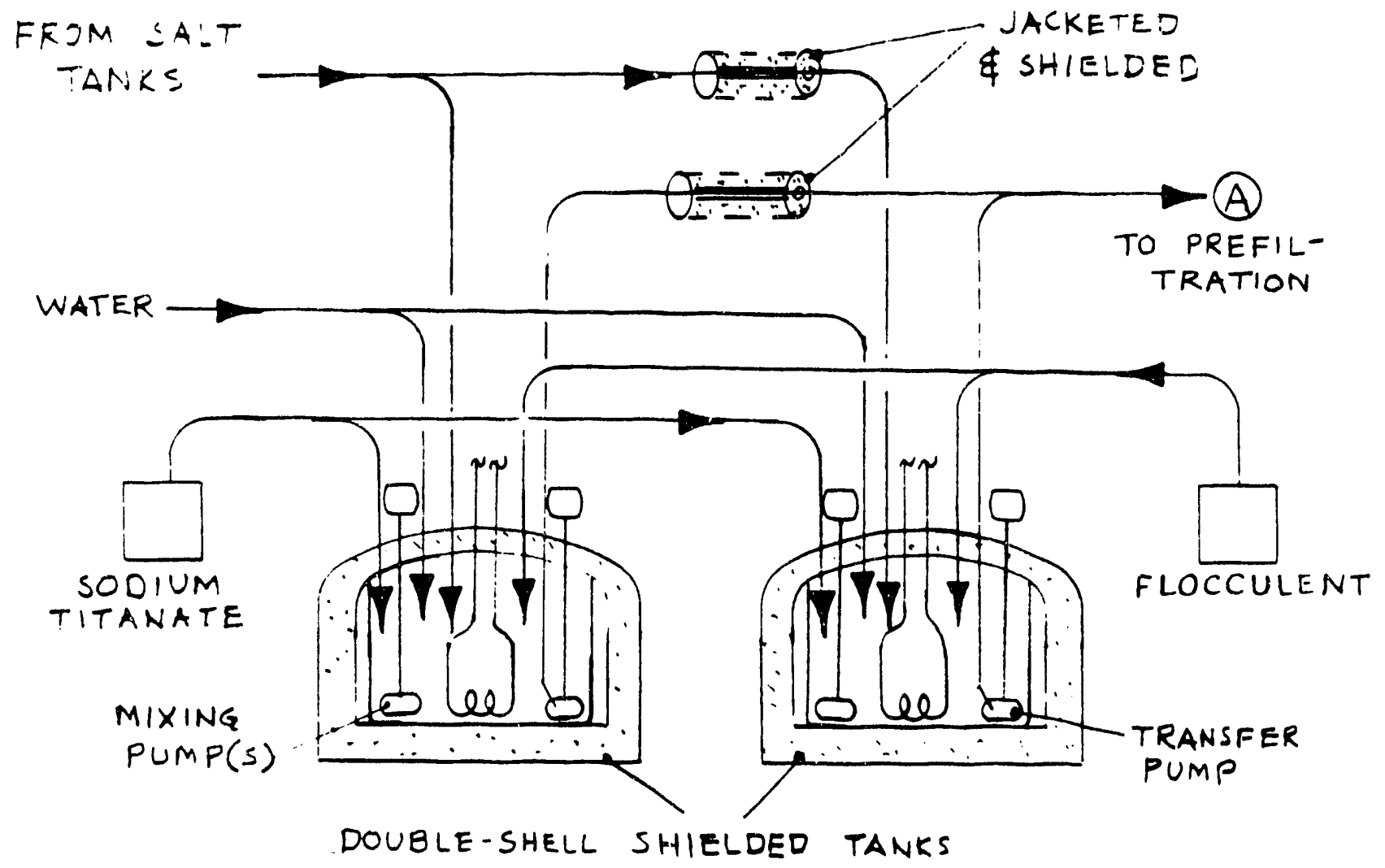




\section{Technology Assessmant Report \\ WSRC-RP-92-1093}

\section{Prefiltration}

A prefilter must be provided to remove ST and sludge. Pending more data, assume that sludge mass is up to twice the sodium titanate mass (expected to be much less most of the time, and could be more occasionally). Based on overall Sr/Pu DF considerations and assuming that all unfiltered ST fines proceed to Saltstone, prefilter must remove $98 \%$ of ST. Current ITP ST size specification is $<1 \%$ (mass) $<1$ micron; $<1 \%>35.5$ micron. Assume that a prefilter designed to remove ST particles in this size range will sufficiently remove sludge particles (flocculation will be used only if necessary).

Concentrated solids from the prefilter will be periodically pumped to the IX Eluate (DWPF Feed) Tank. Frequency of transfer will be determined not only by filter $\Delta P$, but also by batch modulation in the DWPF Feed Tank (titanate spikes to glass must be avoided). In the diagram below, two parallel sand filters are shown. One is filtering while the other is being backwashed or is idle. Flow to IX is therefore continuous. An engineering analysis may show that a single filter with a discontinuous but larger flow rate is less costly.

Prefilters and associated plumbing will contain full-strength salt and cesium levels (corrosion and shielding determinants). Filter surface and concentrate transfer system will contain more concentrated sludge and ST levels (criticality and hazard class determinants). If sand filter is used, provision must be made for sand loading, backwashing/fluidizing, and ultimate disposal. High pH of feed may limit "sand" choices.

\section{PREFHLTRATION DIAGBAM}

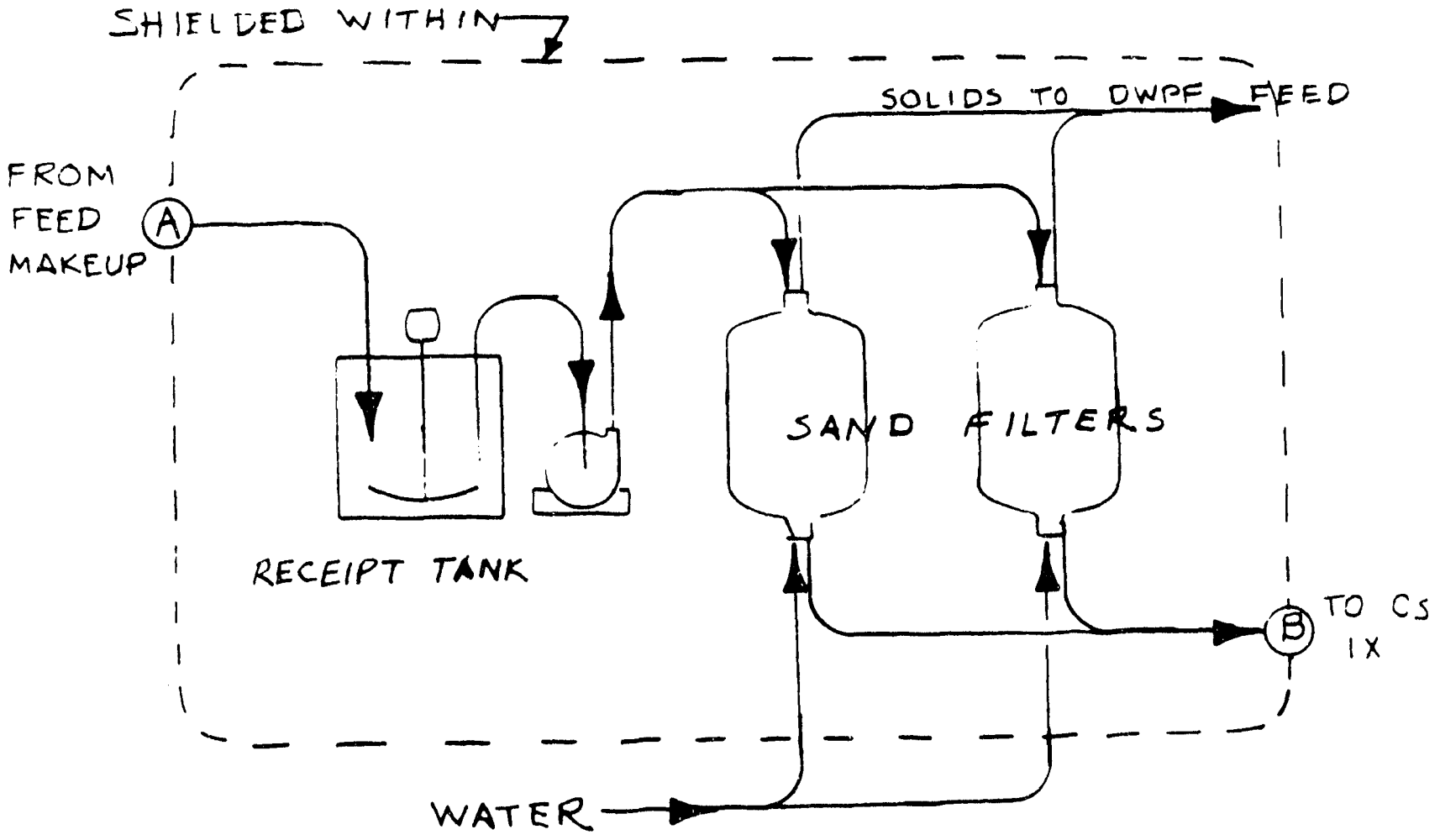




\section{Cesium Removal IX}

A 3-column system will be used. The first column (bed) receives fresh feed from the prefilter. Effluent from this column feeds the second "guard" column and then flows to the next process step, $\mathrm{Hg}$ removal. The third Cs column is being eluted, washed, and reconditioned - or loaded with fresh resin and conditioned - and placed in readiness to serve as next "guard" bed.

Column performance and incipient Cs breakthrough will be monitored by gamma counting. Before this measurement is made, the Ba-137m (not removed by $I X$ ) must be allowed to decay out. About $98.5 \%$ decay occurs in six half-lives, or 15 minutes. One way to achieve this without adding large decay chambers (375 gallons at $25 \mathrm{gpm}$ ) to each column is to sample the column effluent every 15 minutes and hold the sample 15 minutes before counting. When breakthrough of the first column is indicated, fresh feed is automatically diverted to the second (guard) bed and the third (regenerated) bed becomes the new guard bed.

Resin fines will be removed by a postfilter, either a single unit (possibly sand) in the common effluent line as shown, or a metal filter at the bottom of each column that can be cleaned simultaneously with elution or resin replacement. Very limited amounts of solids are expected. They will be added to the DWPF Feed (Eluate) Tank.

Decontaminated effluent from the Cs guard bed flows to a break tank (shown on $\mathrm{Hg}$ Removal Diagram) which is used for final verification of low activity level before the liquid flows to the unshielded mercury removal area.

Cesium will be eluted from a baded column with acid (type and strength TBD). About 10 bed volumes of acid will be needed. A (cold chemical) concentrated acid storage tank and a dilute acid makeup/feed tank are required. Tank sizes must be commensurate with overall IX attainment goal and supply reliability. For reference, a 30-day acid supply would be about 40,000 gallons as dilute acid. Acid will be pumped at a controlled rate through the column directly to the Eluate Hold/DWPF Feed Tank. Acid feed rate should be as slow as possible commensurate with the 3column cycle time. For example, if salt solution feed rate is $20 \mathrm{gpm}$ and the salt feed:eluate ratio is 20 (200 cbv:10 cbv), the acid feed rate must be greater than $1 \mathrm{gpm}$ to allow time for resin washing and conditioning. Elution at $2.5 \mathrm{gpm}$ may be reasonable. Eluate will be on-line monitored for $\mathrm{Cs}$ (Ba-137m is not a problem) to confirm when elution is complete.

Columns will be washed with 2-molar $\mathrm{NaOH}$ solution and water both before and after acid elution. A concentrated $(50 \%)$ and a dilute (2M) NaOH tank are needed. $2 \mathrm{M}$-caustic volume requirement per cycle is the same as for elution acid, but flow rate can be the same as salt solution feed rate. Washes will be sent to "existing" tanks - provided for other purposes.

After a number of load-elute cycles the spent resin will be replaced using water to slurry it in/out. Fresh resin dry storage, and a slurry makeup tank are required. The resin slurry makeup tank will be air-sparged for agitation, and a water overflow system will be used to remove fines. Columns will be loaded by gravity-drop from this tank, both to minimize water and to avoid attrition by mechanical pumping. Tank should be sized for one batch (column) at about 25 vol \% resin. Slurny water will be sent to "existing" tank - provided for other purposes. Spent resin will be decontaminated by extended elution, if necessary, either in place (in-column) or in a separate off-line washing vessel. This is a design tradeoff between cycle time and tankage. No additional chemicals, delivery systems, or spent decon solution tanks are needed. The spent, decontaminated resin will be drain-dried and drummed or otherwise packaged for interim storage and ultimate disposal. Provide 6-month storage facility. NOTE: CIF and Solid Waste Vault Disposal waste acceptance limits are currently being developer. 


\section{Technology Assessment Report}

WSRC-RP.92-1093

Interim vault limits for $\mathrm{Cs}-137$ are $30 \mathrm{Cl} / \mathrm{tt} 3$ (intermediate-level vaults) and $0.3 \mathrm{Ci} / \mathrm{tt} 3$ (low level). CIF limits are expected to be more restrictive due to high concentration in ash, which must be disposed of as solid waste. NRC Class C waste limit is $150 \mathrm{Ci} / \mathrm{ft} 3$.

Column design parameters ( $K d$, face velocity, resin size and $\triangle P, D F, \theta t c$ ) are provided elsewhere. Columns shall have up to $50 \%$ freeboard for resin expansion and to maintain a liquid head over the resin. Column sizing is a design function. In general, columns should be large to minimize cycling. Size may be limited by building space or by safety (radioactivity and heat) considerations.

\section{CESIUMONEXCHANGE DIAGBAM}

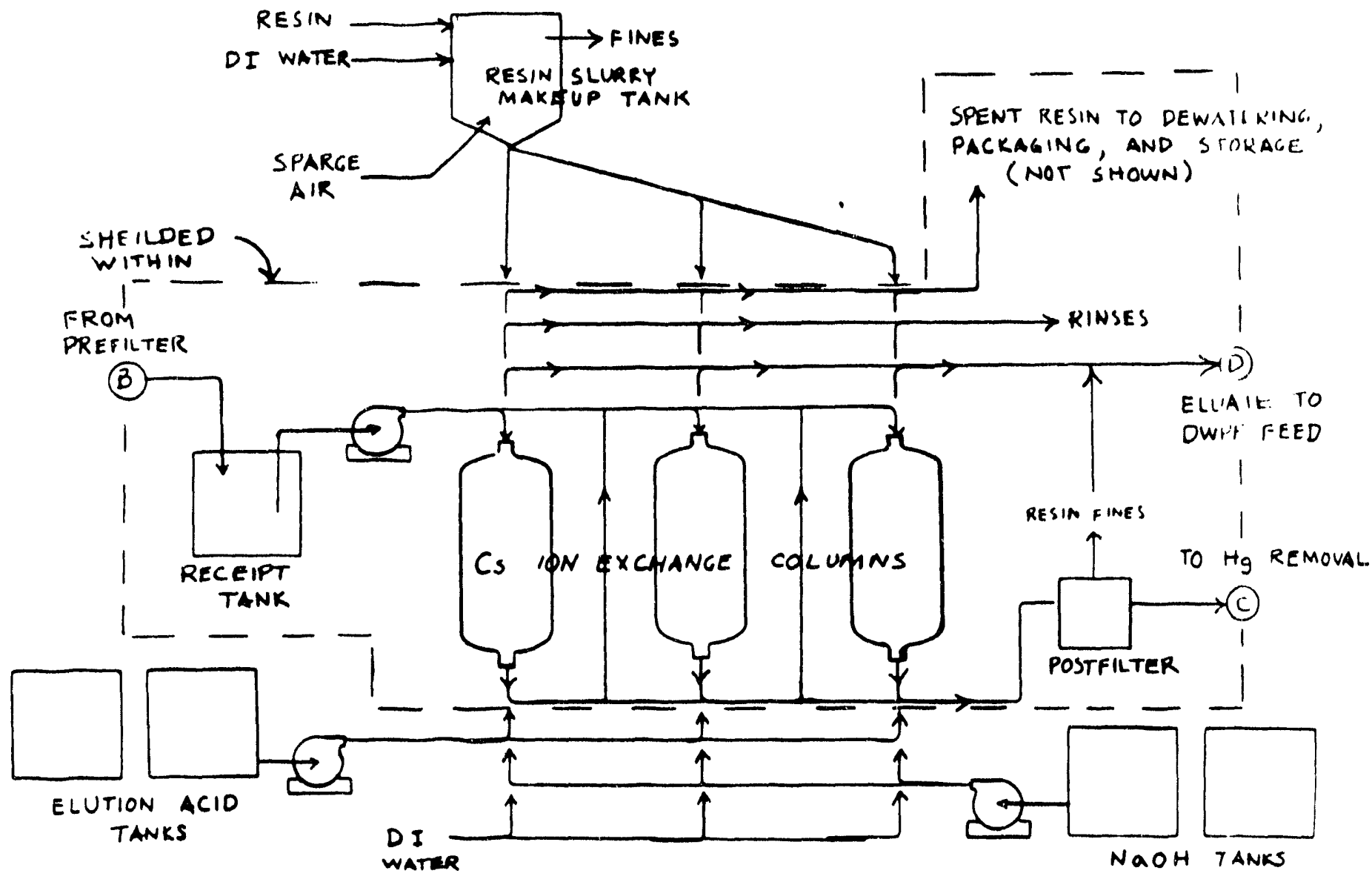




\section{Technology Assessment Report}

WSRC-RP-92-1093

\section{Mercuny Removal IX}

Two shielded break tanks will be used to ensure that the radioactivity level of the liquid feed to $\mathrm{Hg}$ removal is low, while providing uninterrupted feed. These tanks need only be large enough to provide ample analytical time (probably $<1000$ gallons). Off-spec. feed would be recycled.

A 2-column system will be used. Decontaminated effluent from Cs-removal IX will flow into the first column. The second column will be placed in series as a guard bed. When the first column is loaded (by time and feed analysis), feed will be diverted to the second column and there will be no guard bed until the first column has been replenished and put back on line. This is justified in iight of the high capacity $(\sim 1450$ bed volumes) of this resin; a small (200gallon) bed will last $\sim 10$ days. Also, mercury removal is somewhat gratuitous; periodic breakthroughs would not threaten Saltstone acceptance limits.

Mercury resin will be used once. A loaded column will be washed with 2 molar Nar!O3 to remove any Cs-137, and with water. A 5-10 bed volume NaNO3 solution makeup/feed tank and pump are required. Washed resin is slurried out with water, dewatered (drained), and packaged for disposal as nonhazardous LLW. Fresh resin is slurried in with water and conditioned with $2 \mathrm{M} \mathrm{NaOH}$. The same $\mathrm{NaOH}$ supply as used for $\mathrm{Cs}$ resin will be used. However, a dedicated (segregated) dry resin storage area and a dedicated resin slurry makeup tank are required to preclude inadvertent mis-loading. All washes and slurry water streams will go to "existing" tanks - provided for other purposes.

The mercury removal columns can be as large as practical for building space and handling. The $\mathrm{Hg}$-removal IX area will be essentially non-radioactive, with little or no shielding, and handson maintenance. Because the resin binds the $\mathrm{Hg}$ so well, there is no industrial hygiene $\mathrm{Hg}$ hazard from spills except possibly the column feed stream. This is also true in the loaded resin dewatering/packaging area. 


\section{MERCURYYONEXCHANGE DIAGRAM}

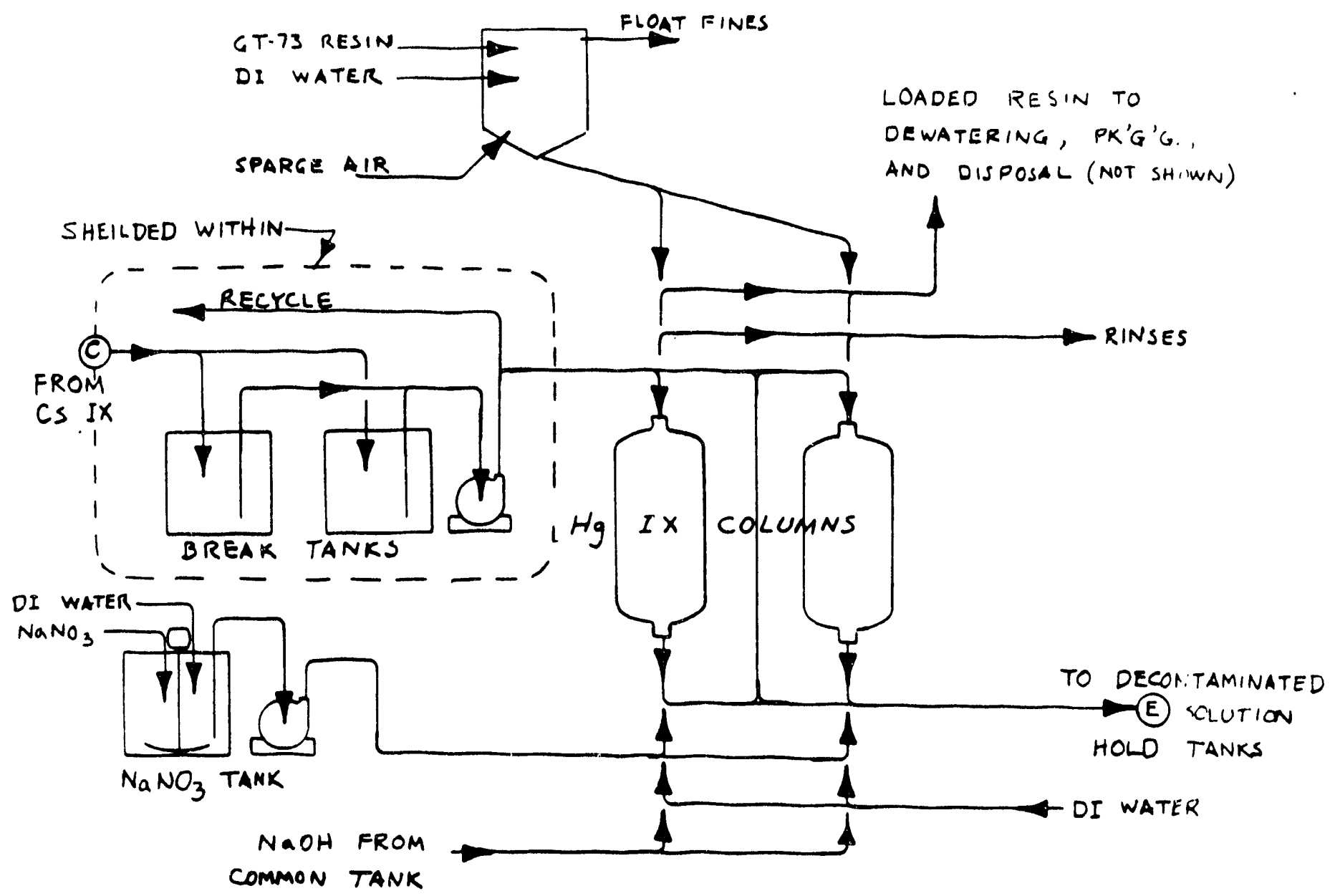

\section{Eluate Hold/DWPF Feed Tanks}

Two stainless steel (acid) Eluate Hold/DWPF Feed Tanks are required for receiving eluate, certain washes, and filtered solids; blending these streams; batch-filling the DWPF PRBT; and for temporary decoupling in case of IX or DWPF downtime. Tank:s must be agitated to suspend solids, cooled to 50 degrees $C$ for pumping to DWPF (nominal radioactivity heat load approximately 0.2 watts/gallon), and ventilated to remove radiogenic $\mathrm{H} 2$ gas.

Tanks must be sized to provide full DWPF batch complements (ca 5000 gal) on 86-hr cycle; receive10-bed-volume eluate batches; and blend (modulate) ST spikes so as not to exceed melter TiO2 criterion. In addition, spare capacity might be required to maintain overall DWPF attainment goal.

Pumps must be provided to deliver eluate to DWPF at $50.100 \mathrm{gpm}$ (rate not controlled). 
IX Technology Assessment Report

WSRC-RP-92-1093

The tanks must to heavily shielded and contained (nominal $80 \mathrm{Ci}$ Cs-137/gallon).

\section{ELUATE HOLD/OWPE FEER TANK DIAGRAM}

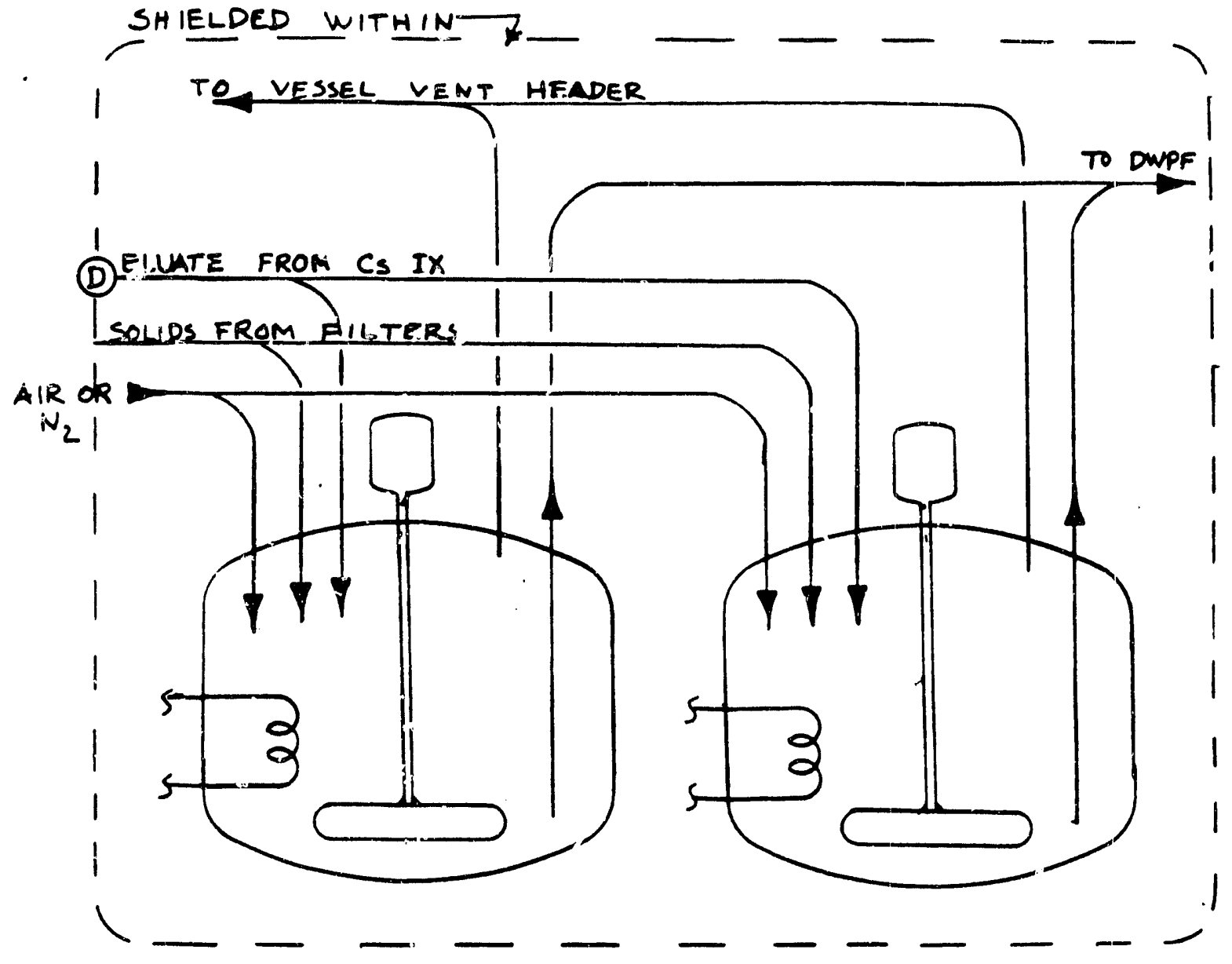




\section{Decontaminated Salt Solution Hoid Tanks}

Provide two lanks to receive, sample, and feed to Saltstone or Tank 50, the decontaminated effluent from IX. These tanks will also receive $2 \mathrm{M} \mathrm{NaOH}$ column conditioning rinses. When a tank is full it will be sampled and analyzed regarding Saltstone or Tank 50 feed limits.

Meanwhile, the other tank is filling. Tanks must be sized according to analytical turnaround time and maximum (sprint) IX processing rate.

Radioactivity level is low. Tank material is carbon steel. Cooling and agitation are not required.

\section{DECONTAMINATED SOLUTIONHOLD TANK DIAGRAM}

TO

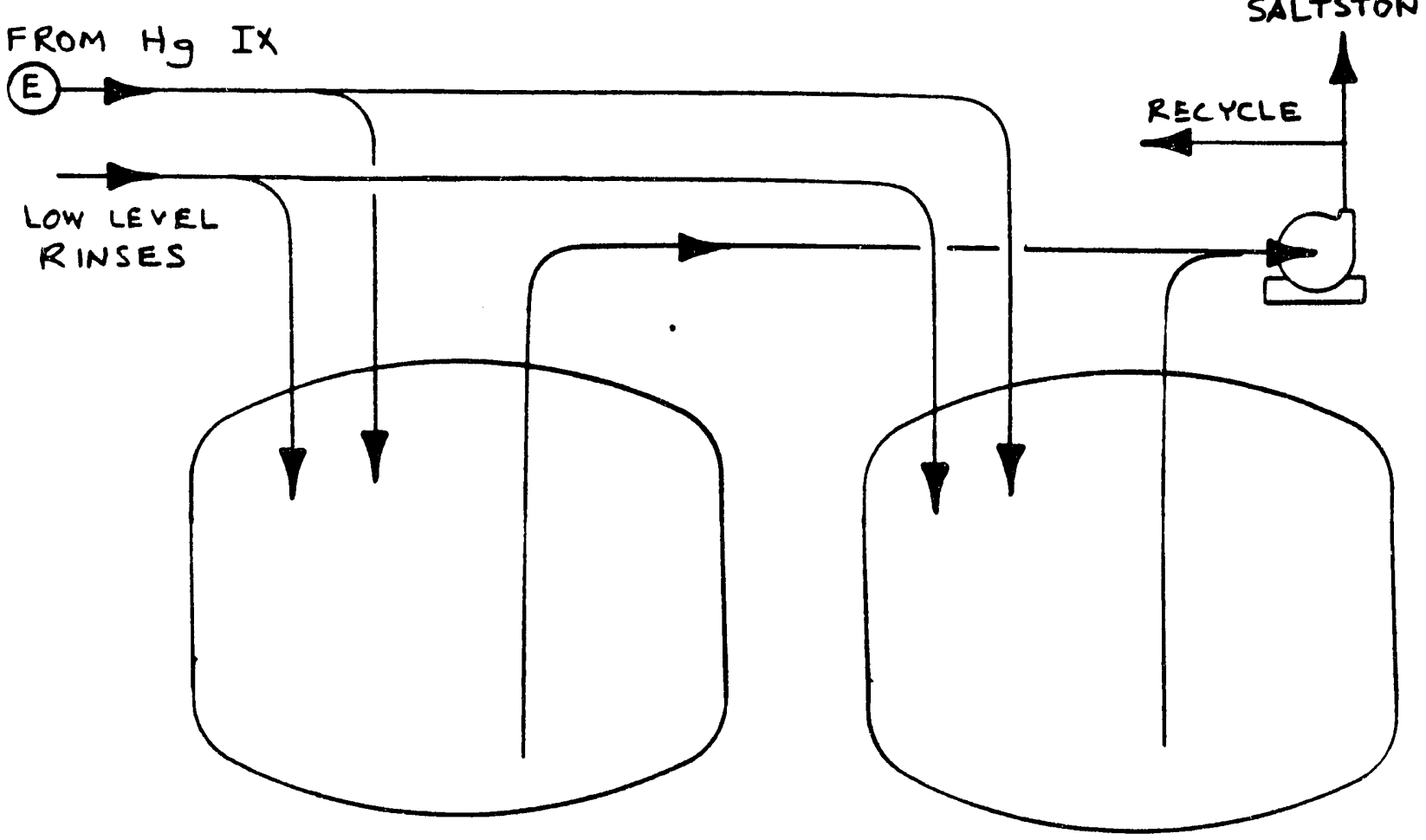

\section{KTPB Dissolution (Transition Process Only)}

Up to 1 million gallons of $10 \%$ potassium (with cesium) tetraphenylborate from Tank 49 will be dissolved in an aqueous-miscible organic solvent and fed to the IX prefilter. IX operations will proceed as before, with probably some rate decrease. The decontaminated effluent from IX will have a high organic content and probably will be unsuitable for Saltstone. Treatment by incineration or another oxidation process is envisioned. 
Although process details are sketchy, the following major equipment is expected to be required.

Dissolver Tank, c/st or s/st, $20-50,000$ gal, double-walled, cooled, flammable vapor control, possibly benzene abatement required, high activity waste duty.

Solvent storage and delivery system (cold)

Dissolved feed delivery pump

IX effluent oxidizer, or lag storage tank for CIF disposal. 5-10 gpm (total 1-2 million gallons), low activity, high organic content $(>50 \%)$. Tank may require flammable vapor control system.

\subsection{References}

1. "Radioactive Waste Management, Order 5820.2A," U. S. Department of Energy, Washington, D.C. (September 26, 1988).

2. Waste Acceptance Criteria for the Salistone Production and Disposal Facilities (Z-Area), July 31, 1992.

3. J. R. Fowler, "Removal of Radionuclides in 15-Year-Old SRP Soluble Waste by the Precipitation Process," Internal Report DPST-82-547 (revised), E. I. du Pont de Nemours \& Co., Inc., Savannah River Laboratory, Aiken, SC (May 21, 1982).

4. A. Goslen, "1988 Integrated Data Base," IOM to O. M. Morris, E. I. du Pont de Nemours \& Co., Inc., Savannah River Plant, Aiken, SC (April 8, 1988).

5. J. R. Fowler, "Composition of F Area Soluble High Level Waste," Internal Report DPST-82-390, E. I. du Pont de Nemours \& Co., Inc., Savannah River Laboratory, Aiken, SC (March 22, 1982).

6. J. R. Fowler, "Composition of H Area and SRP Soluble High Level Waste," Internal Report DPST-82-502, E. I. du Pont de Nemours \& Co., Inc., Savannah River Laboratory, Aiken, SC (April 28, 1982).

7. E. L. Wilhite, "Estimated Composition of Decontaminated Salt Solution Feed to Saltstone," Internal Report DPST-85-417, E. I. Du Pont de Nemours \& Co., Inc., Savannah River Laboratory, Aiken, SC (April 10, 1985).

8. "SRP/Z-Area Treatment Facility Construction Permit \#12,683, Aiken County," South Carolina Department of Health and Environmental Control, 2600 Bull St., Columbia, SC 29201 (October 31, 1986).

9. "Industrial Waste Permit IWP-217, Z-Area Saltstone Disposal Facility, Savannah River Plant, Aiken County," South Carolina Department of Health and Environmental Control, 2600 Bull St., Columbia, SC 29201 (October 31, 1986). [Note: this permit is reviewed and renewed every three years]

10. "Review of Shallow Soil Investigation for Permit IWP-217, Z-Area Saltstone Disposal Facility," South Carolina Department of Health and Environmental Control, 2600 Bull St., Columbia, SC 29201 (February 17, 1987). 
IX Technology Assessment Report

WSRC-RP-92-1093

11. "Permit to Operate - Z-Area Saltstone Processing Facility, Permit \#12,683, Aiken County," South Carolina Department of Health and Environmental Control, 2600 Bull St., Columbia, SC 29201 (October 31, 1988).

12. "Final Environmental Impact Statement on 10 CFR Part 61 "Licensing Requirements for Land Disposal of Radioactive Waste", NUREG-0945 Vol. 1, U.S. Nuclear Regulatory Commission, Washington, D.C.

13. J. R. Fowler, "Estimate of Soluble Mercury in Feed to Stage II of the DWPF," Internal Report DPST-81-648, E. I. du Pont de Nemours \& Co., Inc., Savannah River Laboratory, Aiken, SC (August 13, 1981).

14. D. D. Walker and J. R. Fowler, "Chromium Levels in Savannah River Plant Soluble Waste, Internal Report DPST-87-210, E. I. Du Pont de Nemours \& Co., Inc., Savannah River Laboratory, Aiken, SC (January 7, 1987).

15. DWPF Feed Acceptance Criteria, WSRC-IM-92-55, Draft 
IX Technology Assessment Report

WSRC-RP-92-1093

\section{ASSESS MEDIA.SELECT MOST PROCESSING}

A literature search and conversations with knowledgeable ion exchange researchers at other DOE sites and universities were used to quickly assemble an overview of the types of ion exchange media available for cesium, strontium/plutonium, and mercury removal from SRS high level soluble waste.

\subsection{Cesium Ion Exchange}

Many ion exchange sorbers have been used for cesium removal. These are noted below. The peculiar properties of SRS high level liquid waste $(\mathrm{pH}>13$; high aluminum content) preclude the use of most of them since they would require pH adjustment before use. The pros and cons of general categories of sorbers are discussed, where pertinent.

\subsubsection{Inorganic Ion Exchangers}

Inorganic ion exchangers may broadly be classified as: Natural inorganic exchangers (clay minerals and zeolites), synthetic zeolites, oxides and hydrous oxides, acidic salts of multivalent metals and cyanometalates.

\section{Natural Inorganic Materials}

The clay minerals and naturally occurring zeolites, though replaced to a large extent by synthetic exchangers, continue to be used and have been applied extensively to the treatment of radioactive waste solutions. Limitations to their use include $i_{\text {. }}$ ) relatively low ion exchange capacities, ii.) low abrasion resistance of the zeolites, iii.) clay minerals tend to peptize and form colloids in some, particularly alkaline, solutions, and iv.) these materials are partially decomposed by acids and alkali.

British Nuclear Fuels, Ltd. (BNFL) employs a natural zeolite ${ }^{1}$ in its decontamination process at Sellafield, England. Extensive research with Sellafield wastes determined clinoptilolite as the candidate for the British process. The material from a California mine (and the mine source) was purchased by BNFL. Sellafield first pH-adjusts its waste, which is very dilute compared to SRS waste, to $\mathrm{pH} 8$ using carbon dioxide. This prevents the dissolution of the zeolite matrix, which becomes unstable above pH 10.

Adjusting SRS waste to pH's below 10, to protect the zeolite, would generate large amounts of precipitate that would have to be filtered prior to ion exchange. A scouting experiment with simulated SRS supernate (See attachment 1) showed that pH adjustment to 9 with nitric acid precipitated all the aluminum and other metals that form insoluble hydroxides at that $\mathrm{pH}$. The precipitation of mercury would also occur on pH adjustment. Filtration of the gelatinous precipitate would be a major process step. Thus, natural zeolites were deleted as a choice for treatment of SRS waste.

\section{Synthetic Zeolites}

These materials are commercially available and include IE-96 and IE-95. They act as molecular sieves by excluding ions larger than the opening in the crystalline matrix. Limitations to the use of synthetic zeolites are similar to those listed for naturally occurring zeolites. But the synthetic zeolites possess improved stability and a slightly higher cation exchange capacity. The Bray IE-96 coated with titanate 2 is being used successfully to treat West Valley wash waters for Cs and Pu removal from pH 12 solution. It is the consensus of SRS, 
West Valley, PNL (Pacific Northwest Laboratories), and Hanford personnel active in ion exchange work that SRS waste is too caustic to allow use of even the synthetic zeolites.

Work by Bray at $\mathrm{PNL}^{3}$ indicates that the throughput for synthetic zeolites using Hanford's NCAW or SRS supernate would be low (about 70 column volumes at $10^{\circ} \mathrm{C}$ ) relative 10 other exchangers available.

\section{Oxides and Hydrous Oxides}

Only a few of these materials are available in commercial quantities. Many show high exchange capacity, low solubility and good radiation and thermal stability. Although hydrous oxides are at their most active when freshly precipitated, they are at their least useful as regards ion exchange column applications. Their relative high ion exchange capacities are offset by their ease of dissolution in acids or bases and the poor filtration characteristics of the precipitates in general render them unsuitable for use as column sorbents. The quantitative effect of heat treatment of different oxides and hydrous oxides on their ion exchange properties varies considerably. Sandia National Lab/Texas A\&M personnel have recently developed a heated version of titanate that is supposed to have superior Kd's and stability in highly caustic waste. ${ }^{4}$ To date, the material has not been made in large batches, though researchers predict that scaleup should present no problem. Generally, ion exchange capacities show a steady decrease with heating but heat treatment can improve both the selectivity and the chemical stability of these sorbers. Such sorbers include hydrous titanium oxide and manganese dioxide. Work is proceeding at Texas A\&M University on $\mathrm{Zr}$ and $\mathrm{Ti}$ materials, but not on an industrial scale. Further, $\mathrm{Cs}$ removal has not been achieved above $\mathrm{pH} 6$ for these materials. The use of an oxide or hydrous oxide absorber as a column material is obviously governed to a large extent by its resistance towards breakdown or dissolution when treated with various reagents. In general, the insoluble acidic oxides and hydrous oxides are stable in acid solutions but dissolve readily at $\mathrm{pH}>7$. In contrast the more basic hydrous oxides such as $\mathrm{TiO}_{2}$ and $\mathrm{ThO}_{2}$ dissolve readily in mineral acids above about $0.1 \mathrm{M}$ but are stable in less acidic solutions. ${ }^{4}$

Except for the Sandia silico-titanate material, these sorbers were discounted because of their lack of stability in high caustic and the fact that they are not available in large quantifies commercially. One issue that must be resolved with the Los Alamos product is the $0.1 \%$ acetone that is associated with it. In a large waste tank the acetone may present a problem similar to that of benzene. Researchers, having been apprized of this concern, are exploring a way to eliminate the acetone without destroying the selectivity of the sorber.

\section{Acids of Multivalent Salts}

A wide range of compounds of this type have been described as ion exchangers. These salts, acting mostly as cation exchangers, are gel-like or micro-crystalline materials with the composition and properties depending on the method of preparation. In general, they are not available in commercial quantities and many are likely to be expensive to produce because of the limited availability and high cost of the materials required in their preparation. These include antimonic acids, zirconium phosphates and titanium phosphates.

\section{Cyanometallates}

The ion exchange properties of a large number of insoluble cyanoferrates of various metals have been studied. These absorbers act as cation exchangers with an especially high affinity for Cs. The exchange capacity depends strongly on the method of preparation and this has presented difficulty in the past relative to purchasing a consistent product. They are available in research 
quantities but because of the relatively simple method of preparation, it has been reported that larger scale manufacture (in Finland) would be feasible and economic. Cyanoferrate exchangers are stable in mineral acids; in contact with strong nitric acid, a slight oxidation of $\mathrm{Fe}$ (II) to $\mathrm{Fe}$ (III) can occur. In alkaline solutions, a tendency to peptize has been observed but this can be reduced by addition of neutral salts. R.M. Wallace studied this exchanger and reported that it was a.) difficult to purchase in consistent quality and b.) not stable in SRS waste. 5 A paper by Prout, Russell, and Groh, of SRS, 6 describes the preparation and performance of granular potassium hexacyanocobalt(II)ferrate(II). The material was capable of decontaminating $0.5 \mathrm{M}$ $\mathrm{NaOH} ; 4 \mathrm{M} \mathrm{NaNO}_{3}$ containing $0.001 \mathrm{M} \mathrm{Cs}^{+}$simulant operating in a column mode. Its production has not been commercialized. In light of the public perception of cyanides in radioactive waste at Hanford, it would probably require public buy-in for the use of these materials with our waste.

\section{Organic/lnoraanic Resins}

Other options for the use of inorganic media are to chemically bond them to an organic resin for good column operation or to put amine (for example) functional groups on inorganic exchangers to modify their structure for greater selectivity. All of these options are at laboratory development scale only, being studied mainly in England at the Universities of Salford 7 and Reading 8 and in Italy. ${ }^{9}$

\section{Duracil Glass}

A cesium-specific glass sorter was developed by researchers associated with Catholic University and Duratec, Inc. It could have had great use with radioactive waste that is destined to be vitrified. It was tested by R.M.Wallace at SRS under the terms of a secrecy agreement. He found that the glass dissolved in SRS waste but could be used to recover Cs from TPB precipitate dissolved in butyryl lactone. 10 No further work was done with this sorbant.

\subsubsection{Organic Ion Exchangors}

There are a number of organic ion exchangers on the market that will remove $C s$ ion from solution. The difficulty in using an organic exchanger is the low relative selectivity for cesium in the presence of sodium. The ETF, for example uses HPK-25, a highly porous, highly crosslinked sulfonic acid resin, to remove $\mathrm{Cs}^{+}$from its final effluent stream. The $\mathrm{Na}^{+}$concentration in that stream. however, is only about $250 \mathrm{ppm}$. In high level supernate it may be as high as $6 \mathrm{M}(138,000 \mathrm{ppm})$. The sulfonic acid resin will not be selective enough at that concentration. Also, because of the lack of selectivity, the amount of resin that would have to be used would be prohibitive. Phenolic resins have the advantage in that they are stable and $I X$-active at high $\mathrm{pH}$ $(>14)$ and are more selective than ordinary resins. The best resin on the market is a phenolic resin, Duolitem CS-100, marketed by rohm \& Haas. Hanford has based its design on that resin, though Blaine Banton indicated in private conversations that Hanford will actually use an SRSdeveloped resin if its supply can be assured. The SRS resorcinol/formaldehyde resin is a phenolic resin which has been demonstrated by SRS, PNL, and Oak Ridge $11-14$ researchers to have at least $10 x$ the capacity of the Cs-100. This means a ten-fold greater throughput or columns one-tenth the amount of resin required for CS-100. The SRS resin generates slightly more C per Cs as the reference process at SRS (NaTPB precipitation/hydrolysis) generates to the DWPF. It can be efficiently eluted with acid. It is the most attractive candidate for SRS Csdecontamination by ion exchange. CS-100, commercially available, already tested with SRS, Oak Ridge, and WH wastes, is a back-up candidate. 
Concern has been expressed that ion exchange will not be able to accommodate large swings in concentrations that may be experienced in the feed. Two parameters that are important, according to work by Bibler, Campbell, and Bray are the $\mathrm{Na}^{+} / \mathrm{Cs}^{+}$ratio and the $\mathrm{K}+/ \mathrm{Cs}^{+}$ratio. Sodium to cesium ratio variations of $\pm 100 \mathrm{X}$ might be experienced and would have to be studied to show the amount of Cs-137 proceeding to the glass melter. Campbell has shown that the performance of the SRS resin at a $\mathrm{K}^{+} / \mathrm{Cs}^{+}$ratio of $1 \mathrm{E}+5$ is nearly constant over the expected range of potassium ion in SRS waste, i.e. $0.009 \mathrm{M}-0.08 \mathrm{M} .^{13}$ SRS waste has a range of $\mathrm{K}+/ \mathrm{Cs}^{+}$ratios of $10^{2-10^{4}}$. Further work on the effect of counter ion concentrations is planned by Bray at PNL.

\subsection{Mercury Ion Exchange}

Duolite ${ }^{\text {TM }}$ GT.73 is the resin of choice for mercury removal from SRS supernate. ${ }^{15}$ The resin has been demonstrated effective with simulated and actual supernate solutions. It is in use for mercury removal at the F/H Effluent Treatment Facility and in the TNX Effluent Treatment Facility. It has been demonstrated with actual high level soluble waste that spent resin can be washed with sodium nitrate to remove residual radioactivity to yield a waste containing $>1 \mathrm{nCi} / \mathrm{g}$ Cs-137. The spent resin has passed the EP-Toxicity ${ }^{16}$ and TCLP (Toxic Component Leaching Procedure) leach tests for mercury, lead, silver, and $\mathrm{Cr}$ (III) ions.17 Thus, washed, spent resin should not be a hazardous waste and may be sent to the burial ground for disposal. Its sulfur functional groups preclude it from going to the melter where it would generate corrosive $\mathrm{SO}_{2}$. Recent conversations with the manufacturer, Rohm \& Haas, indicate that the company is still manufacturing small quantities of this resin and would increase its production to meet SRS needs. A substitute resin, Puroliten 920 has also been identified.

\subsection{Sr/Pu Ion Exchange}

D.D. Walker and R.M. Wallace of SRTC have tested various organic ion exchangers for $\mathrm{Sr}$ removal. Their conclusion 18 was that Lewatitm TP-207 gave the best performance with SRS decontaminated supernate. TP-207 is an imindiacetate resin. It was not tested with this waste for Pu removal but similar resins remove Pu from SRTC laboratory wastes.

It is possible to use sodium titanate, either on an organic resin or in its pure form as a sorbing medium for decon of $\mathrm{Sr}$ and $\mathrm{Pu}$.

\subsection{Media selected for Further Consideration for This Study}

The preferred ion exchange process steps determined by this study will be: a.) Cesium ion exchange using the SRS resin because of its stability in highly caustic waste and because of its demonstrated selectivity for Cs ion in a high sodium matrix. b.) Duolite GT-73 is the resin of choice for other waste streams based on its success in use at SRS, its tested efficiency of $\mathrm{Hg}$ removal, and its ability to generate a non-hazardous secondary waste stream. A near-equal resin, commercially available, is Purolite 920 which might be substituted for GT-73 if desired. c.) Sr/Pu ion exchange on Lewatit@ TP-207 has been deleted in favor of sorption on sodium titanate in batch mode, followed by filtration. 
IX Technology Assessment Report

WSRC-RP-92-1093

Table 1. Costs of lon Exchange Media

Ion Exchanger \$/cubic foot

IE- 96

300

CS. 100

250

SRS 1000

GT -73

850

TP.207

300

Sodium titanate

$46 / 1 b$

Table 2. Ion Exchange Media Considered and Reasons for Rejection(R)/Acceptance(A)

Medium

Natural Zeolites

Clay Minerals

IE-95, IE-96

Bray titanate on IE-96

Pillared Clays

Zr Oxides

Ti Oxides

Antimonic acids

Zirconium phosphates

Titanium phosphates

Metallocyanides

Amine additives to size clay

Glass sorber

CS -100

SRS resin

GT -73

TP. 207

Sodium titanate

Silico-titanates
Conclusion

(R)Unstable at pH 14 - requires $\mathrm{pH}$ adjustment

(R) Unstable at $\mathrm{pH} 14$

(A)Considered but requires $\mathrm{pH}$ adjustment to overcome high pH instability

(R)Requires pH adjustment- May use more zeolite

(R) Sensitivity to $\mathrm{pH} 14$ waste-lab scale only

(R)Sensitivity to pH 14 waste-lab scale only

(R) Sensitivity to pH 14 waste-lab scale only

(R) Sensitivity to $\mathrm{pH} 14$ waste-lab scale only

(R)Sensitivity to $\mathrm{pH} 14$ waste-lab scale only

(R) Sensitivity to $\mathrm{pH} 14$ waste-lab scale only

(R)Sensitivity to $\mathrm{pH} 14$ waste-cyanides in waste tank

(R) Sensitivity to $\mathrm{pH} 14$ waste-lab scale only

(R)Dissolves in SRS waste

(A)Commercially available but $1 / 10$ capacity of SRS resin

(A)Best capacity and selectivity of all sorbers listed for Cs ion

(A)Tested and proven best for mercury removal

(A)Tested and proven best for $\mathrm{Sr}$ - not selective for Sr-should also remove $\mathrm{Pu}$

(A)Already in use for $\mathrm{Sr}$ and $\mathrm{Pu}$ removal from SRS waste

(R)Look good but still small-scale production not tested at SRS pH's 
IX Technology Assessment Report

WSRC-RP-92-1093

Table 3. Ion Exchange Media Leading Candidates - Rationales

Medium

IE-96 Zeolite

Duolite ${ }^{\mathrm{TM}}$ CS.100

SRS Resorcinol/formaldehyde

GT-73/Purolite 920

TP. 207

Sodium titanate

\section{Rationale}

This has been successfully used at West Valley, Three Mile Island, and for some Hanford wastes.

Phenolic sorber commercially available on which SRS and Hanford have considerable data. Stable at high pH. Reliable availability questionable.

Phenolic sorber on which SRS, Oak Ridge, and PNL have considerable data. 10x better than CS-100. Availability questioned, though two potential vendors identified. Stable at high pH.

Demonstrated at SRS for Hg-removal. Passes TCLP

Screened at SRS as best organic medium.

SRS and West Valley experience show it is good for Sr and Pu decon. 
IX Technology Assessment Report

WSRC-RP-92-1093

Table 4. Comparison of Ion Exchange at Different Sites

Site Medium Waste eperating Cenditions

\begin{tabular}{|c|c|c|c|}
\hline \multirow[t]{2}{*}{ West Valley } & IE-96 & $\begin{array}{l}\text { Supernate: } \mathrm{pH} \text { 10-11, } \\
7 \mathrm{M} \mathrm{Na}{ }^{+}, \mathrm{Cs}^{+} \sim 1.4 \mathrm{E}-3 \mathrm{M}\end{array}$ & $\begin{array}{l}\text { Remove } \mathrm{Cs}^{+} \text {on IE-96: } \\
\text { IE-96 to glass }\end{array}$ \\
\hline & Titanate on IE.96 & $\begin{array}{l}\text { Sludge wash: } \mathrm{pH} 12 \text {, } \\
0.034 \mu \mathrm{Ci} / \mathrm{mL} \mathrm{Sr} \text {, } \\
0.081 \mu \mathrm{Ci} / \mathrm{mL} \mathrm{Pu}, \\
498 \mu \mathrm{Ci} / \mathrm{mL} \text { Cs }\end{array}$ & $\begin{array}{l}\text { Wash } 3 \times \text { to get right } \\
\mathrm{Na} / \mathrm{Cs} \text { ratio, } \mathrm{pH} \text { adjust } \\
\text { to } 12 \text {, spent zeolite to } \\
\text { glass }\end{array}$ \\
\hline
\end{tabular}

Hanford CS-100, SRS CC Waste: $0.5 \mathrm{M} \mathrm{OH}^{-}, \quad$ Use directly on resin, resin $\quad 10 \mathrm{M} \mathrm{Na} \mathrm{Na}^{+}, 0.5 \mathrm{M} \mathrm{Al3}{ }^{+}, \quad$ elute with acid, acid to 4.6M NO${ }^{-}, 46 \mathrm{~g} / \mathrm{L}$ TOC glass.

NCAW Waste: $2.0 \mathrm{M} \mathrm{OH}^{-}$, Use directly on resin, $6 \mathrm{M} \mathrm{Na}^{+}, 0.5 \mathrm{M} \mathrm{Al3}{ }^{+}$, olute with acid, acid to $1.9 \mathrm{M} \mathrm{NO}_{3}^{-}$glass

TMI IE-95/IE-96

Reactor coolant system: $\quad$ Sr and Cs removed on $1350 \mathrm{ppm} \mathrm{Na}, 3870 \mathrm{ppm}$ zeolites, polished on B, $1.5 \mathrm{ppm} \mathrm{Cs,}<0.05 \mathrm{ppm}$ organic resins - to storage Sr, $0.17 \mu \mathrm{Cl}$ tritium

Containment building water: Sr and Cs removed on 1200 ppm Na, 2000 ppm zeolites, polished on $\mathrm{B}, 0.8 \mathrm{ppm} \mathrm{Cs,} 0.1 \mathrm{ppm}$ organic resins - to storage Sr, $1.0 \mu \mathrm{Cl}$ tritlum

BNFL Clinoptilolite Pond water: $100 \mathrm{mg} / \mathrm{L} \mathrm{Na} \mathrm{pH}$ adjust with $\mathrm{CO} 2$ from Sellafield $1.5 \mathrm{mg} / \mathrm{L} \mathrm{Ca}, 0.7 \mathrm{mg} / \mathrm{L} \mathrm{Mg}, 11-8$, load on zeolite, $2.23 \mu \mathrm{g} / \mathrm{L} \mathrm{Cs}, 0.01 \mu \mathrm{g} / \mathrm{L} \mathrm{Sr}$, store spent zeolite for $10 \mathrm{mg} / \mathrm{L}$ silicate, $\mathrm{pH} 11.5$ encapsulation in cement

SRS

Soluble waste: $2.9 \mathrm{M} \mathrm{OH}^{-}$, NaTPB precipitation for 5.5 $\mathrm{M} \mathrm{Na}^{+}, 0.38 \mathrm{M} \mathrm{Al} 3^{+}, \quad \mathrm{Cs}$ and $\mathrm{ST}$ for $\mathrm{Sr} / \mathrm{Pu}$, 4.5 $\mathrm{M} \mathrm{NO}_{3}^{-}$(simulant) ppt hydrolysis, to glass 


\subsection{Solectlon of Most Promising Flowsheets}

\subsubsection{Introduction and Summary}

Several alternative configurations using two media (SRS resin and zeolite) were selected for further evaluation. The evaluation included development of block flow diagrams with sufficient detail to generate simplified flowsheets. The purpose of the simplified flowsheets is to provide a comparison of possible process alternatives based on equivalent operating conditions, bases, and assumptions. The simplified flowsheets are designed to elucidate principal differences among the alternatives and to judge integration with and impact on the DWPF.

Three basic cases were chosen for conceptual flowsheeting:

- Organic resin with spent resin fed to the DWPF, both once-through and with regeneration by elution

- Zeolite with spent exchanger fed to the DWPF; evaluated at two temperatures because of significant improvement of $\mathrm{Kd}$ at reduced temperature

- Organic resin with regeneration by elution and low level waste disposal of the spent resin

In addition, one case (once-through) is evaluated with a TP-207 column. The summary of cases is

Case 1A Organic resin (to DWPF) - once-through

Case 1B Organic resin (to DWPF) - once-through with TP.207 (maximum resin carbon

Case 2A

Case 28

Case $3 A$ to melter; maximum redox balance/noble metals deposition concerns)

Case 38 Organic resin (to DWPF) - elution with formic acid Organic resin (to DWPF) - elution with nitric acid Zeolite (10 DWPF) @ $40^{\circ} \mathrm{C}$

Zeolite (to DWPF) @ $10^{\circ} \mathrm{C}$

Case 4 Organic resin (to LLW) - elution with formic acid

One example of each basic configurations is chosen for further discussion here. Details of all the cases are contained in Appendix $B$. 
IX Technology Assessment Report

WSRC-RP-92-1093

A comparison of the three cases is tabulated below

\begin{tabular}{|c|c|c|c|c|}
\hline & \multirow{2}{*}{\multicolumn{2}{|c|}{$\begin{array}{l}\text { SRS Rosin } \\
\text { once-through }\end{array}$}} & \multirow{3}{*}{$\begin{array}{l}\text { Zeolite } \\
T=10^{\circ} \mathrm{C}\end{array}$} & \multirow{3}{*}{$\begin{array}{l}\text { SRS Resin } \\
\text { w/ elution \& } \\
\text { LLW disposal }\end{array}$} \\
\hline & & & & \\
\hline & & w/ TP.207 & & \\
\hline & Befarence & CASE 18 & CASE 3B & CASE 4 \\
\hline Decon salt soln & 14840 & 12481 & 17297 & 12406 \\
\hline Water to SPC & 922 & 1531 & 1034 & 778 \\
\hline HCOOH D SPC & .................. & $. .8 . .$. & ...8... & 24,6 \\
\hline HNOS & 0 & 0 & 0 & 0 \\
\hline Organic resin & 0 & 23.4 & 0 & 0 \\
\hline Zeolite & 0 & 0 & 98 & 0 \\
\hline Frit & 152 & 160 & 120 & 160 \\
\hline Glass & 228 & 228 & 267 & 228 \\
\hline
\end{tabular}

\section{5 .2}

Case 18

Organic resin - once through with TP.207 column

This alternative shows the maximum carbon load that would be expected on the melter. The carbon load results from once-through on both the Cs resin (SRS) and the Sr/Pu resin (TP. 207).

A simplified block diagram for this alternative is

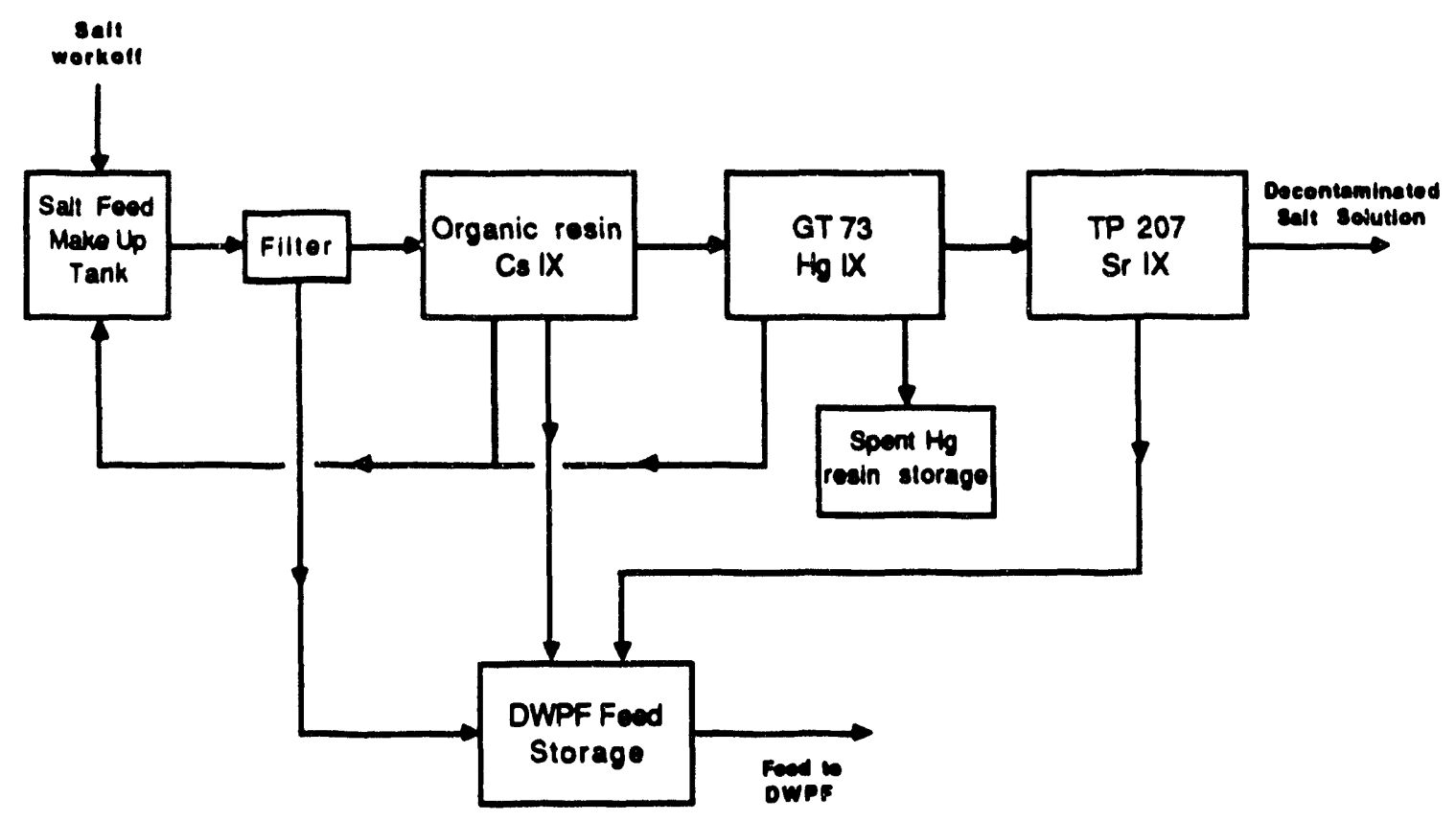


IX Technology Assessment Report

WSRC-RP-92-1093

A summary of the primary streams is (flows in $\mathrm{lbs} / \mathrm{hr}$ )

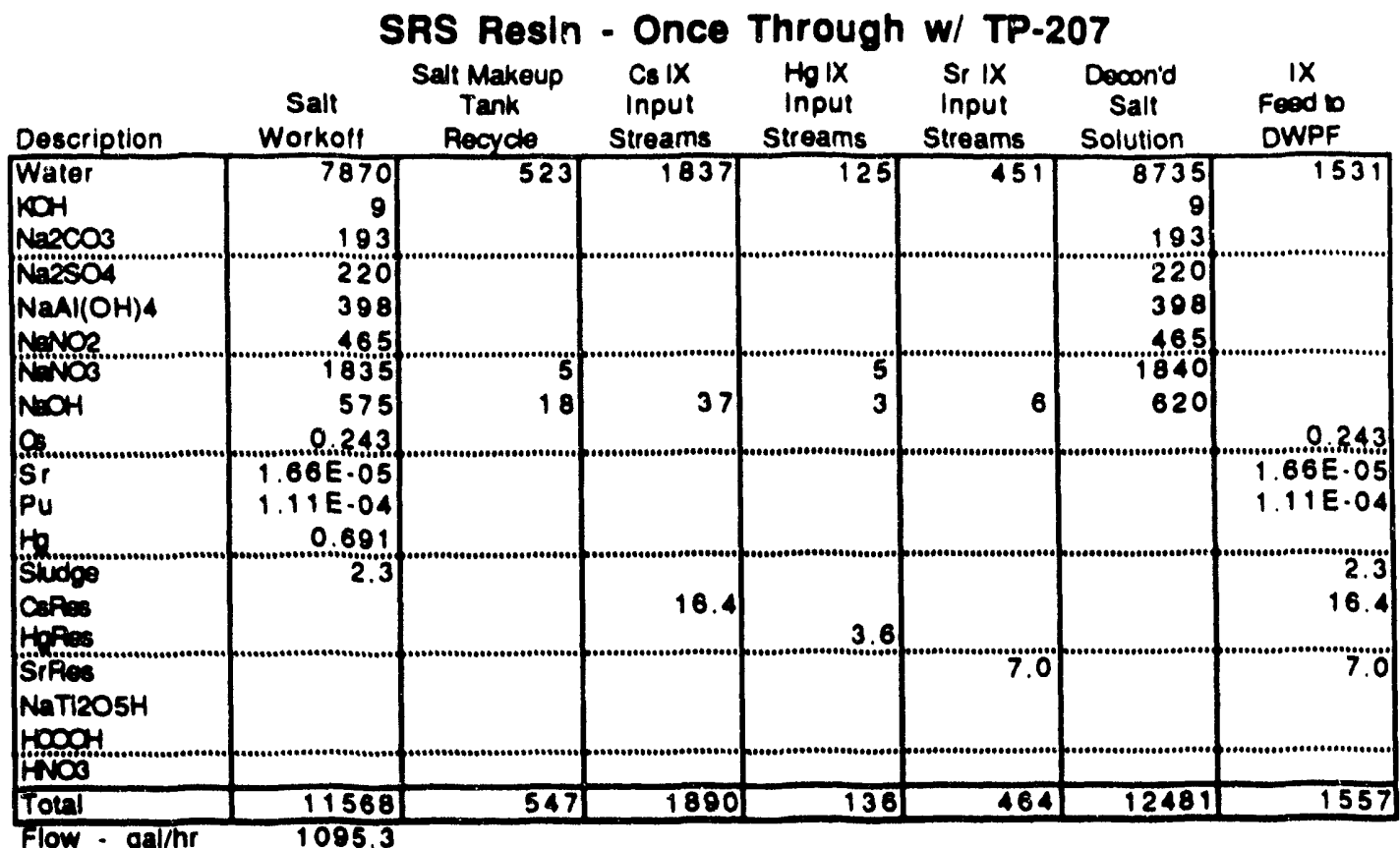

\begin{tabular}{|c|c|c|c|c|c|}
\hline & \multirow{2}{*}{$\begin{array}{c}\text { DWPF } \\
\text { Roference }\end{array}$} & \multirow[b]{2}{*}{ CASE 1B } & \multicolumn{2}{|c|}{ Chanos } & \multirow[b]{3}{*}{$\begin{array}{l}\text { gal/min } \\
\text { gal/min }\end{array}$} \\
\hline & & & Percent & vol or $m$ & \\
\hline $\begin{array}{l}\text { Decon'd salt soln } \\
\text { Water to SPC } \\
\text { Recycle water }\end{array}$ & $\begin{array}{r}14840 \\
922 \\
3820\end{array}$ & $\begin{aligned} 12481 \\
1531 \\
4429\end{aligned}$ & $\begin{array}{r}-15.9 \% \\
66.1 \% \\
15.9 \%\end{array}$ & $\begin{array}{r}-3.7 \\
1.2\end{array}$ & \\
\hline $\begin{array}{l}\text { HCOOH o SPC } \\
\text { HNOS } \\
\text { Organic resin }\end{array}$ & 21.4 & 23.4 & & $\begin{array}{r}-21.4 \\
23.4\end{array}$ & $\begin{array}{l}\text { Ibs/hr } \\
\text { ibs/hr } \\
\text { lbs/hr }\end{array}$ \\
\hline $\begin{array}{l}\text { Zeolite" } \\
\text { Frit } \\
\text { Class }\end{array}$ & $\begin{array}{l}152 \\
228\end{array}$ & $\begin{array}{l}160 \\
228\end{array}$ & $5.3 \%$ & 8 & $\begin{array}{l}\text { lbs/hr } \\
\text { lbs/hr } \\
\text { lbs/hr }\end{array}$ \\
\hline
\end{tabular}

"does not include zeolite in waste tanks

"estimated increase in frit caused by glass formers (eg. H3BO3, alkali)

in precipitate that is included in Fitt 165

While this alternative results in a $15 \%$ decrease in decontaminated salt solution to $Z$ Area, it significantly increases the amount of water entering the SPC (Salt Process Cell) by $16 \%$ (DWPF recycle increases by $6 \%$ ). It is interesting to note, however, that the non-volatile carbon load on the melter caused by the organic resins is somewhat offset by the decreased formic acid/formates to the melter.

If the TP-207 column is not required and the resin is eluted, then the organic resin load on the melter would be as low as $3 \mathrm{lbs} / \mathrm{hr}$ and the water to the SPC would be lower than reference. If the elution acid is formic, the quantity of formic acid/formate fed is similar to the reference case. 
IX Tachnology Assessment Report

WSRC-RP-92-1093

\subsection{3}

Case 38

Zeollte resin@10 $\mathrm{C}$

This alternative is chosen for evaluation because zeolitcs are used extensively for ion exchange in general and for $\mathrm{Cs}$ removal in particular. An operating temperature of $10^{\circ} \mathrm{C}$ (which requires refrigeration equipment) significantly increases the Kd and decreases the zeolite flow to the melter.

As previously discussed, there is a problem with application to SRS salt solutions. The $\mathrm{pH}$ of our salt solutions is 12.14 and zeolites typically require pHs in the range of 10-12. The conceptual zeolite process includes nitric acid addition to reduce the $\mathrm{pH}$, filtration to remove the resultir.g solids (prinripally aluminates), and dissolution of those solids for recombination with the decontaminated salt solution.

A simplified block diag: $3 m$ for this alternative is

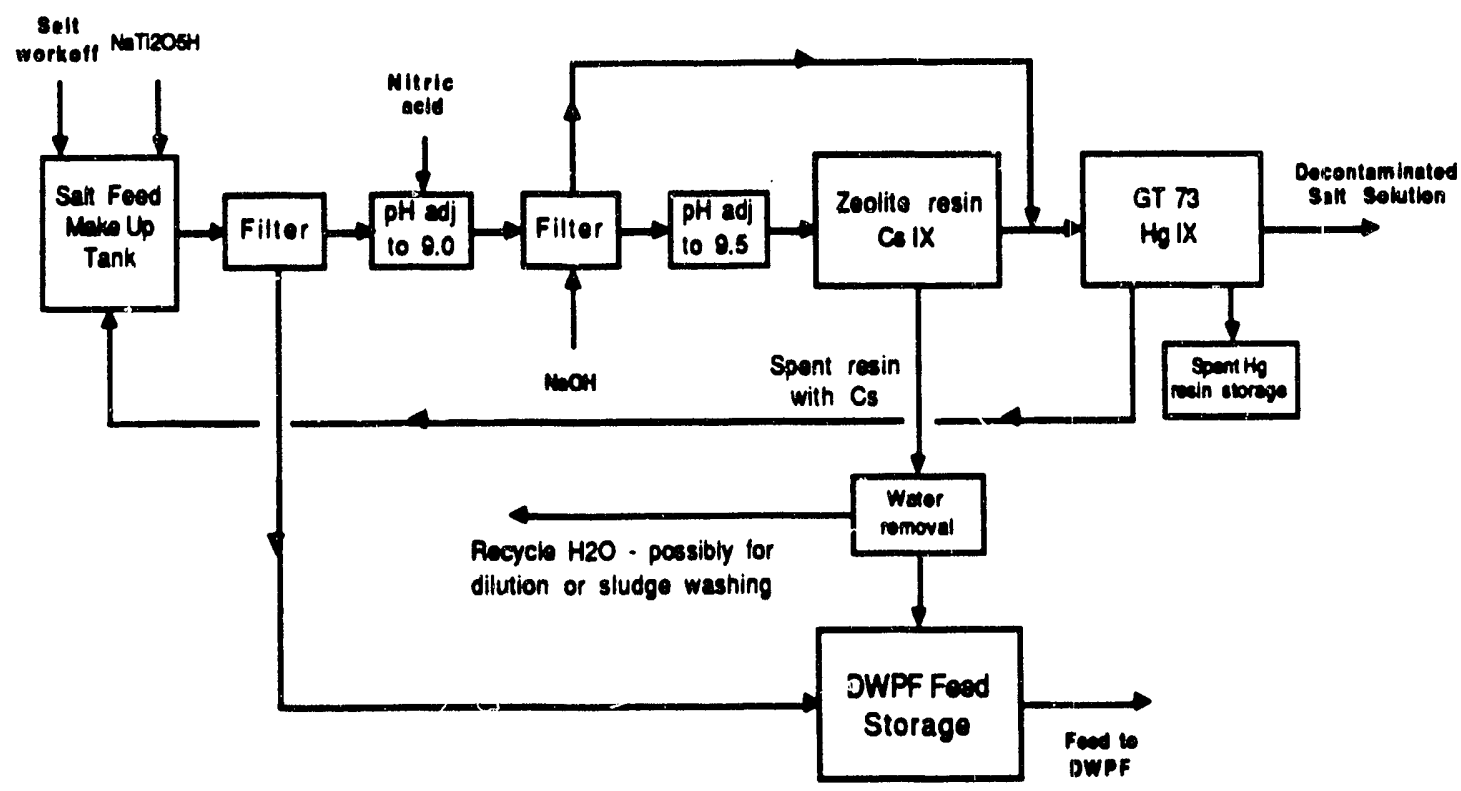

A summary of the primary streams is (flows in $\mathrm{lbs} / \mathrm{hr}$ ) 


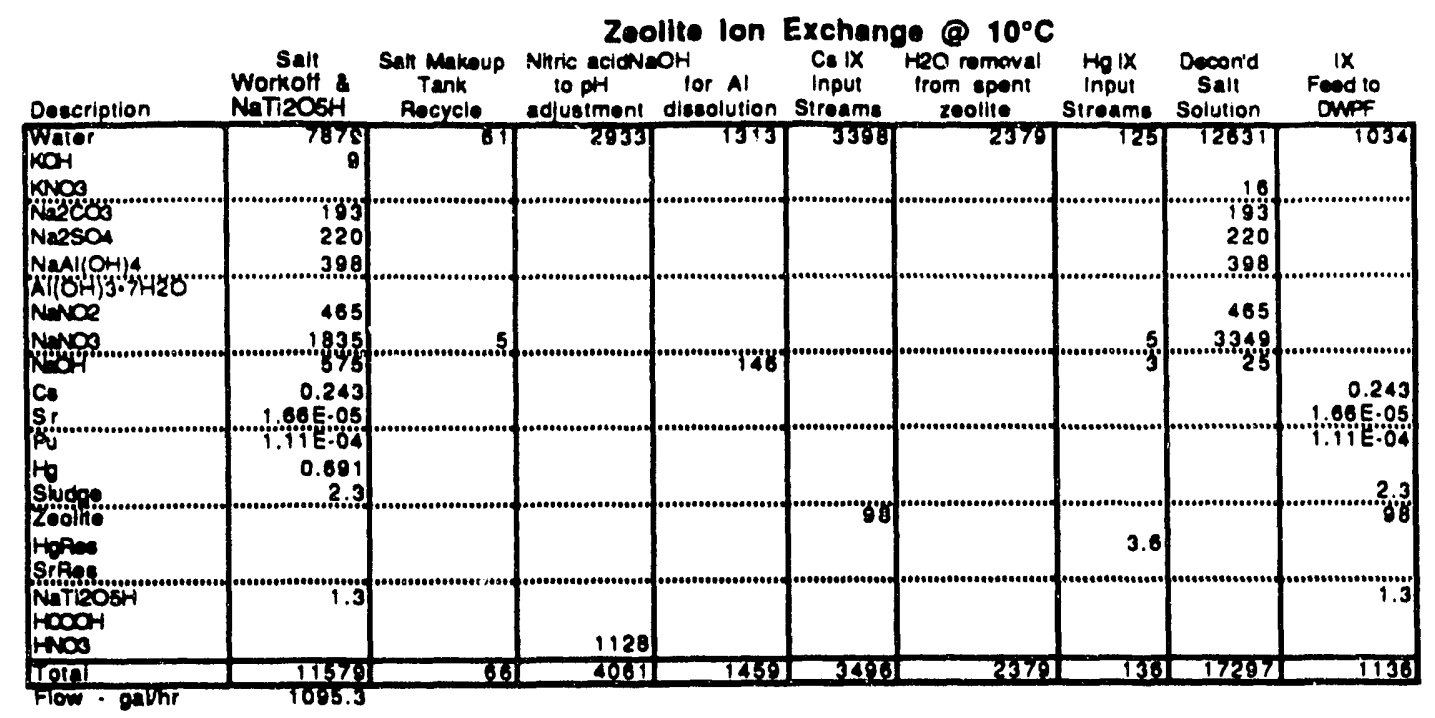

\begin{tabular}{|c|c|c|c|c|c|}
\hline & DWPF & & & ange & \\
\hline & Reter & CASE 38 & Percent & vol or $\mathrm{wt}$ & \\
\hline $\begin{array}{l}\text { Decon'd salt soln } \\
\text { Water to SPC } \\
\text { Pecrcle water }\end{array}$ & $\begin{array}{r}14840 \\
922 \\
3820\end{array}$ & $\begin{array}{r}17297 \\
1034 \\
3932\end{array}$ & $\begin{array}{r}16.6 \% \\
12.2 \% \\
2.9 \%\end{array}$ & $\begin{array}{l}3.9 \\
0.2\end{array}$ & $\begin{array}{l}\text { gal/min } \\
\text { gai } / \mathrm{min}\end{array}$ \\
\hline $\begin{array}{l}\mathrm{HCOOH} \text { oSPC } \\
\mathrm{HNOS} \\
\text { Organic resin }\end{array}$ & 21.4 & & & 21.4 & $\begin{array}{l}\text { Ibs/hr } \\
\text { lbs/hr } \\
\text { lbs/hr }\end{array}$ \\
\hline $\begin{array}{l}\text { Zoolite: } \\
\text { Frit } \\
\text { cleses }\end{array}$ & $\begin{array}{l}152 \\
228\end{array}$ & $\begin{array}{r}98 \\
120 \\
267\end{array}$ & $\begin{array}{r}-21.1 \% \\
17.1 \%\end{array}$ & $\begin{array}{r}98 \\
-32 \\
39\end{array}$ & $\begin{array}{l}\text { lbs/hr } \\
\text { bs/hr } \\
\text { los/hr }\end{array}$ \\
\hline
\end{tabular}

The zeolite alternative results in about a $15 \%$ increase in salt solution to $Z$ Area and requires a water removal step to prevent overloading DWPF with the water required to slurry the zeolite from the columns. At $10^{\circ} \mathrm{C}$, approximately $100 \mathrm{lbs} / \mathrm{hr} z e 0 l i t e$ would be fed to the melter. This results in about $40 \mathrm{pph}$ more glass (about 17\%). (Actually, throughput rates, i.e., sludge and salt workoff, would be reduced while canisters required for a given quantity of waste removal would be increased.) The melter feed formulation for this feed is near the liquidus limit. If a high Fe sludge were processed, the glass would probably have to be further diluted to avoid liquidus problems.

If the operating temperature was $40^{\circ} \mathrm{C}$, the zeolite rate would be $274 \mathrm{lbs} / \mathrm{hr}$ resulting in about $70 \%$ more glass (i.e., even further reduced rates and even more canisters). This feed formulation is near the viscosity limit. If high aluminum sludge were processed, the glass might have to be further diluted to avoid viscosity problems.

\subsubsection{Case 4 \\ Organic resin - with acld elution and secondary disposal of the resin}

This alternative is similar to the previous organic resin cases except that after eluting the resin on the last cycle, it is further treated with acid to reduce the activity to a level for alternative disposal methods instead of being fed to the DWPF. This alternative circumvents issues such resin handling issues as mixing, uniformity, process control, and melter redox. 
IX Technology Assessment Report

WSRC-RP-92-1093

A simplified block diagram for this alternative is

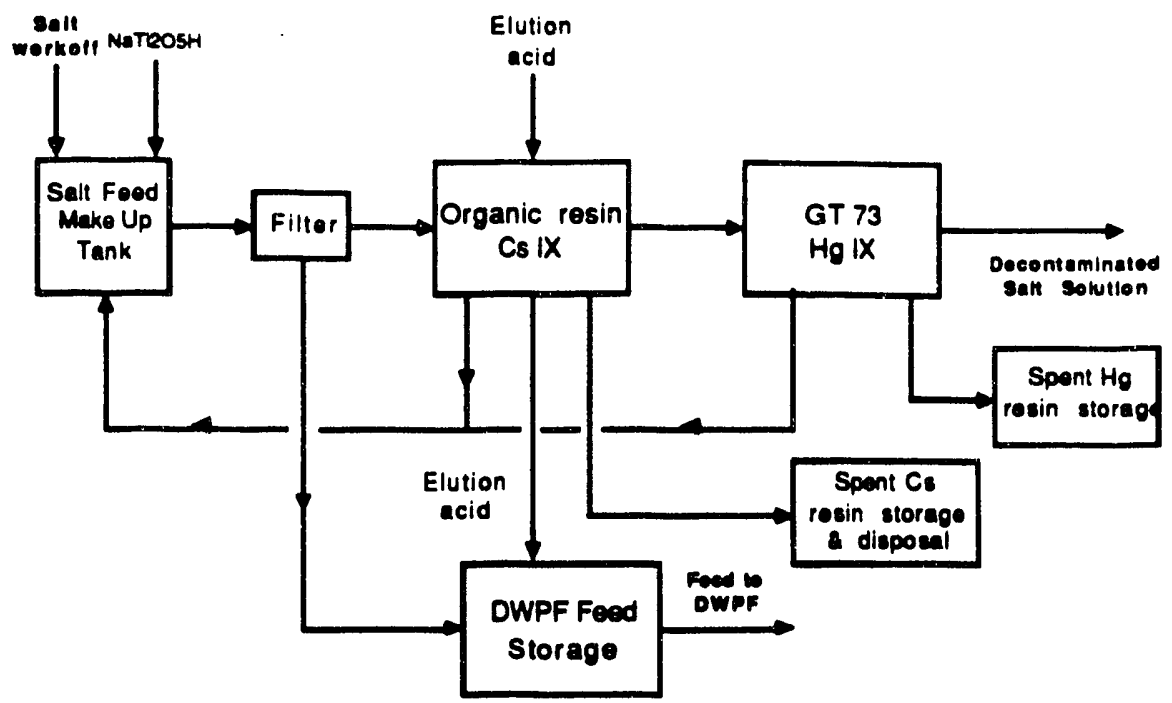

A summary of the primary streams is (flows in $\mathrm{lbs} / \mathrm{hr}$ )

\begin{tabular}{|c|c|c|c|c|c|c|c|}
\hline Description & $\begin{array}{c}\text { Salt } \\
\text { Workoff \& } \\
\text { NaTizO5H }\end{array}$ & $\begin{array}{c}\text { SRS ResI } \\
\text { Salt Makeup } \\
\text { Tank } \\
\text { Recrcle }\end{array}$ & $\begin{array}{l}n \text { - Elut } \\
\text { Cs IX } \\
\text { Input } \\
\text { Streams }\end{array}$ & $\begin{array}{l}\text { Ion with } \\
\text { Cs IX } \\
\text { Elution } \\
\text { Acid }\end{array}$ & $\begin{array}{l}\text { Resin } \\
\text { Hg IX } \\
\text { Input } \\
\text { Streams }\end{array}$ & $\begin{array}{l}\text { Disposal } \\
\text { Decon'd } \\
\text { Salt } \\
\text { Solution }\end{array}$ & $\begin{array}{l}\text { IX } \\
\text { Feed D } \\
\text { DWPF }\end{array}$ \\
\hline $\begin{array}{l}\text { Water } \\
\text { KOH } \\
\text { Na2COO }\end{array}$ & $\begin{array}{r}7879 \\
9 \\
193\end{array}$ & 523 & 925 & 535 & 123 & $\begin{array}{r}8667 \\
9 \\
193\end{array}$ & 778 \\
\hline $\begin{array}{l}\mathrm{Na2SO} \\
\mathrm{NaAl}(\mathrm{OH}) 4 \\
\mathrm{NaNOS}\end{array}$ & $\begin{array}{l}220 \\
398 \\
465\end{array}$ & & & & & $\begin{array}{l}220 \\
398 \\
465\end{array}$ & \\
\hline $\begin{array}{l}\mathrm{NaNOS} \\
\mathrm{N}=\mathrm{OH} \\
\mathrm{C}_{8}\end{array}$ & $\begin{array}{r}1835 \\
575 \\
0.243\end{array}$ & $\begin{array}{r}5 \\
18\end{array}$ & 37 & & $\begin{array}{l}5 \\
2\end{array}$ & $\begin{array}{r}1840 \\
614\end{array}$ & 0.243 \\
\hline $\begin{array}{l}\text { Sir. } \\
\text { Pu } \\
\text { Hg... }\end{array}$ & $\begin{array}{r}1.66 \mathrm{E}-05 \\
1.11 \mathrm{E} .04 \\
0.691\end{array}$ & & & & & & $\begin{array}{r}1.66 E-05 \\
1.11 E-04\end{array}$ \\
\hline $\begin{array}{l}\text { Siluge } \\
\text { Cspos } \\
\text { Hoposes }\end{array}$ & 2.3 & & 2.7 & & 3.6 & & 2.3 \\
\hline $\begin{array}{l}\text { SrRes } \\
\mathrm{NaTi2O} \mathrm{OH} \\
\mathrm{HOOOH}\end{array}$ & 1.3 & & & 24.6 & & & $\begin{array}{r}1.3 \\
24.6\end{array}$ \\
\hline $\mathrm{HNOS}$ & & & & & & & \\
\hline Total & 11579 & 547 & 964 & 559 & 134 & 12406 & 807 \\
\hline
\end{tabular}




\begin{tabular}{|c|c|c|c|c|c|}
\hline & \multirow{2}{*}{$\begin{array}{l}\text { DWPF } \\
\text { Roference }\end{array}$} & \multirow[b]{2}{*}{ CASE 4} & \multicolumn{2}{|c|}{ Change } & \\
\hline & & & Porcent & vol or wt & \\
\hline $\begin{array}{l}\text { Decon'd sah soin } \\
\text { Water to SPC } \\
\text { Recycle water }\end{array}$ & $\begin{array}{r}14840 \\
922 \\
3820\end{array}$ & $\begin{array}{r}12406 \\
778 \\
3676\end{array}$ & $\begin{array}{r}.16 .4 \% \\
.15 .6 \% \\
.3 .8 \%\end{array}$ & $\begin{array}{l}.3 .9 \\
.0 .3\end{array}$ & $\begin{array}{l}\text { gal/min } \\
\text { gal/min }\end{array}$ \\
\hline $\begin{array}{l}\text { HOOOH Q SPC } \\
\text { HNOS } \\
\text { Organic resin }\end{array}$ & 21.4 & 24.6 & $15.0 \%$ & 3.2 & $\begin{array}{l}\text { los/hr } \\
\text { lbs/hr } \\
\text { lbs/hr }\end{array}$ \\
\hline $\begin{array}{l}\text { Zoolite"' } \\
\text { Fris " } \\
\text { Gass }\end{array}$ & $\begin{array}{l}152 \\
228 \\
\end{array}$ & $\begin{array}{l}160 \\
228 \\
\end{array}$ & $5.3 \%$ & 8 & $\begin{array}{l}\text { lbs/hr } \\
1 \mathrm{bos} / \mathrm{hr} \\
\mathrm{lbs} / \mathrm{hr}\end{array}$ \\
\hline
\end{tabular}

This case is essentially the same as the elution cases except that slightly more formic acid is used (but still similar to the reference amount) and no resin is fed to the melter avoiding several concerns about processing organic resins in the DWPF. Reductions in water to the SPC and salt solution to $Z$ Area are approximately the same as the other elution cases.

\section{SECTION 3 - ATTACHMENT 1}

\section{pH ADJUSTMENT OF SIMULATED SRS SUPERNATE}

A $5 \mathrm{~mL}$ sample of simulated SRS supernate was pH adjusted to 9 using $10 \%$ HNO3. This required $4.5 \mathrm{~mL}$ of acid, giving a total final volume of $9.5 \mathrm{~mL}$. If $50 \%$ HNO3 is used, the volume needed should be $0.9 \mathrm{~mL}$ of acid. That would increase volume $18 \%$.

The precipitate that formed was removed by filtration through a weighed $0.45 \mu \mathrm{m}$ filter. The precipitate and filter were oven-dried at $100^{\circ} \mathrm{C}$ for $18 \mathrm{hrs}$ and then reweighed to constant weight. The mass of solids, which still contain bound water, was $0.4735 \mathrm{~g}$. This computes to $0.8 \mathrm{lbs}$ of solids per gallon of supernate processed. These solids would have to be separated and, probably, washod.

The filtrate was sent for ICP scan (attached). It should be noted that just about everything precipitates and is removed from solution. The sodium and cesium ions would remain in solution.

The filtrate was then pH-adjusted again to 9.5 using $1 \mathrm{M} \mathrm{NaOH}$. This step required $0.18 \mathrm{~mL}$ of caustic. In practice, SRS would probably use $19 \mathrm{M} \mathrm{NaOH}(50 \%)$, a process which would require $4.0 \mathrm{~mL}$ of caustic for every gallon of diluted, filtered supernate adjusted. 
IX Technology Assessment Report

WSRC-RP-92-1093

Issues:

1. Filtration of the precipitate will not be trivial.

2. The throughput for the sorbants can be approximated from the equation $\mathrm{Kd} \mathrm{r}^{*} \mathrm{r}=$ column volumes of throughput at $50 \%$ breakthrough

Kd"r for the SRS resin is about 200 , or $\sim 0.015$ Ibs of resin/gallon of feed

Kd*r for IE-95 is about 18.5, or $\sim 0.25 \mathrm{lb}$ zeolite/gallon of feed.

Can glassmaking accommodate either of these amounts of substrates? (These are oncethrough numbers)

3. Precipitate will have to be washed before saltstone could take it. This will mean more water. 


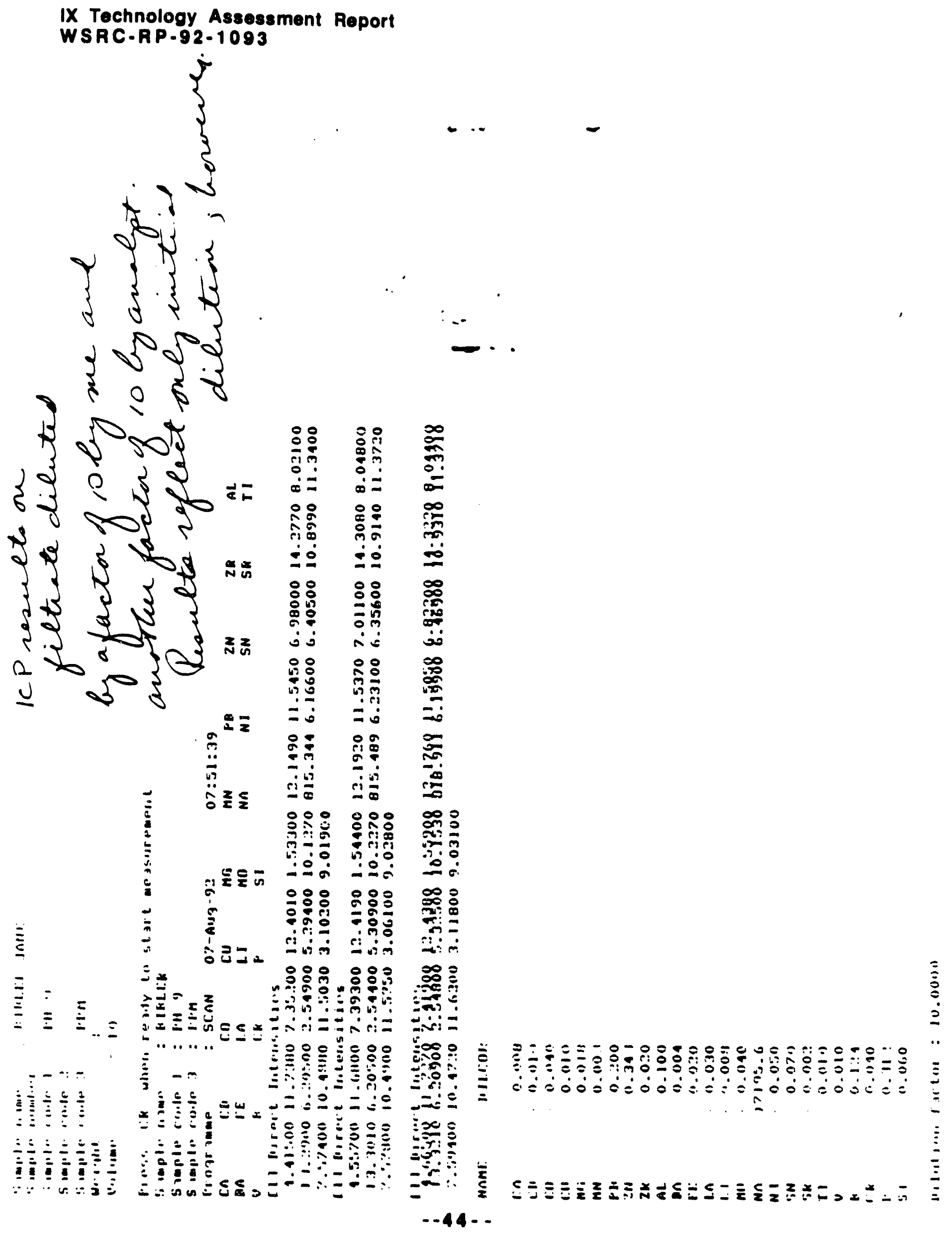




\subsection{References}

1. Howden, M., "Radioactive Effluent Treatment Plant-Sellafield Reprocessing Factory", Proceedings of the Institution of Mechanical Engineers, Volume 200 No. 85, pp 1-15, 1986.

2. Bray, L.A., presentation to the IOn Exchange Technology Task Team, SRS, August 18-19, 1992.

3. Bray, L.A., Carson, K.J., Elovich, R.J., Kurath, D.E., "Batch Distribution Data for CC and NCAW Wastes as a Function of the $\mathrm{Na} / \mathrm{Cs}$ Mole Ratio, Temperature, and $\mathrm{Na}+$ Concentration", August 1992, in review.

4. Baum, R., "Cesium Cut from Radioactive Waste", C\&EN, p 26, July 13, 1992.

5. Wallace, R.M., personal communication to J.P. Bibler.

6. Prout, W.E., Russell, E.R., and Groh, H.J., J. Inorg. Nucl. Chem., 27, 473 (1956).

7. Dyer, A., "Recent Advances in Inorganic lon Exchangers", Recent Developments in lon Exchange 2, Williams, P.A., and Hudson, M.J. eds, Elsevier Applied Science Press, 1990, p 43.

8. Hudson, M.J., Rodriguez-Castellon, E., and Sylvester, P., "Ion Exchange Behaviour of some Amirie Intercalates of a-Tin(HPO4)2n, Recent Developments in lon Exchange 2, Williams, P.A., and Hudson, M.J. eds, Elsevier Applied Science Press, 1990, p 109.

9. Ferragina, C., La Ginestra, A., Massucci, M.A., P. Cafarelli, P.Patrono, P., and Tomlinson, A.A.G., "Formation of Diamine-Complex Pillars in 1-Ti(HPO4)2", Recent Developments in lon Exchange 2, Williams, P.A., and Hudson, M.J. eds, Elsevier Applied Science Press, 1990, p 103.

10. Wallace, R.M., "Duracil" file, in B-132, 773-A Savannah River Technology Center.

11. Bibler, J.P., and Wallace, R.M., "Preparation and Properties of a Cesium Specific Resorcinol-Formaldehyde Ion Exchange Resin", DPST-87-647, 1987.

12. Bray, L.A., "Cesium Recovery Using Savannah River Laboratory ResorcinolFormaldehyde Ion Exchange Resin", PNL-7273/UC-510, March 1990.

13. Campbell, D. O., Lee, D.D., and Dillow, T.A., "Low-Level Liquid Waste Decontamination by Ion Exchange", ORNLTM-11789, 1990, and Proceedings of Waste Management '90. Tucson, AZ, p 389.

14. Bibler, J.P., "A comparison of Juolite" $\mathrm{m}$ CS-100 and SRS Resorcinol/Formaldehyde lon Exchange Resins with Three High-Level Waste Simulants Before and After g-Irradiation (U) ${ }^{n}$, WSRC-RP-91-1221 December 11, 1991.

15. Bibler, J.P. and Wallace, R.M., "Mercury Removal from Supernate Using lon Exchange", DPST-84-848, October 30, 1984.

16. Bibler, J.P., "EP-Toxicity Test of Saturated GT-73 Resin and Resin in Grout", DPST85-446, April 24, 1985. 
IX Technology Assessment Report

WSRC-RP-92-1093

17. Bibler, J.P., "TCLP Test Results for $\mathrm{Hg}, \mathrm{Cr}(111)$, and $\mathrm{Pb}$ on GT-73 Cation Exchange Resin", DPST-87-811, Nov. 13, 1987.

18. Walker, D.D., and Wallace, R.M., "Technical Data Summary for Ion Exchange Removal of Strontium", Memorandum to L.F. Landon, Ostober 27, 1988. 
IX Technology Assessment Report

WSRC-RP.92-1093

\section{DEVELOPMENT PROGRAM}

\subsection{Technical lssues, Uncertaintles, and Needs}

The principal bases for the ion exchange process development program are the technical issues and uncertainties, listed below as presently understood. Of course, any development program will be to some extent "results-driven"; i.e., the program will be modified if new issues and uncertainties arise from the R\&D itself.

In a sense ion exchange is already better understood than the reference precipitation process (ITP), having been used at other nuclear sites for the removal of Cs and other ions from waste streams. The recommended resorcinol resin has been fairly well characterized with SRS salt waste chemistry and tested with real waste, and a large scale (three 80-gallon columns) skidmounted demonstration unit is currently being installed at TNX for testing. However, in terms of integration with other SRS waste facilities such as DWPF, Saltstone, and waste storage/removal, ion exchange is relatively undeveloped.

The recommended ion exchange process has been designed, in part, 10 minimize technical uncertainties. Thus zeolite is not recommended, not only because of its relatively low $\mathrm{Kd}$, but also because a major new process step (pH adjustment and aluminum precipitate removal) would require development, and major glass questions would arise. Likewise, for the recommended resorcinol resin, all technical concerns about resin compatibility with the SRAT/SME as well as with the melter are eliminated by using acid elution and by specifying the disposal of spent resin as LLW. This approach maximizes the technical assurance of ion exchange and minimizes the time needed to bring it on line without, in our judgment, seriously increasing the equipment or operational complexity.

Equipment design uncertainties are not generally listed here, although equipment development will be a major part of the overall program. Development of such items as valves, pumps, and instruments will be design-driven and will be incorporated and tested in large scale and/or hot cell facilities and demonstrations. No "inventions" or unusual equipment applications are required. However, it must be noted that a prefiltration device is yet to be defined, and considerable development may be neoded.

Appendix $D$ contains details about some of the key uncertainties.

A process development and verification logic/decision flow diagram has been developed and is attached as figure 4.1.

\subsubsection{Major Tochnical lssues}

There are no scientific or feasibility issues about radiocesium ion exchange, mercury ion exchange, strontium and plutonium removal, or filtration; or about the application of these processes to SRS salt waste.

\subsubsection{Safoty losues}

There are no special safety issues associated with ion exchange. Cesium, plutoniumuranium, and mercury are hazardous materials. IX introduces no flammable or other chemical hazards other than acids and bases. 
IX Technology Assessment Report

WSRC-RP-92-1093

4.1.3 Recommended Process Confirmation: Technical Noeds

1. Feed Characterization/Blending Schedule (also needed/being addressed for ITP)

2. Prefiltration (See also Appendix D)

- sludge and titanate solids characterization, filterability

- IX column feed spec. on solids

- candidate filter performance

3. Resin Transfer/Handling

- attrition, fines generation and removal

- slurry rheology

- $\quad$ minimum water requirement

4. Cesium Elution Acid

- selection

- SRAT acid balance, chemistry

- melter effects, carbon or NOx

5. Spent Resin Decontamination Requirements, Storage (packaging) Requirements, Disposal Interface Technology

6. Process Integration (through melting) Demonstration

4.1.2 Transition Process Definition: Technical Needs

1. IX Resin Performance (dissolved TPB feed) - possibly several candidate solvents. Solvent selection.

2. Disposal of Decontaminated saltorganic solution (See also Appendix D)

- interim storage: stability and corrosivity

- incineration option - CIF acceptability

- saltstone option

- other disposal options

3. Fate of dissolved diphenyl mercury.

4. Dissolution/fate of actinides and Sr.

4.1.3 Retorence Process Improvements and Fallbacks: Tochnical Noeds

1. Mercury Simplification (Delete GT-73 column. See also Appendix D)

high $\mathrm{Hg}$ Saltstone performance assessment (geohydro. modeling)

2. Column Removal of $\mathrm{Sr} / \mathrm{Pu}$ (fallback)

media selection (performance); include titanate-coated resin

media
elution 
IX Technology Assessmont Report

WSRC-RP-92-1093

- $\quad$ spent media disposition

- criticality

3. Resin to DWPF/Melter (once-through loaded or spent resin)

resin grinding requirement

- resin physical/chemical compatibility with SRAT/SME/MFT

- loaded resin lag storage: heat removal, degradation, corrosivity

- melter carbon tolerance

4.1.4 Other Processes and Modia: Issues and Opportunities

1. Decoupling IX from DWPF (See also Appendix D)

- Cesium-only glass issues (disposal requirements, glass formulation, loading/\# of canisters, process)

long term resin or secondary media storage issues (heat, degradation, corrosion, volume)

2. Technetium removal by IX (Saltstone Enhancement)

process details (resin technology exists)

3. Continued Testing/Evaluation of Advanced Media

e.g., silicotitanates 
IX Technology Assessment Report

WSRC-AP-92-1093

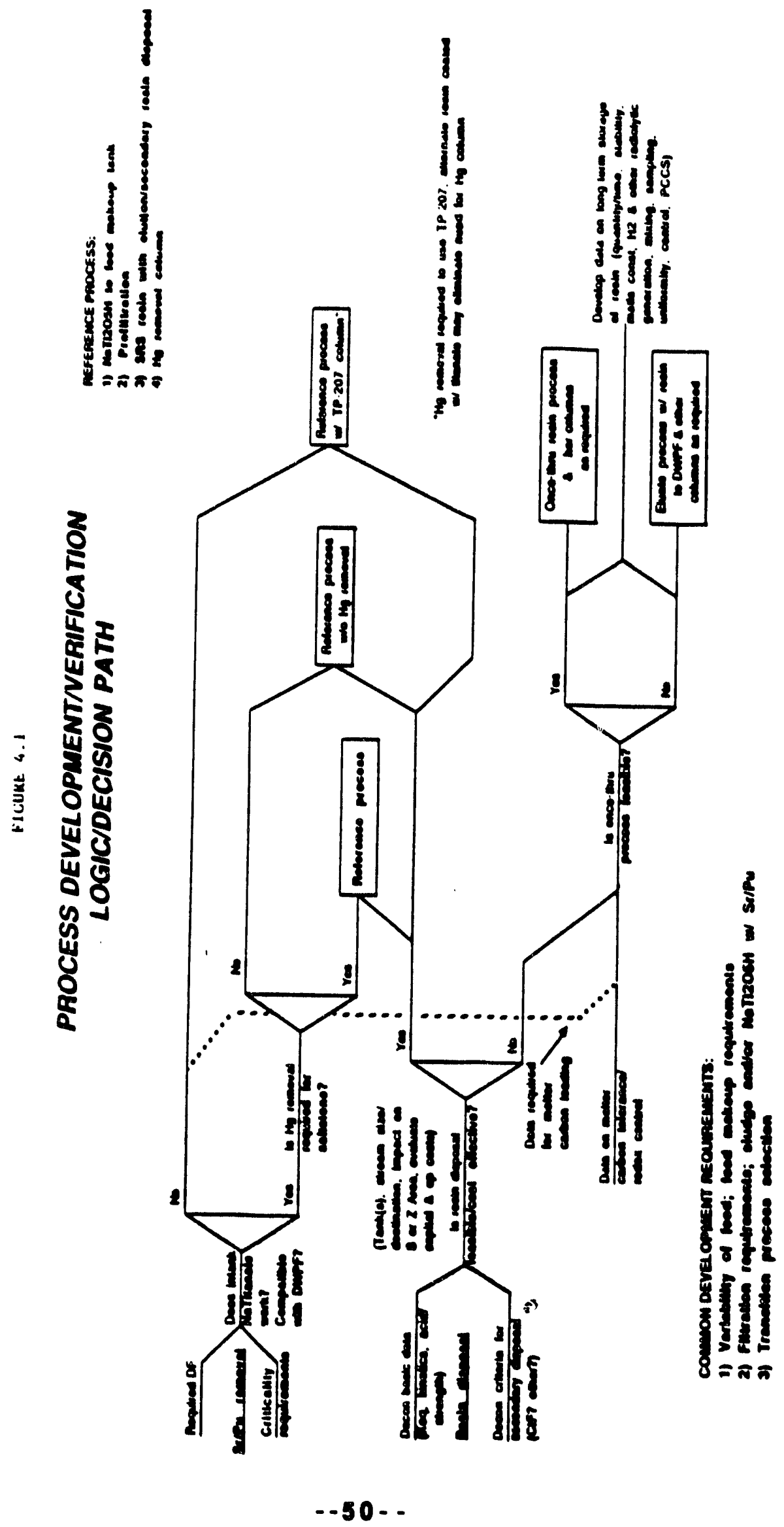




\section{2 Scope, Schedule, Manpower, Where}

This development program addresses all the issues that have been raised about technical needs associated with an IX process. The program and the attached, published schedule has been amended to include additional tests that the task team has identified for program integration of ion exchange. All of the addert tasks can be carried out concurrently with the tasks identified in the original sequence diagram if personnel and funds are available. The original nomenclature associated with the sequence diagram has been retained. The bold type at the right margin of the report indicates the place at which the work could most expeditiously be done. IDMS runs are scheduled around Late Wash research runs and down time for cleaning the melter.

Rearrangement of priorities, selection of a process (elution vs once-through), and commitment of personnel and funds would compress Phases 3 and 4. SRS personnel have strongly recommended including Tc-99 removal if cost-effective. This technology is well-demonstrated for Tc-99 removal from a high nitrate, caustic waste.

\section{PHASE 1: Installation of SKID at TNX}

1A-Installation $\quad 6 / 1 / 92-2 / 1 / 93$

SRS

- Construct resin loading facility

- Write procedures, task plan

- Arrange any needed environmental permits

- Purchase resin and cold chemicals

$1 A^{\prime}$-Development - Concurrent with $1 \mathrm{~A}$ MOST URGENT 9/1/92 - ?

- Characterization of waste

- Determine need for filtration and identify filtration process HLC test with real waste

- Corrosion/radiation studies 9/1/92 - 4/93

- Corrosion

- Gaseous product characterization

- Soluble organic byproducts

- Kd changes

- Mass changes

- Minimelter/crucible/small SRAT studies; must include one hot run in HLC 9/1/92 - 9/93

- TPB dissolution and reload on IX 10/1/92 - 10/1/93

PNL

- Characterize treated waste stream for disposal

- Disposal options

- HLC demo of three resins in series with real waste

- DP, DF's, fate of Pu 
2A - Checkout of SKID 2/1/93 - 5/1/93

- Resin fines separation tests

- Training

- Water runs

- Resin handling, pumping, etc.

$2 A^{\prime}$ - Concurrent resin studies 10/1/92 - 10/1/93

Small scale ( $200 \mathrm{~mL}$ columns)

PNLWH

- Loading/unloading kinetics

- Temp optimization

- K,Rb effects

- Type and conc. of acid for elution

- Flow rate studies

PHASE 3: IX Studies on SKID

1C-2-SKID studies 5/1/93 - 11/93

SRS

- Once-through(a) and regeneration runs

- Generate Cs product for IDMS using PNL optimum from 2A'

- Three resins(b) and simulant, 1 per column study..... DP

PHASE 4: IDMS Integration

4A - Melter runs

- Purex waste

SRS

- HM waste

- Noble metals waste

- Eluant added

- Offgas characterization

PHASE 5 ?: Integration of Secondary Wastes - Storage, saltstone, CIF, ETF Include TC-99 removal by IX in processI

a If elution and sodium titanate addition are selected, only two resins in series will be tested for hydraulic properties, resin in the melter will not be an issue to be tested, and all the tests to make the resin compatible with the melier feed and glass will not be needed.

b If it is determined that Hg-removal is not necessary and the sodium titanate is used in the front of the process, this test is not needed. 


\section{COST SUMMARY}

Equipment Purchase

Phase 1: Installation

- Install Unit

- Procedures and Task Pians

- Permitting (environmental)

- Purchesse Resins and Cold Chemicals

- Fabricate Resin Loading Facility

- TNX/Bechtel Engineers

- Programmatic Personnel
$\$ 350 \mathrm{~K}$

$\$ 3,700 K$

$\$ 700 \mathrm{~K}$
$\$ 2,400 K$
$\$ 200 \mathrm{~K}$
$\$ 200 \mathrm{~K}$
$\$ 200 K$

Phase 1 Concurrent:

- Characterization of waste (sngoing)

$\$ \ldots . .$.

$\$ 1,700 \mathrm{~K}$

- Filtration Studies (6-12 months)

$\$ 200 K$

- Radiation/Corrosion studies (1 man year)

$\$ 400 K$

- Minimelter/crucible/small SRAT studies (2 months) $\$ 200 \mathrm{~K}$

- 3 Col. operation in HLC w/supernate (2months)

- TBP dissolution and reload on IX (12 months)

$\$ 150 \mathrm{~K}$

$\$ 150 K$

- Programmatic personnel

$\$ 600 K$

Phase 2: Checkout (2 months)

$\$ 300 \mathrm{~K}$

- Resin handling tesis

- Equipment safety review

- Water runs

- Personnel training

- Programmatic personnel

$\$ 300 K$

Phase 2 Concurrent

- Small Column and batch tests at PNLWH \$200K

$\$ 200 K$

Phase 3: 1X Testing i INX (9 months)

$\$ 2,000 \mathrm{~K}$

- Loading tests

- Regeneration tests and resin life*

- Waste disposal

- TNX and programmatic persunnel

Phase 4: IDMS Inteoration (19 months)

- SRAT/SME processirig

- Processing Purex, HM sludge

- Sampling demonstrations

- Mixing characterizations

- Glass quality verification

- Homogeneity testing w/wo frit

- TNX and programmatic personnel $\$ 10,850 \mathrm{~K}$

TOTAL

$\$ 18,750 \mathrm{~K}$

- This number represents a maximum and may be reduced as the total essential number of IDMS runs is determined. A minimum of 3 IDMS runs may be all that are essential, though as many as 8 may be needed. 


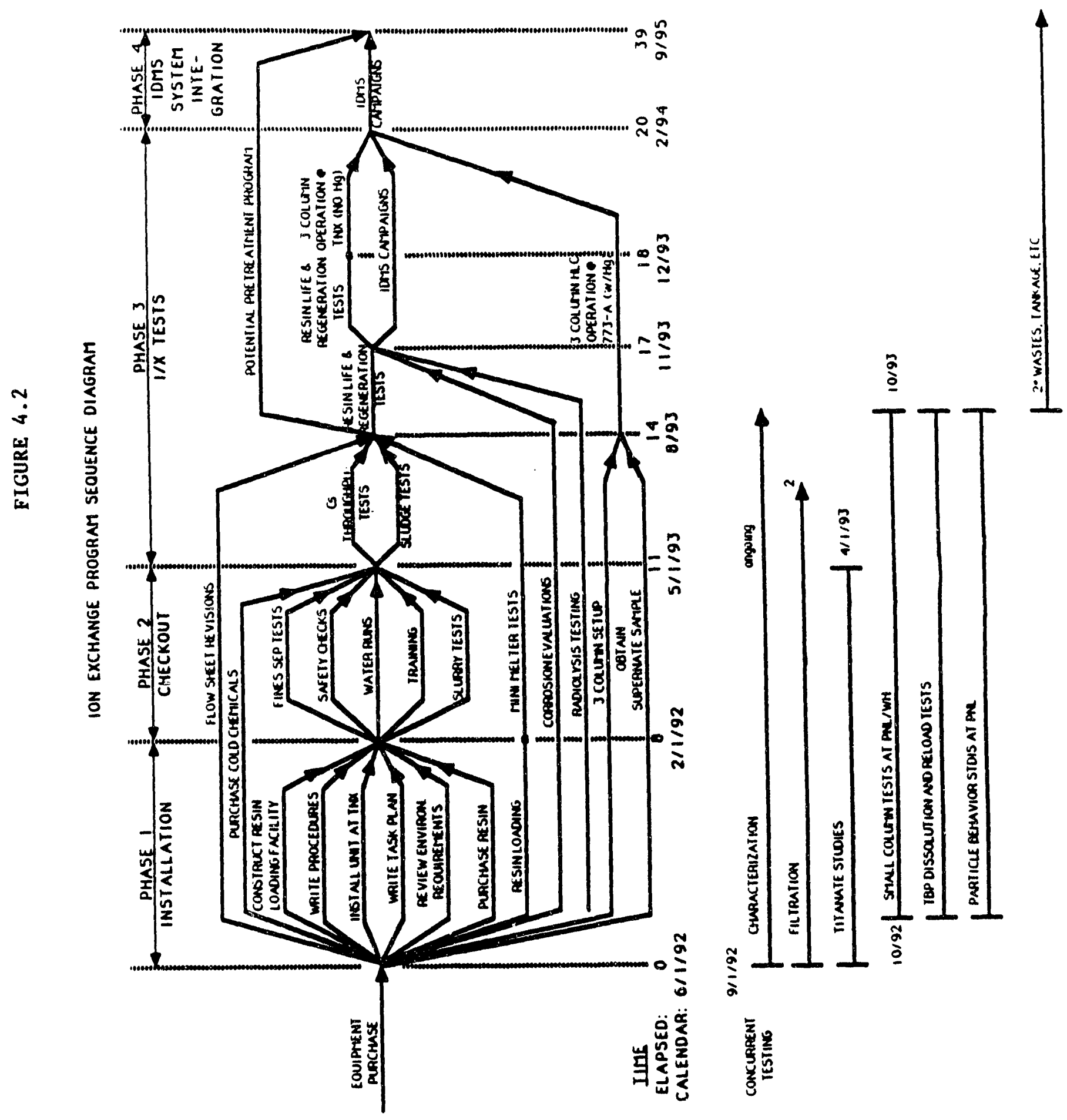




\subsection{Regulatory Requirements}

\subsubsection{Permits}

Permits should not have significant impact on cost and schedule for this facility. Application for new or modifications of the existing permits should begin immediately after the conceptual design since they are needed to start construction. Maximum time allocated for any of the permits in the attached schedule is twelve months. It was assumed that only an Environmental Assessment would be required under National Environmental Policy Act (NEPA). If an Environmental Impact Statement is required, it would add an additional 3-5 years to the schedule. Following are the significant permits required for construction of the facility:

- Modification of DWPF Industrial Waste Water Permit

- Modification of DWPF Air Permit

- Modification of DWPF Industrial Waste Water Permit

- Modification of Tank Farm Air Permit

- NEPA Environmental Assessment

- Modification of $Z$ area Industrial Waste Water Permit

- Modification of $Z$ area Air Permit

\subsubsection{Codes, Standards and Orders}

Codes, standards and DOE orders required for the design of the faculty would be identified in the Functional Design Criteria. Except for DOE Order 4700.1, they should not significantly impact the cost and schedule for the facility. If the DOE requires that ion exchange be developed as a new project, application of DOE Order 4700.1 could have a significant impact on the schedule due to funding delay. In developing the high priority schedule, it was assumed that ion exchange would be funded as an addition to the existing S-1780 project. This assumption is consistent with the proposed funding of Late Wash.

\subsection{Schedule}

Base case and compressed schedules were developed for the ion exchange process. Base case schedule would follow path of a normal (4700.1) project while the compressed schedule is based on the path of the Late Wash Project (S-1780). Following are the assumptions used in the preparation of the compressed schedule:

- Ion Exchange would be funded as part of the existing project

- Detailed design would start after Phase III of R\&D

- Permits would be obtained before beginning construction

- Construction duration is based 24 hour/day and 7 day/week operation

- Construction duration was obtained by comparison with the manhours for construction of ITP

Following are the assumptions used in the preparation of the base case schedule:

- Ion Exchange would be funded as part of the existing project

- $\quad$ FPR would be started after the completion of Phase IV research program 
IX Technology Assessment Report

WSRC-RP-92-1093

- Permits would be obtained before beginning construction

\subsection{IDMS Avallability}

The IDMS facility is scheduled to shut down in order to clean the melter to extend its life. That should take place within the next six months, according to Joe Carter of DWPT. Before that time he hopes to make 1 or 2 late wash runs if the melter holds up. We will go to Hanford next week to talk to Bill Appel about the runs they want. He also has to fit IX runs in. All of this work can be shifted in priority with word from management. 


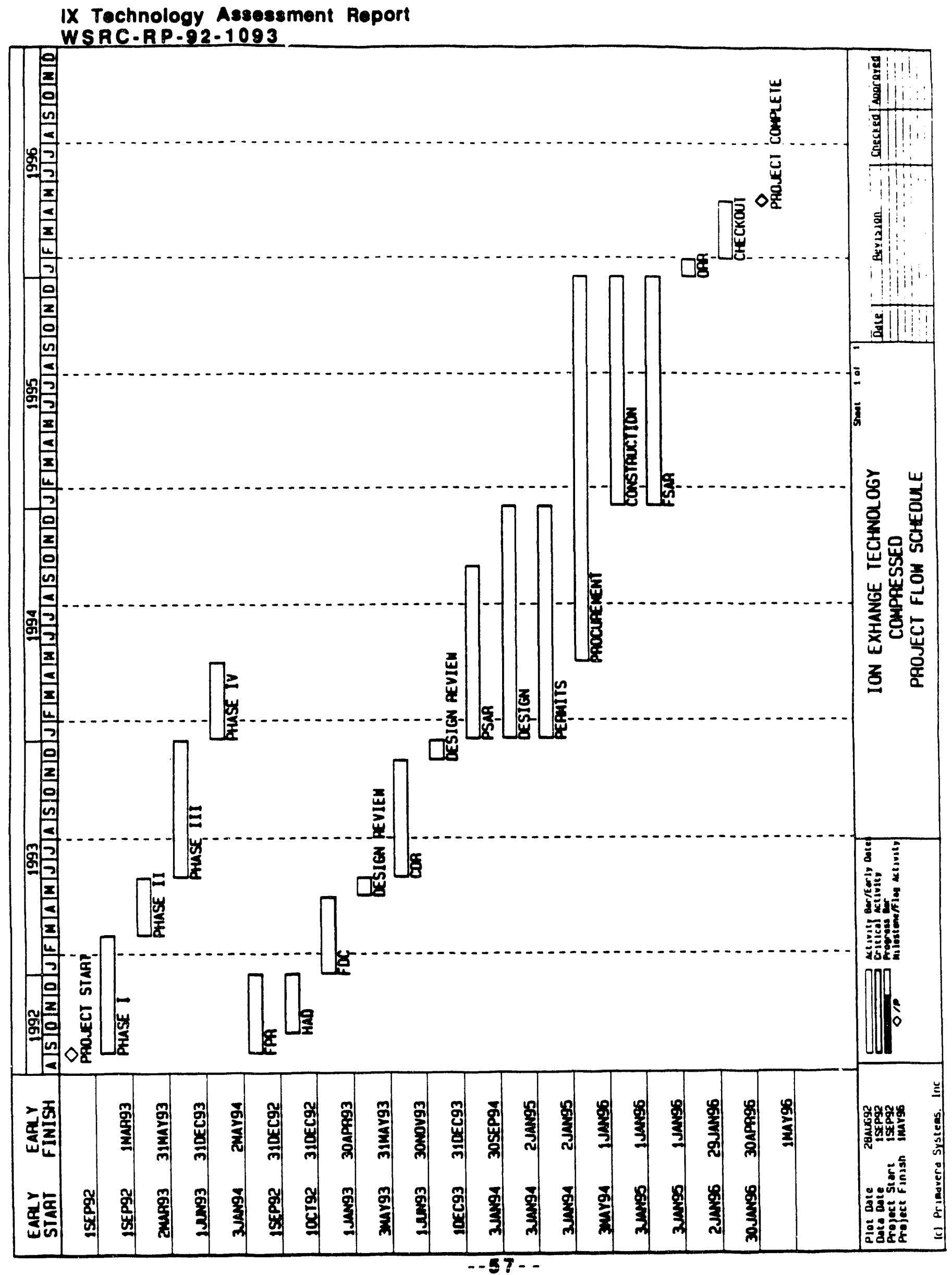


IX Technology Assessment Report

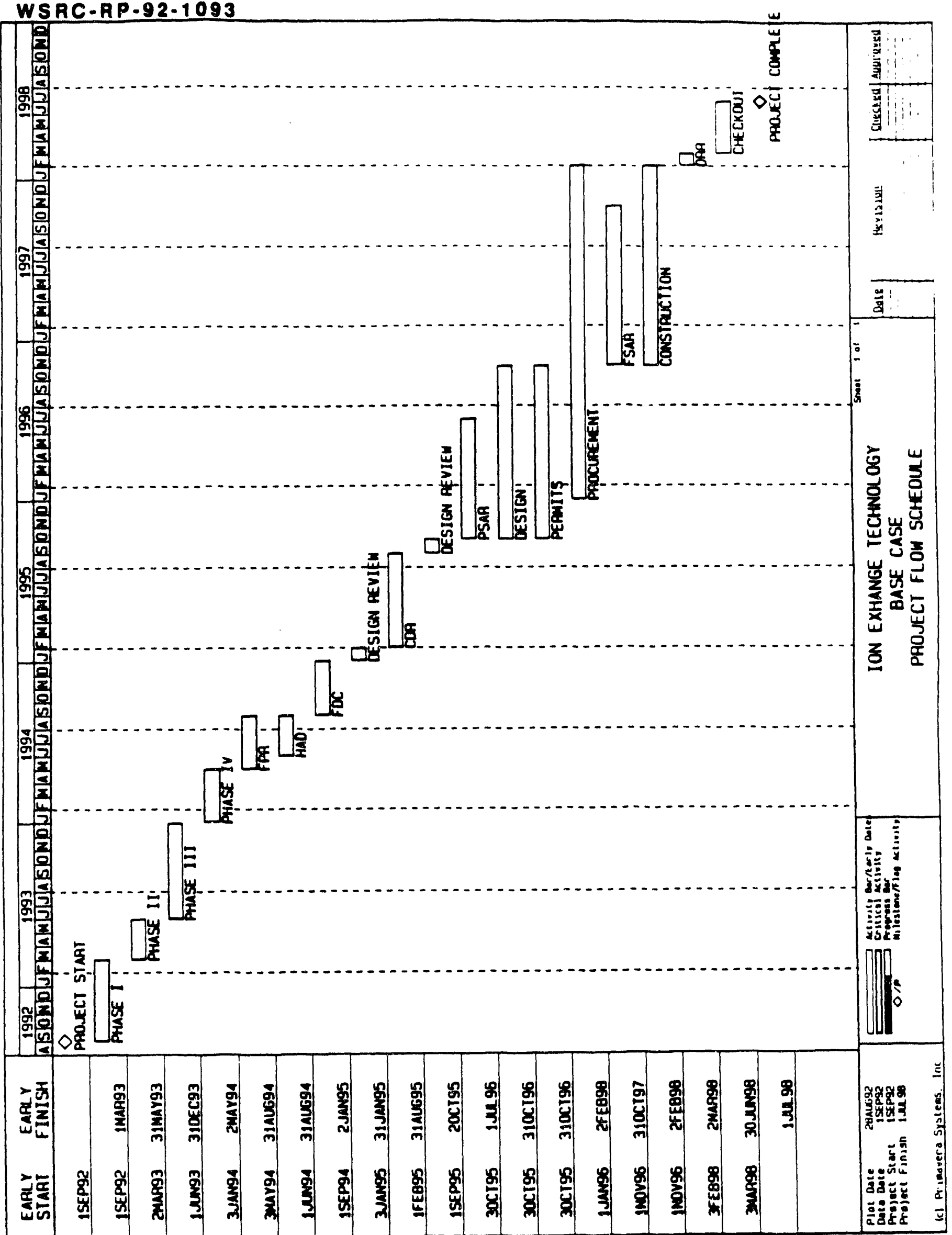




\section{CONCLUSIONS AND RECOMMENDATIONS}

\subsection{IXBACKGROUND}

IX processing has been long known to be an applicable technology for SRS wastes; for example, it is found in the DWPF 1982 EIS.

In-tank precipitation (ITP) was chosen because (1) existing tank farm vessels could be used versus much higher costs for a new IX facility, and (2) candidate resin performance had not yet been advanced to today's efficiencies.

The Late Wash process added to ITP removes nitrite and water soluble organic compounds resulting in improved performance in precipitate hydrolysis and subsequent DWPF processes, thereby yielding a viable current reference flowsheet.

\subsection{XPROCESS TECHNOLGY}

IX processing technology can treat SRS HLW salt solutions, sludge washes and apparently ITP product to meet DWPF and saltstone feed criteria. A team of experts from SRS and other sites was convened for two intensive workshops in arriving at this conclusion.

The IX process proposed utilizes sodium titanate addition to adsorb/separate $\mathrm{Sr}$ and $\mathrm{Pu}$; a filter to remove sludge and titanate solids; and an SRTC developed resin to remove Cs, which is eluted with formic or nitric acid and fed to the DWPF along with the titanate/sludge solids. Spent resin is decontaminated for low level waste disposal.

GT-73 resin is included to capture $\mathrm{Hg}$ to compare to historical practice, but this may be unnecessary; its elimination could represent a significant process simplification.

The IX high-activity product is compatible with DWPF chemistry and glass qualification. The resin is eluted and not sent to the melter. Sodium itanate is the same as for ITP/PHA. The acidity is comparable. There is no mercury or aromatic hydrocarbon. Most importanily, there are relatively small amounts of boron and the alkali species $\mathrm{K}$, and $\mathrm{Na}$ in the IX product, making it more forgiving in terms of glass chemistry, and potentially providing an opportunity for higher cesium loadings in glass (as well as higher saltcake and salt solution workoff rates).

The IX process appears to decrease the quantity of decontaminated salt solution by approximately $15 \%$ as a result of less added water compared to ITP and LW.

There are other IX media and permutations which are also feasible, but presently these flowsheets have relative disadvantages to the proposed IX process.

Other sites have chosen different IX media as a result of different waste characteristics such as $\mathrm{pH}$ or species concentrations.

\subsection{XXDEFLOPMENT PROGRAM}

Since the selection of ITP, IX experience has been increasingly demonstrated by West Valley, BNFL, Hanford, etc., such that it is currently better understood than ITP. Thus, a development program is needed, but not as if IX were a new technology nor one as challenging in terms of processing or chemistry as ITP. 


\section{Technology Assessment Report \\ WSRC-RP-92-1093}

The IX development program includes relatively few primary issues to be resolved:

1) sludge and titanate filtering characteristics and equipment before $I X$, and resin fines filtration after IX (although this is less worrisome than ppt filtration);

2) dissolution of the ITP precipitate enabling treatment by IX and treatmentdisposal of the decontaminated organic solution from this flowsheet.

3 ) IDMS verification of no unexpected melter feed makeup, vitrification, off gas, etc. behavior.

The total IX development cost is estimated at about \$4M for TNX pilot system installation, chemicals, etc. and \$2M each for its operation and SRTC/PNL support testing; and as much as an additional $\$ 11 \mathrm{M}$ for comprehensive IDMS runs which would include noble metals, etc.

All IX developmentpilot work is estimated to be completed in 17 months; followed by up to 19 months of IDMS and full-size SRAT/SME tests. This latter comprehensive testing program has extensive verification for DWPF and can be reduced if $I X$ is shown as expected to be nonimpacting to the vitrification operation or the process/product qualification to the Waste Acceptance Criteria.

\subsection{PROGBAMMATICINIEBEACES}

A consensus perspective of the IX Technology Assessment Team is that the functional performance criteria can be specified today and design initiated; it should be possible to accommodate open issues such as filtration without excessive cost for this flexibility. However, programmatic considerations summarized below strongly support the processing of SRS tank farm HLW by ITP/LW as opposed to delaying until an IX system is on-line.

Three overriding critical programmatic commitments have been identified by WSRC/DOE (ref. W. B. Boore report):

1) The near term need to produce tank farm HLW volume capacity from vintually full tanks can only be achieved by ITP operation;

2) The radioactive operation of DWPF by $6 / 94$; and

3) Extremely limited funding essentially precludes significant IX work unless a new source of funding is found.

The precipitate treatment to prepare it for DWPF feed is currently most clearly addressed by Late Washing as it is well along in design and testing; conversely, using precipitate as IX feed presents the most unknowns at this time.

IX will most likely need facilities such as significant permitted tankage which will be critical path (EIS) requiring 5+ years thereby precluding $I X$ in the near term. The implementation of ITP/LW appears to be the most effective means to provide such tanks in the long term.

Given the SRTC and IDMS priority support required for DWPF Cold Chemical and Qualification Runs, as well as ITP/LW, IX is most appropriately a backup technology. 
Key potential drivers (advantages) to support the commitment to IX's role include:

1) Maximizes DWPF operability and attainment by providing "forgiving" (very acceptable) feed and in quantities to support the DWPF design basis throughput capability.

2) Otfers the possibility to minimize the number of canisters produced because less B/less alkali/higher Cs can be delivered with attendant cost reductions;

3 ) Reduce other costs in terms of eliminating benzene and its treatment, resin of a cost lower than NaTPB, less secondary Hazardous waste, etc.

4 ) Provides a high confidence back-up or "next generation" process.

5 ) Results in a $15-20 \%$ reduction in saltstone.

6 ) Simplifies the operational, control and safety strategies for DWPF because hydrocarbons and flammable species are eliminated.

"Tradeoffs" to these potential advantages are:

1) Cost and time to provide permitted tankage (e.g., type III) and major canyon facilities, even if there is retrofit into an existing canyon such as " $F$ ".

2) Disposition of spent resin, i.e., storage of the spent resin as low level waste.

3) A process to deal with ITP precipitate feed as well as the organic effluent.

\subsection{Becommendations}

- Perform an Engineering Evaluation starting immediately to better quantify the process flow diagram, equipment sizing/lists, prospective locations, criteria necessary $(4700.1$, 6430.1Avetc.), permits, schedules, etc.

- Ensure that the interface requirements or operational strategies of DWPF and Saltstone are addressed.

- Incorporate the alternatives studies results being generated from Hanford's assessments of technologies and various operating strategies.

- Conduct an economic tradeoff study to determine the incentives for implementing IX as the next generation process given the costs to decontaminate the precipitate hydrolysis process, Late Wash, etc., compared to the benefits from full DWPF attainment, reduced canister numbers, etc. projected for IX.

- The development program identified should be supported in parallel with the reference program activities because:

1) IX would represent a backup to ITP/LW/PH should any unexpected difficulties with filtration, ammonium nitrate formation, precipitate hydrolysis, etc., arise during the full scale, integrated DWPF Cold Chemicals runs. 
2) The development program will support the engineering study such that design questions are addressed in a timely manner.

- Evaluate a proposal to apply IX directly to DWPF Recycle and Sludge Washwater streams.

- Continue an active interchange program with Hanford, West Valley, PNL and other sites such as National Laboratories who have experience in or the need for treatment of Cs, $\mathrm{Sr}, \mathrm{Pu}$, etc., in wastes of the types to be treated at SRS.

- SRTC should request OTD funding to lead an Integrated Technology Demonstration of IX, indicating that a pilot unit has already been purchased and much preliminary support testing completed. Alternatively, a direct arrangement with the National Laboratories and Hanford should be pursued where cost shared testing yields highly cost effective results. 
IX Technology Assessment Roport

WSRC-RP-92-1093

\section{APPENDIX A}

\section{KEY REQUIREMENTS FOR FEED TO Z-AREA}

\section{Z-AREA PROCESS LIMITS}

As presently planned, Z-Area will operate on the basis of a single shift, with occasional overtime, to process the projected annual volume of 8-9 million gallons of wastewater from the Effluent Treatment Facility (ETF) and the F/H Tank Farms. In theory, up 1020 million gallons/year of wastewater could be processed through a multiple-shift operation in Z-Area, but sustaining this high production rate over an extended period would require a major upgrade in the dry materials handling and storage system, in addition to an accelerated schedule to construct vaults.

At the 8-9 million gallons/yr rate, a disposal vault will be filled approximately every 15-18 months. Each cell in a vault is sized to receive the saltstone produced from 1 million gallons of wastewater sent to Z-Area. Saltstone can only be produced if a vault is available for disposal, and the ability to construct vaults at the projected disposal rate will dictate both the annual cost of disposal and the ability to process waste as it is produced. The ability to receive and unload dry materials at the rate needed to maintain higher production rates is a second limiting factor of the Z-Area process.

Based on the existing soluble HLW waste inventory, about 94 million gallons of Z-Area feed will be generated by the ITP process, if it is used to decontaminate the HLW. This estimate includes waste to be generated from both recycle from the DWPF and in-tank sludge processing, but does not include an estimated 1 million gallons/year that is also expected to be generated by ETF. Because disposal is based on the volume (not the mass) of wastewater sent to Z-Area, the relative cost of disposal in Z-area for any process can be estimated by simply comparing the relative effluent volumes generated by the respective processes. Due to uncertainties in the estimated HLW inventory, in the DWPF recycle volume and composition, and in volume and salt content of waste generated in sludge processing, a difference of $15 \%$ in the relative volumes should not be considered as significantly different.

From the standpoint of Z-Area operations, 6 specific radionuclides are of concern in wastewater that will be generated from the processing of HLW in the F/H Tank Farms -. H-3, Co-60, Ru106, Sb-125, Cs-137, and Eu-154. Because of the low limits specified for these nuclides, they do not impact long-term performance or regulatory limits.

A limit has been established for tritium to minimize radiation hazards around the vaults during pouring and curing operations. Past waste handling practices in the Tank Farms (evaporation and aging of soluble waste) have reduced the level of tritium in existing soluble HLW stored in the $\mathrm{F} / \mathrm{H}$ Tank Farms to insignificant levels, compared to the limit of $1800 \mathrm{nCi} / \mathrm{g}(2.3 \mathrm{mCi} / \mathrm{L})$. The tritium limit is primarily specified to ensure wastewater sent to Z-Area from the F/H ETF does not introduce a radiological hazard in Z-Area, if water containing high levels of tritium are processed through the ETF. However, this limit also applies to feeds generated from the $F / H$ Tank Farm if waste streams containing high levels of tritium are sent to the tank farm in the future. (Hooker 1988)

Because of limited radiological shielding in the Saltstone Production Facility, wastewater must be treated to reduce the level of radioactive contaminants that emit high-energy gamma radiation. Based on extensive analysis of soluble waste samples, the principal gamma-emitting radionuclides in soluble HLW are Cs-137 and Ru-106. Other nuclides that have been observed in samples of soluble HLW waste that could coniribute to the total gamma dose to operating 
personnel are Co-60, Sb-125, and Eu-154. (Ondrejcin 1974; Fowler 1982a-c; Fowler, ot al 1984a,b. 1986) Specific limits and ALARA guides are provided for these isotopes in the Waste Acceptance Criteria (WAC), but all of them must be considered when the relative radiation hazard is calculated. Accordingly, a Radiation Control Guide (RCG) for these five gamma emitters has been developed that weights each nuclide as an equivalent radiological hazard. Using measured concentrations of these isotopes in the equation shown below, an RCG value can be calculated for wastewater to be transferred to Z-Area. Currently, concentrations are expressed in nCV/g when calculating the RCG value. Using concentrations expressed in $\mathrm{nCi} / \mathrm{ml}$ is also acceptable and would be conservative for salt solutions, since the density of the solution is greater than 1.

$$
\begin{aligned}
& R C G=0.145 \times[C 0.60]+0.0078 \times[R u-106]+0.013 \times[S b-125] \\
&+0.061[E u-154]+0.022 \times[C s-137]
\end{aligned}
$$

With respect to chemical contaminants, most anionic species have little impact on wastewater processing in Z-Area at the projected concentrations in ETF and Tank farm wastewater solutions. However, some of these species could affect either the treatment process in Z-Area or the saltstone product properties. For example, a significant increase in the concentrations of carbonate, sulfate, phosphate, fluoride, or oxalate could adversely alter the saltstone properties through reaction with the calcium component in the dry blend used to produce saltstone. Experimental results suggest that a significantly higher aluminate concentration may also increase the rates of hydration reactions during the production of saltstone, resulting in either rapid gelling that could prevent transfer to the vaults (flash setting) or excessive curing temperatures (>90 deg. C.) after the saltstone has been placed in the vault. Contaminants not specifically listed in the WAC, especially chelating agents, can not be introduced into Z-Area feeds without prior testing to establish limits of accoptability. ALARA guides for these species in the WAC reflect the laboratory and/or process experience with ranges of these species.

(Fowler 1992)

To assure that temperatures remain below $90 \mathrm{deg}$. C. during curing in the vault, the temperature of wastewater transferred to Z-area for treatment and disposal must be less than 40 deg. C. (Langton 1988b, Yu 1990, Fowler 1992) The pH of the wastewater must also be above 7 when it enters the Salt Solution Hold Tank in Z-Area, since this tank and other processing equipment in Z-Area is constructed of carbon steel.

\section{REGULATORY AND LONG-TERM PERFORMANCE LIMITS}

One condition of the Z-Area permits issued by SCDHEC requires that monthly saltstone samples be subjected to the Toxicity Characteristic Leach Procedure (TCLP) to show that saltstone is properly categorized as a non-hazardous, solid industrial waste. (SCDHEC 1986a-1988) To meet this requirement, limits for toxic metals are provided in the WAC. Leach rates of these species are mitigated by the slag formulation used in the production of saltstone. (Langton 1986a-1987d) Based on analyses of soluble HLW waste and process history for the separation areas, $\mathrm{Cr}$ (as chromate) and $\mathrm{Hg}$ are the only two hazardous metals that are present in significant concentrations, relative to limits and ALARA guides. Both of these species are projected to be well within the WAC acceptance limits in HLW waste and are usually below the ALARA guide values. (Fowler 1981, Walker and Fowler 1987)

The ITP process, through reaction with tetraphenylborate, removes $\mathrm{Hg}$ from the $\mathrm{HLW}$ wastewater. The levels of $\mathrm{Hg}$ in untreated $\mathrm{HLW}$ soluble waste are sufficiently low to preclude $\mathrm{Hg}$ removal. However, an increase in the $\mathrm{Hg}$ concentration in Z-Area feeds relative to the ITP effluent could be interpreted by SCDHEC as a significant change in the waste composition that

$$
--64-.
$$


would require significantly more monitoring or control. Technically, $\mathrm{Hg}$ removal is not required for HLW wastewater, but removal may be desirable to comply with the ALARA principal specified in DOE Order 5820.2A. A costbenefit analysis of $\mathrm{Hg}$ removal from soluble $\mathrm{HLW}$ may be desirable to establish if $\mathrm{Hg}$ removal is justified for wastewater generated from HLW soluble waste. (Lee and Kilpatrick 1982; Fowler 1981; Langton and Wilhite 1990)

A second regulatory condition of Z-Area permits specifies radionuclide limits promulgated by the NRC as the basis for disposal of Saltstone. Disposal of saltstone that exceeds Class $C$ limits as defined by the NRC cannot be placed in the Z-Area vaults. Furthermore. SCDHEC requires that the DOE report any quantity of waste that exceeds NRC Class $A$ limits. WSRC has adopted a long. term goal to maintain the overall average concentration of all saltstone sent to Z-Area vaults for disposal to be within the NRC Class A limits. This goal does not preclude disposal of some saltstone that exceeds NRC Class A limits, providing the average concentration in all the waste is below the Class $A$ limit. DOE Order $5820.2 A$ also specifies long-term pertormance goals for all LLW disposal sites, and this requirement limits the concentration of nuclides that are not normally considered to be significant radiological hazards. (SCDHEC 1986a-1988; USNRC 1982; USDOE 1988b)

Based on projected concentrations of radionuclides in the wastewater generated from soluble $\mathrm{HLW}$, nuclides of concern for either regulatory or long-term performance reasons are Se-79, Sr-90, Tc-99, Sn-126, 1-129, and total alpha activity (principally due to Pu-238, minor contributions from Pu-239, $U$ isotopes, and Np-237). Except for Sr-90, these species are of concern because of their long half-lives and their possible long-term impact on groundwater or an inadvertant intruder after administrative control is relinquished at the saltstone disposal site.

Sr-90 is included in this list because measured concentrations in HLW soluble waste samples exceeds the NRC Class A limit. However, none of the soluble HLW waste samples tested to date exceeds the NRC Class B limit for Sr-90. Furthermore, any Sr-90 in wastewater sent to ZArea would be incorporated into the insoluble solid matrix of saltstone, effectively eliminating Sr-90 from near-term environmental impact. The half-life of Sr-90 (29 years) is too low to be considered a long-term radiological hazard in saltstone. A costbenefit analysis of Sr-90 removal from soluble HLW may be desireble to establish if Sr removal is justified for wastewater generated from HLW soluble waste.

\section{ION EXCHANGE FEED CHARACTERISTICS}

\section{F-AREA AND H-AREA COMPOSITE SOLIDS}

The chemical and radiochemical composition of F-Area and $\mathrm{H}$-Area soluble waste (Table 2-3) was estimated to serve as a basis for the design of the DWPF and related in-tank processing. Methodology usedyo obtain the compositions are summarized in the references. For nuclides that little experimental data exists or that Waste Management Operations (WMO) does not maintain inventories on, a hypothetical production mix through Separations and an assumed split between soluble and insoluble fractions of the waste is used to estimate concentrations. (Fowler 1982C) The projected radionuclide content in soluble HLW is based an an assumed age of 15 years and a perfect blend of all salt solids. These estimates served as the design basis for the Z-Area process. The concentration of shorter-lived species (e.g. Co-60) shown in the table are higher than would be expected in older waste stored in the Tank Farms (average age >15 years).

WMO maintains inventory records on Cs-137, Ru-106, and Sr-90 in soluble and insoluble fractions of the waste. (Goslen 1988) These records were used to project the concentration of 
these 3 nuclides in the overall composite salt solution from the inventory. (Table 2.3) These estimates are conservative, since at least a portion of these nuclides are associated with insoluble solids that are a component of the soluble waste inventory.

To estimate the dissolved salt solution composition, an overall average density of 1.30 and 35 $w t \%$ soluble solids was assumed. These values approximate the salt solution properties observed during salt dissolution operations in Tanks 19F, 20F, and 24H. (Fowler 1982a-c) Based on the current waste inventory and these assumed solution properties, 70-75 million gallons of salt solution will be generated during dissolution operations that must be decontaminated before disposal in Z-Area.

\section{COMPOSITION OF FIRST TANKS TO BE PROCESSED}

Based on space limitations of the waste evaporator systems used in the F/H Waste Tank Farms, salt removal must be done in a specific sequence to enable the Tank Farms to gain salt storage space in evaporator systems critical to continuing operation of other SAS facilities. The projected removal sequence is Tank $41 \mathrm{H}$, Tank $25 \mathrm{~F}$. Tank $29 \mathrm{H}$, and Tank $28 \mathrm{~F}$ for the first four salt tanks. The salt in Tank $41 \mathrm{H}$ must be dissolved, decontaminated and sent to Z-Area before $S$. Area can begin radioactive operations. Otherwise, space will not be available in the Tank Farm for the recycle stream from S-Area. Salt must be removed from the other tanks to provide salt storage for the other waste evaporator systems. Otherwise, the evaporators will be unable to continue operation. Projected composition of the salt solutions from these four tanks are shown in Table 2-4. These compositions were estimated based on the history of waste types that were evaporated to fill these tanks. (Wilhite 1985)

\section{DWPF FEED ACCEPTANCE CRITERIA}

The feed acceptance criteria for DWPF as given in the draft DWPF Feed Acceptance Criteria do not significantly limit the ion exchange product stream. 1 in fact, the feed to DWPF from the proposed reference ion exchange process is very similar to the aqueous product from precipitate hydrolysis except there is no boron, lower alkali conient, and probably no volatile, flammable organics. With the possible exception of the amount of titanate, there should be no detrimental effect on the DWPF processes. Several criteria potentially relating to the ion exchange product are given below.

\section{Affected Criteria}

- Volatile, flammable organics

- Nitrite to precipitate hydrolysis

- Total nitrite/nitrate to melter

- Total Al, Fe, and alkali

- Cu solubility in glass

\section{Commenis}

Reviewed on a case by case basis. Cs/KTPB hydrolysis releases benzene. No flammabie organics are present from IX.

IX removes this criteria.

Limited by permitted NOx emissions. IX will send nitrite to saltstone instead of DWPF.

Affects glass liquidus. Less alkali going to DWPF because $\mathrm{K}$ not absorbed by resin.

Amount depends on glass redox. IX eliminates problem because no Cu catalyst needed for hydrolysis. 
IX Technology Assessment Report

WSRC-RP-92-1093

- 1 wt \% TiO2 in glass

Same amount of $\mathrm{THO}_{2}$ as for reference process.

Additional feed criteria not presently specified, but which are potentially affected by ion exchange are shown below.

\section{Affected Criteria}

- Ionic organics in precipitate

\section{Comments}

Affect hydrolysis catalyst activity. Not a problem with IX.

The ion exchange process can actually be decoupled from the DWPF if capacity for storage of the product is incorporated in the design. An appropriately sized hold tank for ion exchange product is all that is required to decouple. 


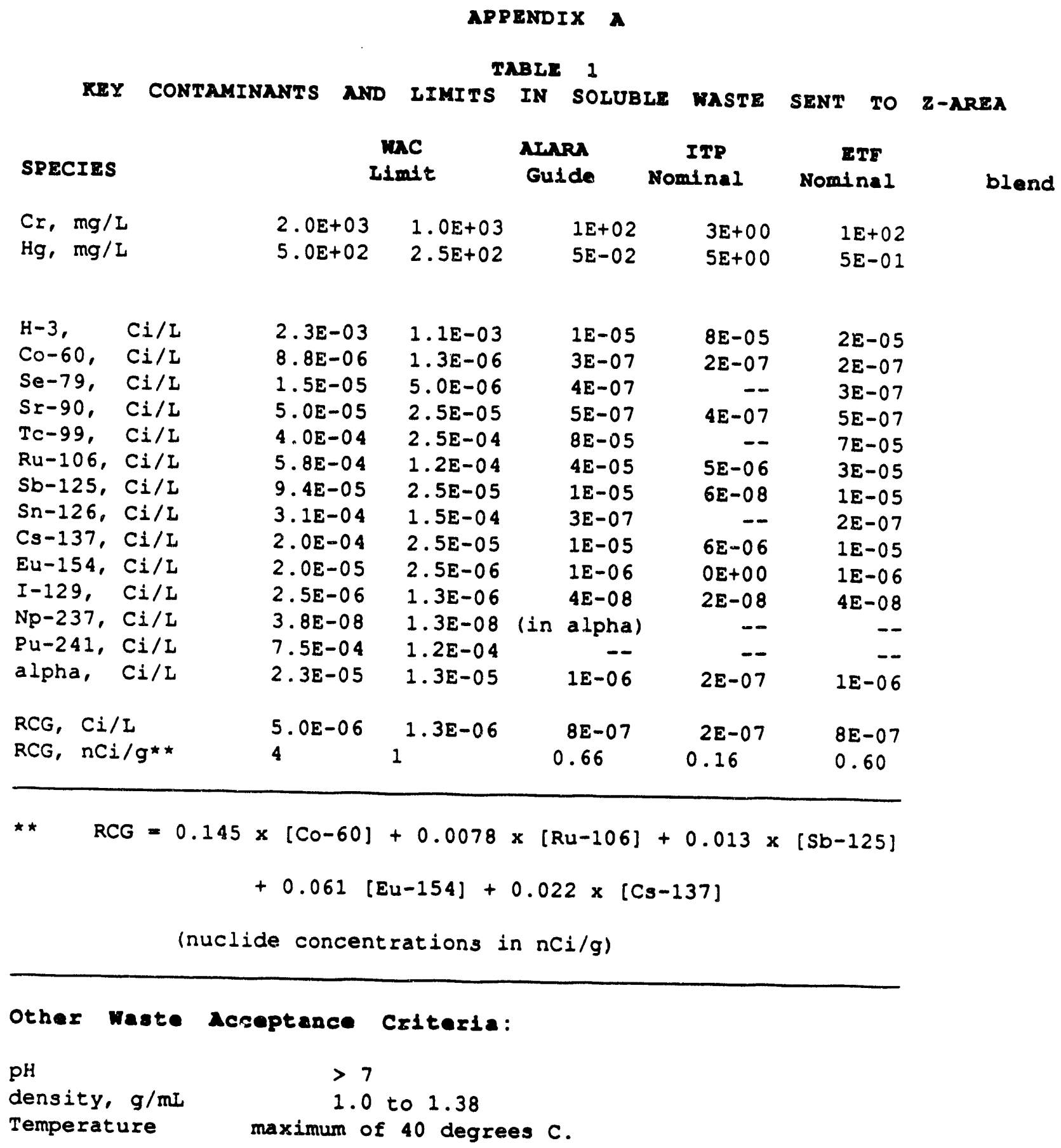




\section{Technology Assessment Report}

WSRC-RP-92-1093

\section{WASTE ACCEPTANCE CRITERIA MND AIARA GUIDES FOR Z-AREA FEED}

* Z-Area WAC specify $\mathrm{nCl} / \mathrm{g}$ for radionuclides, to comply with units used in regulations. Density of waste solution will vary, and acceptability is really dependent on the volumetric concentration, due to the nature of the SPF process. Accordingly, radionuclide limits are tabulated here on a volumetric basis. These volumetric limits assume a $28 \mathrm{wt} \%$ salt solution (sp.g. = 1.25) containing $350 \mathrm{~g} / \mathrm{L}$ of salt solids, to covert from $\mathrm{nCi} / \mathrm{g}$ to $\mathrm{Ci} / \mathrm{L}$.

\section{A. IIMITS SET BY REGULATORY/PERMIT REQUIREMENTS}

\section{SPECIES}

$\mathrm{As}, \mathrm{mg} / \mathrm{L}$
$\mathrm{Ba}, \mathrm{mg} / \mathrm{L}$
$\mathrm{Cd}, \mathrm{mg} / \mathrm{L}$
$\mathrm{Cr}, \mathrm{mg} / \mathrm{L}$
$\mathrm{Pb}, \mathrm{mg} / \mathrm{L}$
$\mathrm{Hg}, \mathrm{mg} / \mathrm{L}$
$\mathrm{Se}, \mathrm{mg} / \mathrm{L}$
$\mathrm{Ag}, \mathrm{mg} / \mathrm{L}$
$\mathrm{phenol}, \mathrm{mg} / \mathrm{L}$
$\mathrm{C}-14$,
$\mathrm{Ni}-59, \mathrm{Ci} / \mathrm{Ci}$
$\mathrm{Ni}-63, \mathrm{Ci}$
$\mathrm{Se}-79, \mathrm{Ci} / \mathrm{L}$
$\mathrm{Sr}-90, \mathrm{Ci} / \mathrm{L}$
$\mathrm{Nb}-94, \mathrm{Ci} / \mathrm{L}$
$\mathrm{I}-129, \mathrm{Ci} / \mathrm{L}$
$\mathrm{Np}-237, \mathrm{Ci} / \mathrm{L}$
$\mathrm{Pu}-241, \mathrm{Ci} / \mathrm{L}$
$\mathrm{alpha}, \mathrm{Ci} / \mathrm{L}$

inc

$1.0 E+03$

$1.0 E+03$

3. $0 E+02$

$2.0 E+03$

$1.0 E+03$

$5.0 \mathrm{E}+02$

$3.5 \mathrm{E}+02$

1. $0 E+03$

$1.0 E+03$

1. $0 E-03$

2. $9 E-02$

4. $6 \mathrm{E}-03$

1. 5E-05

$5.0 E-05$

2. 5E-05

2. $5 \mathrm{E}-06$

$3.8 \mathrm{E}-08$

$7.5 E-04$

2. 3E-05
IrARA

5. $0 E+02$

5. $0 E+02$

1. $5 E+02$

1. $0 E+03$

5. $0 E+02$

2. $5 E+02$

1. $8 \mathrm{E}+02$

5. $0 \mathrm{E}+02$

5. $O E+02$

\section{5. $0 E-04$}

6. $3 E-03$

1. $3 E-03$

5. $0 \mathrm{E}-06$

2. $5 E-05$

6. $3 E-06$

1. $3 \mathrm{E}-06$

1. $3 E-08$

1. $2 E-04$

1. $3 E-05$
ITP Nomina 1
ETE

Nominal

$\begin{array}{lrl}3 E-04 & -- & 3 E-04 \\ 2 E-04 & 3 E+00 & 3 E-01\end{array}$

$6 E-02 \quad 8 E+00 \quad 1 E-01$

$1 E+02 \quad 3 E+00 \quad 1 E+02$

$2 E-09 \quad 1 E+01 \quad 1 E+00$

5E-02 5E+00 5E-01

8E-01 -- 7E-01

9E-04

8E-04

$1 \mathrm{E}-08$

$3 E-10$

$3 E-08$

$4 E-07$

5E-07

$-$

$4 E-08$

(in alpha)

$1 E-06$

$$
\begin{array}{rr}
1 E-08 & 1 E-08 \\
-- & 2 E-10 \\
-- & 2 E-08 \\
-- & 3 E-07 \\
4 E-07 & 5 E-07 \\
-- & -- \\
2 E-08 & 4 E-08 \\
-- & -- \\
-- & -- \\
2 E-07 & 1 E-06
\end{array}
$$

\begin{tabular}{|c|c|c|c|c|c|}
\hline Benzene, $\mathrm{mg} / \mathrm{L}$ & $3.0 E+00$ & $2.0 E+00$ & -- & -- & -- \\
\hline Isopropanol, $\mathrm{mg} / \mathrm{L}$ & $2.0 E+03$ & $1.0 E+03$ & - & - & \\
\hline Methanol, $\mathrm{mg} / \mathrm{L}$ & $3.0 E+02$ & $1.5 E+02$ & -- & -- & \\
\hline $\mathrm{Ci} / \mathrm{L}$ & $2.3 E-03$ & $1.1 E-03$ & $1 E-05$ & $8 \Sigma-05$ & $2 \mathbf{E}-05$ \\
\hline Co-60, & $8.8 E-06$ & $1.3 E-06$ & $3 E-07$ & $2 E-07$ & $2 E-07$ \\
\hline Tc-99, & $4.0 E-04$ & $2.5 E-04$ & $8 E-05$ & -- & $7 E-05$ \\
\hline $\mathrm{Ru}-106, \mathrm{Ci} / \mathrm{L}$ & $5.8 E-04$ & $1.2 E-04$ & $4 E-05$ & $5 E-06$ & $3 E-05$ \\
\hline $\mathrm{Sb}-125, \mathrm{Ci} / \mathrm{L}$ & $9.4 \mathrm{E}-05$ & $2.5 E-05$ & $1 E-05$ & $6 E-08$ & $1 E-05$ \\
\hline $\mathrm{Sn}-126, \mathrm{Ci} / \mathrm{L}$ & $3.1 E-04$ & $1.5 E-04$ & $3 E-07$ & - & $2 E-07$ \\
\hline $\mathrm{Cs}-137, \mathrm{Ci} / \mathrm{L}$ & $2.0 E-04$ & $2.5 E-05$ & $1 E-05$ & $6 \Sigma-06$ & $1 E-05$ \\
\hline $\mathrm{Eu}-154, \mathrm{Ci} / \mathrm{L}$ & $2.0 E-05$ & $2.5 E-06$ & $1 E-06$ & $O E+O O$ & $1 E-06$ \\
\hline Beta-Gamma, Ci/L & $9.4 \mathrm{E}-03$ & $3.8 E-03$ & $-\infty$ & $1 E-05$ & $1 E-06$ \\
\hline RCG, $C i / I$ & $5.0 \mathrm{E}-06$ & $1.3 E-06$ & $8 E-07$ & $2 E-07$ & $8 E-07$ \\
\hline RCG, $n C i / g$ & 4 & 1 & 0.66 & 0.16 & 0.60 \\
\hline
\end{tabular}

\section{B. IIMITS SET BY SATETY/HAZARDS/IONG-TERY PERTORMNCE}


IX Technology Assessment Report

WS RC-RP-92-1093

TABLE 3

PROJECTED AVERAGE COMPOSITION OT SALT SOLUTIONS

WASTE TYPE $=$ F COMPOSITE

COMPONISNT.

$\mathrm{NaNO} 3$
$\mathrm{NaNO} 2$
$\mathrm{NaOH}$
$\mathrm{Na} 2 \mathrm{CO} 3$
$\mathrm{NaAl}(\mathrm{OH}) 4$
$\mathrm{Na} 2 \mathrm{SO} 4$
$\mathrm{NaF}$
$\mathrm{NaCl}$
$\mathrm{Na} 2 \mathrm{SiO} 3$
$\mathrm{Na} 2 \mathrm{CrO} 4$
$\mathrm{NaHgO}(\mathrm{OH})$
$\mathrm{Na} 2 \mathrm{MOO} 4$
$\mathrm{KNO} 3$
$\mathrm{Na} 2 \mathrm{C} 2 \mathrm{O} 4$
$\mathrm{CaSO} 4$
$\mathrm{Na} 3 \mathrm{PO} 4$
$\mathrm{NH} 4 \mathrm{NO} 3$

Assumed dens

1.30

450

2.6

7. $4 \mathrm{E}-01$

1.8

1. 3E-01

4. $0 E-01$

1. $8 E-01$

3. $6 \mathrm{E}-02$

3. $8 \mathrm{E}-02$

7. $0 \mathrm{E}-03$

3. $4 E-03$

$7.8 E-05$

4. $2 E-04$

2. $9 \mathrm{E}-02$

1. $4 \mathrm{E}-02$

3. $1 E-05$

1. $6 E-02$

1. $4 E-03$

h COmosite

\section{Molarity}

2.5

$8.5 E-01$

1. 2

3. 1E-01

4. 5E-01

2. $0 E-01$

3. $8 E-03$

1. $9 E-02$

5. 3E-03

5. 5E-03

2. $7 \mathbf{E}-04$

7. 2E-04

2. $4 \mathrm{E}-02$

7. $5 E-03$

2. $0 E-05$

7. 5E-03

1. $3 E-03$

1.30

450
OVERALI COMPOSITE

volarity

2.6

8. OE-02

1.5

2. $2 E-01$

4. $2 \mathrm{E}-01$

1. $9 \mathrm{E}-01$

2. $0 \mathrm{E}-02$

$2.8 \mathrm{E}-02$

$5.1 \mathrm{E}-03$

4. $4 E-03$

1. $8 E-04$

$5.7 \mathrm{E}-04$

2. $7 \mathrm{E}-02$

1. 1E-02

2. 5E-05

1. $2 \mathrm{E}-02$

1. 3E-03

\subsection{0}

450

$$
\begin{aligned}
& \mathrm{H}-3 \\
& \mathrm{Co}-60 \\
& \mathrm{Se}-79 \\
& \mathrm{~S} r-90 \\
& \mathrm{~T} c-99 \\
& \mathrm{Cs}-137 \\
& \mathrm{Ru}-106 \\
& \mathrm{~S} n-126 \\
& \mathrm{I}-129 \\
& \mathrm{Pu}-238 \\
& \mathrm{Pu}-239
\end{aligned}
$$
$1 E-05$
$4 E-07$
$6 E-07$
$3 E-02$
$2 E-05$
2
$4 E-04$
$3 e-07$
$3 E-08$
$8 E-06$
$8 E-08$ 
IX Technology Assessment Report

WSRC-RP-92-1093

TABIE 4

PROJECTED COMPOSITION OE SOLUTIONS FROM INITIAI TANKS TO BE PROCESSED

\begin{tabular}{|c|c|c|c|c|c|}
\hline TANK $=$ & $41 \mathrm{H} / 38 \mathrm{H}$ & $25 F$ & $29 \mathrm{H} / \mathrm{BOT} 31 \mathrm{H}$ & TOP $31 \mathrm{H}$ & $28 \mathrm{~F}$ \\
\hline WASTE TYPE & HM LHW & E COMP & H COMP & PX/HM HHW & $19 / 20$ blen \\
\hline COMPONENT & & & & & \\
\hline & Molarity & Melarity & Melarity & Molarity & Melarity \\
\hline NaNO3 & $3.1 E+00$ & $2.6 \mathrm{E}+00$ & $2.5 E+00$ & $2.9 E+00$ & $3.7 E+00$ \\
\hline $\mathrm{NaNO} 2$ & $6.9 E-01$ & $7.4 \mathrm{E}-01$ & $8.5 E-01$ & $1.1 E+00$ & $7.2 \mathrm{E}-02$ \\
\hline $\mathrm{NaOH}$ & $1.5 E+00$ & $1.8 E+00$ & $1.2 E+00$ & $7.2 \mathrm{E}-01$ & $8.1 E-01$ \\
\hline $\mathrm{Na} 2 \mathrm{CO} 3$ & $6.8 E-02$ & 1. $3 E-01$ & 3. $1 E-01$ & $2.0 E-01$ & $9.4 E-02$ \\
\hline $\operatorname{NaAl}(\mathrm{OH}) 4$ & $4.1 E-01$ & $4.0 E-01$ & 4. $5 E-01$ & $4.5 E-01$ & $2.1 E-01$ \\
\hline $\mathrm{Na} 2 \mathrm{SO}_{4}$ & $6.8 E-02$ & $1.8 E-01$ & 2. OE-OI & $1.1 \mathrm{E}-01$ & $3.0 E-01$ \\
\hline $\mathrm{NaF}$ & $9.7 E-03$ & $3.6 \mathrm{E}-02$ & $3.8 E-03$ & $2.8 E-03$ & $3.2 E-02$ \\
\hline $\mathrm{NaCl}$ & $1.1 E-02$ & $3.8 E-02$ & 1. $9 E-02$ & 1. $6 \mathrm{E}-02$ & 1. $4 E-02$ \\
\hline $\mathrm{Na} 2 \mathrm{SiO} 3$ & $7.1 E-03$ & $7.0 \mathrm{E}-03$ & 5. $3 E-03$ & 1. $6 \mathrm{E}-02$ & $2.7 E-03$ \\
\hline $\mathrm{Na} 2 \mathrm{CrO} 4$ & $2.3 E-03$ & $3.4 E-03$ & $5.5 E-03$ & $2.6 \mathrm{E}-03$ & $2.1 E-04$ \\
\hline $\mathrm{NaHgO}(\mathrm{OH})$ & $3.9 E-04$ & $7.8 E-05$ & $2.7 E-04$ & $7.2 \mathrm{E}-04$ & $6.3 E-08$ \\
\hline $\mathrm{Na} 2 \mathrm{MOO} 4$ & $0.0 E+00$ & $4.2 E-04$ & $7.2 E-04$ & 2.1E-03 & $3.6 E-05$ \\
\hline KNO3 & $4.5 E-02$ & 2. $9 E-02$ & 2. $4 E-02$ & $6.4 \mathrm{E}-03$ & $1.1 E-02$ \\
\hline $\mathrm{Na} 2 \mathrm{C} 204$ & $5.7 E-03$ & $1.4 \mathrm{E}-02$ & $7.5 E-03$ & $5.2 E-03$ & $4.0 E-03$ \\
\hline CaSO 4 & $0.0 E+00$ & $3.1 E-05$ & $2.0 E-05$ & $0.0 \mathrm{E}+00$ & $3.5 E-05$ \\
\hline $\mathrm{Na} 3 \mathrm{PO}_{4}$ & $4.7 E-03$ & $1.6 \mathrm{E}-02$ & $7.5 E-03$ & $1.8 \mathrm{E}-02$ & 4.1E-05 \\
\hline $\mathrm{NH} 4 \mathrm{NO} 3$ & 4. 3E-03 & $1.4 \mathrm{E}-03$ & 1. $3 E-03$ & 2. $3 E-05$ & $0.0 \mathrm{E}+00$ \\
\hline Assumed density & 1.30 & 1.30 & 1.30 & 1.30 & 1.30 \\
\hline g sajt/L & 450 & 450 & 450 & 450 & 450 \\
\hline SOIUBLE & Es, & 1ter: & & & \\
\hline $\mathrm{Cs}-137$ & $9.8 \mathrm{E}-02$ & $2.8 E-01$ & 1. $4 \mathrm{E}+00$ & 1. $1 E+00$ & $2.1 E-02$ \\
\hline$S r-90$ & $3.9 E-03$ & $4.6 E-03$ & $3.0 E-02$ & $3.0 E-02$ & $8.5 E-04$ \\
\hline $\mathrm{Pu}-238,239$ & & & & & $1.5 E-06$ \\
\hline TC-99 & $4.0 E-05$ & $3.0 E-05$ & $4.0 E-04$ & $3.0 E-04$ & $2.0 E-05$ \\
\hline$R u-106$ & $3.0 E-07$ & $3.0 \mathrm{E}-07$ & $2.0 E-06$ & $2.4 E-06$ & 5.0E-07 \\
\hline $\mathrm{Se}-79$ & & & & & $1.0 E-06$ \\
\hline $\mathrm{Co}-60$ & & & & & $1.0 E-05$ \\
\hline
\end{tabular}




\section{APPENDIX B \\ CONCEPTUAL FLOW DIAGRAMS \& FLOWSHEETS}

\section{Purpese}

The purpose of this section is to provide a comparison of possible process alternatives based on equivalent operating conditions, bases, and assumptions. Alternatives were chosen for comparison based on the initial evaluation of ion exchange media and application to waste removal and the DWPF. The simplified flowsheets are designed to elucidate principal differences among the alternatives and to judge integration with and impact on the DWPF.

\section{General Description}

Each process alternative is required to

- handle the sludge particulates in the salt solution

- sufficiently remove Sr and Pu to meet saltstone requirements

- remove $\mathrm{Hg}$ to meet salistone requirements and/or protect the TP.207 column

- remove Cs to meet saltstone requirements

- provide a feed which is not obviously incompatible with the DWPF

Three basic cases were chosen for conceptual flowsheeting:

- Organic resin with spent resin fed to the DWPF, both once-through and with regeneration by elution

- Zeolite with spent exchanger fed to the DWPF; evaluated at two temperatures because of significant improvement of $\mathrm{Kd}$ at reduced temperature

- Organic resin with regeneration by elution and low level waste disposal of the spent resin

In addition, one case (once-through) is evaluated with a TP-207 column. The summary of cases is

Case 1A Organic resin (to DWPF) - once-through

Case 1B Organic resin (to DWPF) - once-through with TP-207 (max carbon to melter)

Case 2A Organic resin (to DWPF) - elution with formic acid

Case 28 Organic resin (to DWPF) - elution with nitric acid

Case 3A Zeolite (to DWPF) @ $40^{\circ} \mathrm{C}$

Case 38 Zeolite (to DWPF) @ $10^{\circ} \mathrm{C}$

Case 4 Organic resin (to LLW) - elution with formic acid

Block diagrams with stream descriptions and numbers are shown along with the flowsheets on pages B6 through B17.

\section{Bases \& Asaumptions for Flowsheats}

1) Primary and reference feed streams are taken from latest DWPF CPES balance ${ }^{1}$. "late wash" flowsheet with formic acid to the SRAT. This is done in order to provide a base 
case comparison and to assure appropriately ratioed ion exchange streams to DWPF streams.

Primary feed streams

- salt workoff is the same as stream 401 except sufficient water is added to dilute to 5.5 $\mathrm{MNa}$

- $401 \mathrm{~b}$ is NaTi2O5H (only) per CPES stream 404

Reference streams

- Sludge feed per CPES stream 1

- Decontaminated salt solution to 2 Area per CPES stream 407

- Precipitate feed per CPES stream 201

- Water added to SPC is difference between water in stream 201 and stream 247

- Formic acid is sum of CPES streams 206 and 8

- Frit is frit portion of CPES streams $26 \& 27$

2) Filter flush water (stream 2a)

- water for $\sim 20 \%$ slurry of sludge $+\mathrm{NaTi} 2 \mathrm{O} 5 \mathrm{H}$ solids

3) Ion exchange column cycles - cycle descriptions and stream destinations are adapted from a memo by J. R. Fowler. ${ }^{2}$ The volume requirements (fill, flush, condition, rinse, etc) are adapted from a memo by J. P. Bibler. ${ }^{3}$ The quantities of water specified in reference 3 are very liberal and result in conservative estimates of rinse, flush, condition, and fill quantities. Significant reductions are likely to be achievable, but would not change the conclusions of the flowsheet comparisons.

3a) in order to minimize additional flows of essentially clean water to either saltstone or DWPF, it is assumed that water used to slurry resin into the columns is recycled, cleaned up and sent to ETF, used for sludge processing, or otherwise disposed of

3b) SRS resin

$200 \mathrm{gal}$ colurnn @ $3.0 \mathrm{lbs}$ resin/gal of bed volume $\Rightarrow 600 \mathrm{lbs}$ resin/column

Once through: $\quad 200 \mathrm{cbv} / \mathrm{cycle} \Rightarrow 40,000 \mathrm{gal}$ salt solution/cycle resin used $=600 \mathrm{lbs} / 40,000 \mathrm{gal}=0.015 \mathrm{lbs} / \mathrm{gal}$ salt $\mathrm{soln}^{4}$ (ss) cycle time $1095 \mathrm{gal} \mathrm{ss} / \mathrm{hr}=\frac{40000 \mathrm{gal}}{1095 \mathrm{gal} / \mathrm{hr}} \sim 36$ hours

$\begin{array}{lccl}\text { Step } & \text { cby } & \text { gal/aal ss } & \text { Destination } \\ \text { slurry resin into column } & 20 & 0.100 & n / a \\ \text { condition w/ 2M NaOH } & 5 & 0.025 & \text { decon salt soln } \\ \text { process salt soln } & 200 & & \text { decon salt soln } \\ \text { wash w/ 2M NaOH } & 5 & 0.025 & \text { salt feed makeup } \\ \text { water rinse } & 5 & 0.025 & \text { salt feed makeup } \\ \text { slurry resin out } & 25 & 0.125 & \text { DWPF feed tank }\end{array}$

With elution: total of 6 cycles (5 elution cycles) 5

$1200 \mathrm{cbv} / \mathrm{cycle} \Rightarrow 240,000 \mathrm{gal}$ salt solution/cycle

resin used $=600 \mathrm{lbs} / 240,000 \mathrm{gal}=0.0025 \mathrm{lbs} / \mathrm{gal}$ salt soln (ss)

cycle time $=\frac{240000 \mathrm{gal}}{1095 \mathrm{gal} / \mathrm{hr}} \sim 219$ hours 


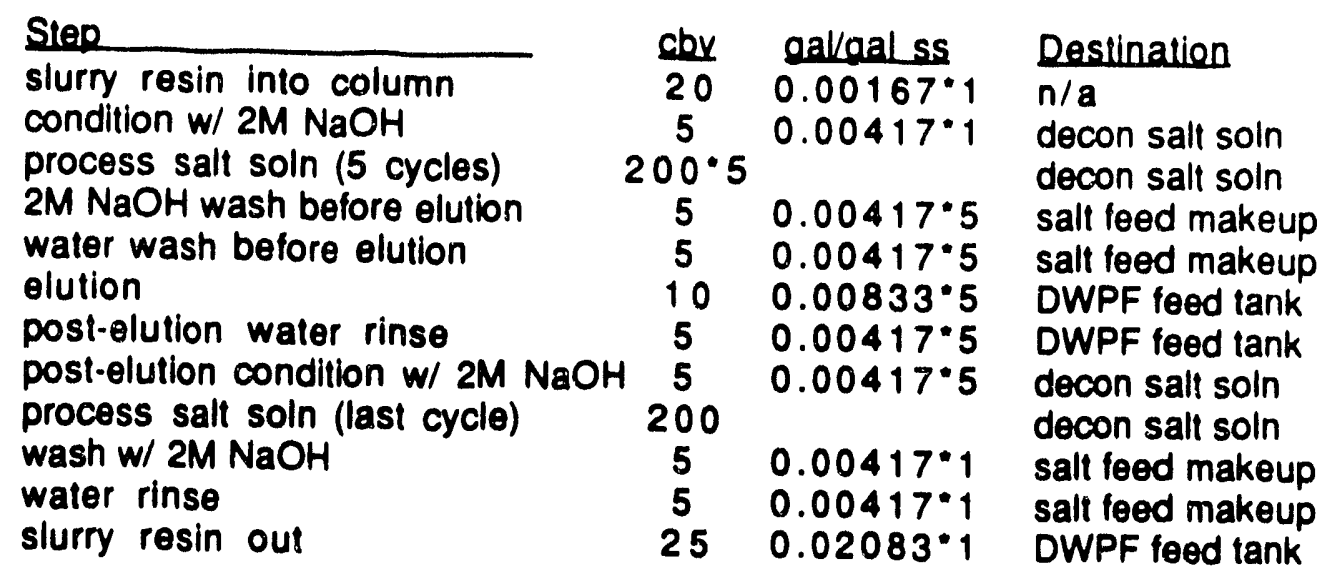

Elution with secondary disposal of resin:

total of 6 cycles

$1200 \mathrm{cbv} /$ cycle $\rightarrow 240,000 \mathrm{gal}$ salt solution/cycle

resin used $=600 \mathrm{lbs} / 240,000 \mathrm{gal}=0.0025 \mathrm{lbs} / \mathrm{gal}$ salt soln (ss)

cycle time $=\frac{240000 \mathrm{gal}}{1095 \mathrm{gal} / \mathrm{hr}}-219$ hours

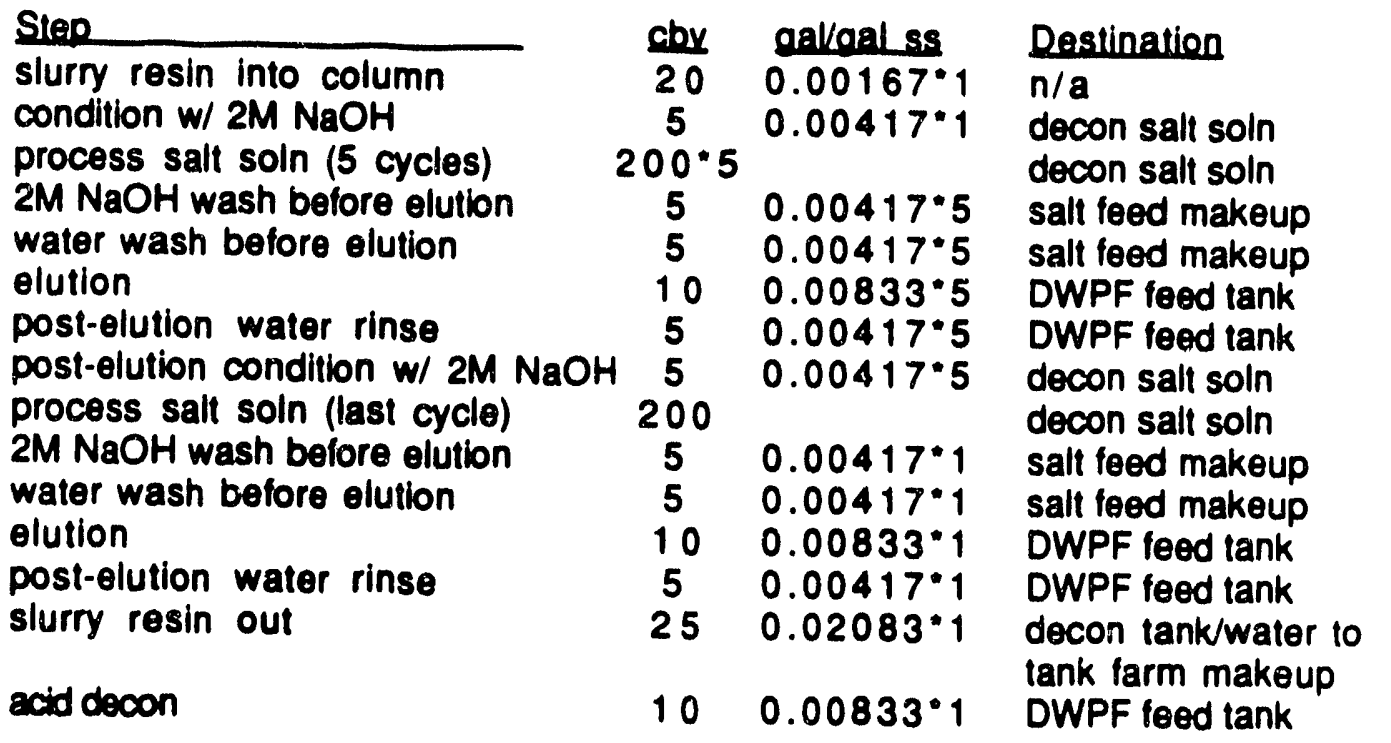

3C) Zeolite (IE-95)

Iemo $=40^{\circ} \mathrm{C}$

consumption per JPB (from Bray's data) is 0.25 lbs zeolite/gal sall soln 6

$200 \mathrm{gal}$ column $96.0 \mathrm{lbs}$ resin/gal of bed volume $\Rightarrow 1200 \mathrm{lbs}$ resin/column 1200 lbs zeolite

0.25 lbs zeolite/gal salt soln $=4800 \mathrm{gal}$ ss $\Rightarrow 24 \mathrm{cbv} / \mathrm{cycle}$

cycle time $=\frac{4800 \mathrm{gal}}{1095 \mathrm{gal} / \mathrm{hr}}-4.4$ hours (these columns would be much largerll)

Siep cby gakaalss Destination 


$\begin{array}{llll}\text { slurry resin into column } & 20 & 0.83333 & \mathrm{n} / \mathrm{a} \\ \text { process salt soln } & 24 & & \begin{array}{l}\text { decon salt soln } \\ \text { Dlurry resin out }\end{array} \\ \text { DWPF feed tank }\end{array}$

Iemp $=10^{\circ} \mathrm{C}$

consumption per JPB (from Bray's data) is 0.0893 lbs zeolite/gal salt soln 6 $200 \mathrm{gal}$ column @ $6.0 \mathrm{lbs}$ resin/gal of bed volume $\Rightarrow 1200 \mathrm{lbs}$ resin/column $\frac{1200 \mathrm{lbs} z e 0 l i t e}{0.0893 \mathrm{lbs} z e 0 \text { ite/gal salt soln }}=13440 \mathrm{gal} \mathrm{ss} \Rightarrow 67.2 \mathrm{cbv} / \mathrm{cycl} \theta$ cycle time $=\frac{13440 \mathrm{gal}}{1095 \mathrm{gal} / \mathrm{hr}} \sim 12.3$ hours

3d) $\mathrm{Hg}$ resin (GT-73)

$200 \mathrm{gal}$ column @ $4.8 \mathrm{lbs}$ resin/gal of bed volume $\Rightarrow 960 \mathrm{lbs}$ resin/column $1450 \mathrm{cbv} / \mathrm{cycle} \Rightarrow 290,000 \mathrm{gal}$ salt solution/cycle resin used $=960 \mathrm{lbs} / 290,000 \mathrm{gal}=0.00331 \mathrm{lbs} / \mathrm{gal}$ salt soln 7 cycle time $=\frac{290000 \mathrm{gal}}{1095 \mathrm{gal} / \mathrm{hr}} \sim 265$ hours

Step slurry resin into column condition w/ $2 \mathrm{M} \mathrm{NaOH}$ process salt soln wash w/ $2 \mathrm{M} \mathrm{NaNO}{ }_{3}$ water rinse slurry resin out assumes $80 \%$ reuse

$\begin{array}{ccl}\text { cbv } & \text { gal/aal ss } & \text { Destination } \\ 20 & 0.01379 & \mathrm{n} / \mathrm{a} \\ 5 & 0.00345 & \begin{array}{l}\text { decon salt soln } \\ \text { decon salt soln }\end{array} \\ 1450 & & \text { salt feed makeup } \\ 5 & 0.00345 & \text { salt feed makeup } \\ 5 & 0.00345 & \text { Hg resin storage }\end{array}$

3e) Sr resin (TP.207) 200 gal column @ 3.9 lbs resin/gal of bed volume $\Rightarrow 780$ lbs resin/column $610 \mathrm{cbv} /$ cycle $\Rightarrow 122,000 \mathrm{gal}$ salt solution/cycle resin used $=780 \mathrm{lbs} / 122,000 \mathrm{gal}=0.00639 \mathrm{lbs} / \mathrm{gal}$ salt soln 8 cycle time $=\frac{120000 \mathrm{gal}}{1095 \mathrm{gal} / \mathrm{hr}} \sim 111$ hours

$\begin{array}{lcccl}\text { Step } & & \text { cby } & \text { gal/aal ss } & \text { Destination } \\ \text { slury resin into column } & 20 & 0.03280 & \\ \text { condition } w / 2 \mathrm{M} N \mathrm{NaOH} & & 5 & 0.00820 & \text { decon salt soln } \\ \text { process salt soln } & 610 & & \text { decon salt soln } \\ \text { slurry resin out } & 25 & 0.04098 & \text { DWPF feed tank }\end{array}$

4) Sg of various streams used in column cycles - $2 \mathrm{M} \mathrm{NaOH}, \mathrm{Sg}$ assumed to be $1.1 \Rightarrow$ - $2 \mathrm{M} \mathrm{NaNO}$, $\mathrm{Sg}$ assumed to be $1.1 \Rightarrow$ $-1 \mathrm{M} \mathrm{HCOOH}, \mathrm{Sg}$ assumed to be $1.05 \Rightarrow$ $7.3 \% w t \mathrm{NaOH} \& \quad \rho=9.17 \mathrm{lbs} / \mathrm{gal}$ - $0.1 \mathrm{M} \mathrm{HNO}_{3}, \mathrm{Sg}$ assumed to be 1.01 $15.1 \%$ w $\mathrm{NaNO}_{3}$ $4.4 \%$ w NaOH $\& \quad \rho=9.17 \mathrm{lbs} / \mathrm{gal}$ \& $\rho=8.76 \mathrm{lbs} / \mathrm{gal}$ $0.62 \% w t \mathrm{HNO}_{3} \& \quad \&=8.42 \mathrm{lbs} / \mathrm{gal}$

5) Zeolite process

- $\mathrm{pH}$ adjustment to 9.0: add sufficient $\mathrm{HNO}_{3}$ to react $\mathrm{KOH}, \mathrm{NaOH}$ and $\mathrm{NaAl}(\mathrm{OH})_{4} \rightarrow \mathrm{Al}(\mathrm{OH})_{3}$

- $\mathrm{HNO}_{3}$ is $80 / 20$ mixture of $50 \%$ and $10 \% \mathrm{HNO}_{3}$ 
- pH adjustment to 9.5: $\mathrm{NaOH}$ added per JPB's experiment

- 2nd filter: $\mathrm{Hg}$ and $\mathrm{Al}(\mathrm{OH})_{3}$ are filtered out; add sufficient $\mathrm{NaOH}$ to redissolve $\mathrm{Al}(\mathrm{OH})_{3}$ $+10 \%$; washing prior to dissolution would probably be required but is not included

- water removal step required for DWPF compatibility; $90 \%$ removal is assumed

- glass formulation per CMJantzen

\section{Summary of results}

The flowsheets for each case are shown on pages B6 through B17. Each flowsheet also includes a block at the bottom summarizing the impact on the DWPF as compared to the reference flowsheet. The results of the cases are summarized as follows:

\begin{tabular}{|c|c|c|c|c|c|c|c|c|}
\hline \multirow{3}{*}{\multicolumn{2}{|c|}{ All flows in lbs/hr }} & \multicolumn{5}{|c|}{ Oroanic (SRS) Reein } & \multirow{2}{*}{\multicolumn{2}{|c|}{ Zeolite }} \\
\hline & & \multicolumn{2}{|c|}{ Once Through } & \multicolumn{3}{|c|}{ With Add ElutionWith elution a } & & \\
\hline & & $w / 0$ TP.207 & $w$ TP.207 & Eormic & Nitrie & resin disposal & $I=40^{\circ} \mathrm{C}$ & $I=10^{\circ} \mathrm{C}$ \\
\hline & Beterence & CASE 10 & CASE 18 & CASE2A & CASE2B & CASE 4 & CASE 3A & CASE 3B \\
\hline Decon salt soln & 14840 & 12407 & 12481 & 12405 & 12405 & 12406 & 17287 & 17297 \\
\hline Water to SPC & 922 & 1157 & 1531 & 778 & 777 & 778 & 967 & 1034 \\
\hline HCOOH to SPC & 21.4 & $\ldots$ & .................. & 17.6 & .............................. & 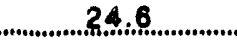 & $\ldots$ & $\ldots$ \\
\hline HNOB & 0 & 0 & 0 & 0 & 2.4 & 0 & 0 & 0 \\
\hline Organic rosin & 0 & 16.4 & 23.4 & 2.7 & 2.7 & 0 & 0 & 0 \\
\hline Zeolite & 0 & 0 & 0 & $\ldots$ & 0 & 0 & 274 & 98 \\
\hline Frit & 152 & 160 & 160 & 160 & 160 & 160 & 100 & 120 \\
\hline Glass & 228 & 228 & 228 & 228 & 228 & 228 & 393 & 267 \\
\hline
\end{tabular}

The significant differences/observations are:

- In all cases except for zeolite, salt solution to saltstone is decreased by about $15 \%$ (approximately $4 \mathrm{gal} / \mathrm{min}$.).

- In the case of zeolite, salt solution to saltstone is increased by about $15 \%$ (approximately $4 \mathrm{gal} / \mathrm{min}$ ) because the acid neutralization and caustic redissolution steps.

- In the case of once-through, water to the Salt Process Cell (SPC) increases somewhat (about 25-50\%) while it is decreased in the elution cases. The zeolite process requires a water removal step to prevent a severe water impact on DWPF.

- For the formic acid elution cases, the amount of acid utilized is comparable to that already added to the SPC for the reference flowsheet.

- The once-through processes show a significantly large carbon load to the melter; this leads to issues related to melter redox balance and deposition of noble metals in the melter. However, this problem should be somewhat offset by the reduction in formic acid/formate in the melter feed. 
- For the case of acid elution with secondary disposal of the resin, the non-volatile carbon load on the melter is approximately the same as in the reference DWPF flowsheot.

- In both zeolite cases (at $40^{\circ} \mathrm{C}$ and $10^{\circ} \mathrm{C}$ ), the high quantities of zeolite being fed cause glass production to increase significantly - $73 \%$ and $17 \%$, respectively. In reality, DWPF throughput (and salt solution workoff) would be decreased to produce the nominal $228 \mathrm{lbs} / \mathrm{hr}$ glass. The number of canisters to process a given quantity of waste would be increased by the same percentages.

- In both zeolite cases, the glass formulation for "average" sludge was near one of the melter limits (i.e., liquidus, viscosity). In Case 3A, high aluminum sludge could be very difficult to process, while high iron sludge would present problems in Case 3B.

\section{Beferences:}

1. ChOi, A. S., PRELIMINARY MATERIAL BALANCE TABLES FOR THE OWPF FINAL WASH FLOWSHEET, WSRC-TR-92-211, Rev. 1, August, 1992.

2. Fowler, J. R., PRELIMINARY BASES FOR ION EXCHANGE PROCESSING TO DECONTAMINATE HIGH ACTIVITY SOLUBLE WASTE, WSRC-RP-90-1123, September, 1990.

3. Bibler, J. P., ION EXCHANGE AT TNX, SRT-IWT-92-082, June, 1992, draft.

4. Wallace, R. M., and Bibler, J. P., AN IMPROVED METHOD FOR DECONTAMINATING SOLUBLE HIGH-LEVEL WASTE USING ION EXCHANGE, DPST-88-789, August, 1988.

5. Bray, L. A., Elovich, R. J., and Carson, K. J., CESIUM RECOVERY USING SAVANNAH RIVER LABORATORY RESORCINOL-FORMALDEHYDE ION EXCHANGE RESIN, PNL-7273/UC-510, March, 1990.

6. Bray, L. A., Carson, K. J., Elovich, R. J., and Kurath, D.E., BATCH DISTRIEUTION DATA FOR CC AND NCAW WASTES AS A FUNCTION OF THE Na/Cs MOLE RATIO, TEMPERATURE, AND Na+ CONCENTRATION, August, 1992 (as yet unpublished)

7. Bibler, J. P., and Wallace, R. M., MERCURY REMOVAL FROM SUPERNATE USING ION EXCHANGE, DPST-84-848, October, 1984.

8. Walker, D. D., and Wallace, R. M., TECHNICAL DATA SUMMARY FOR ION EXCHANGE REMOVAL OF STRONTIUM, memorandum to L. F. Landon, October, 1988. 


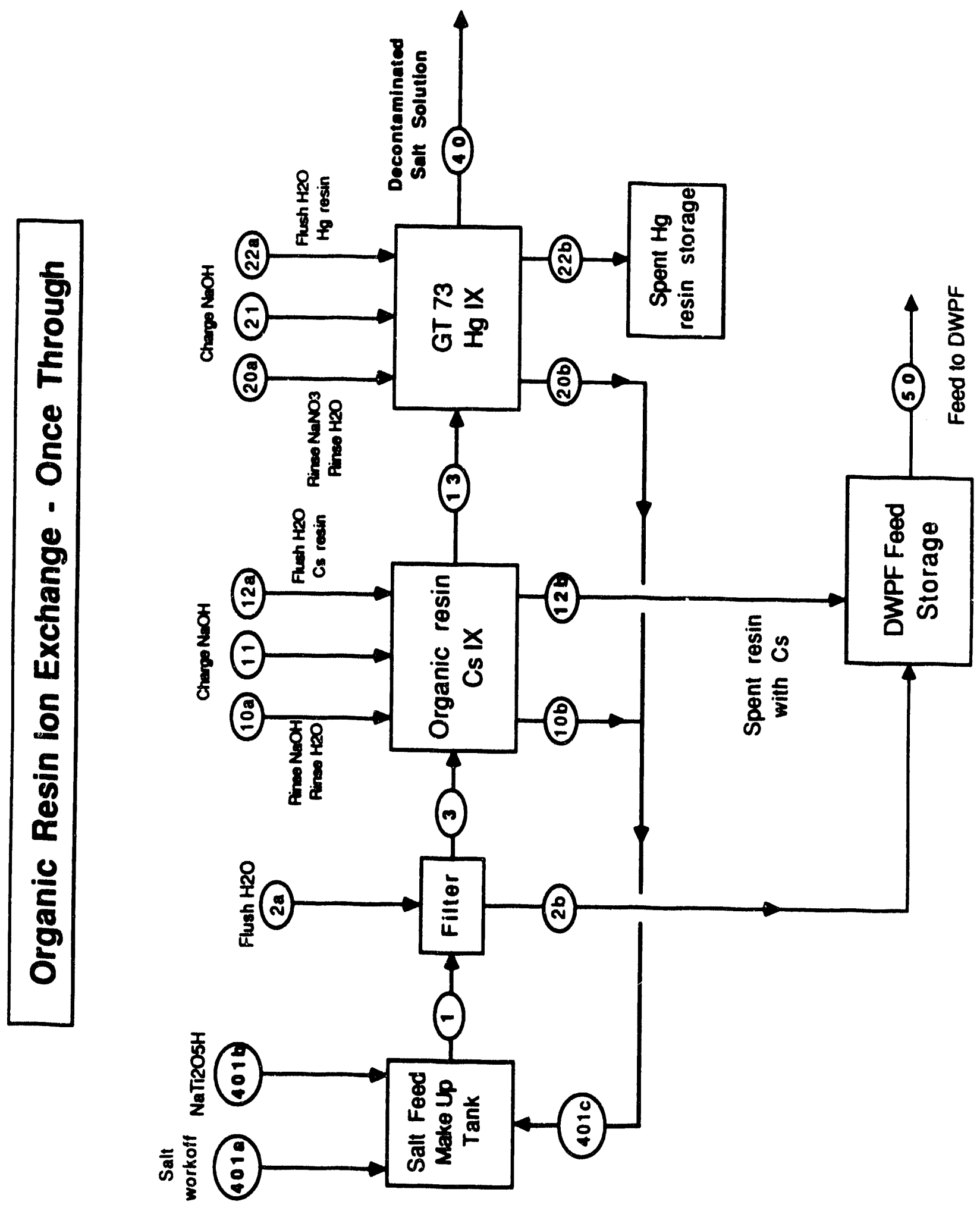




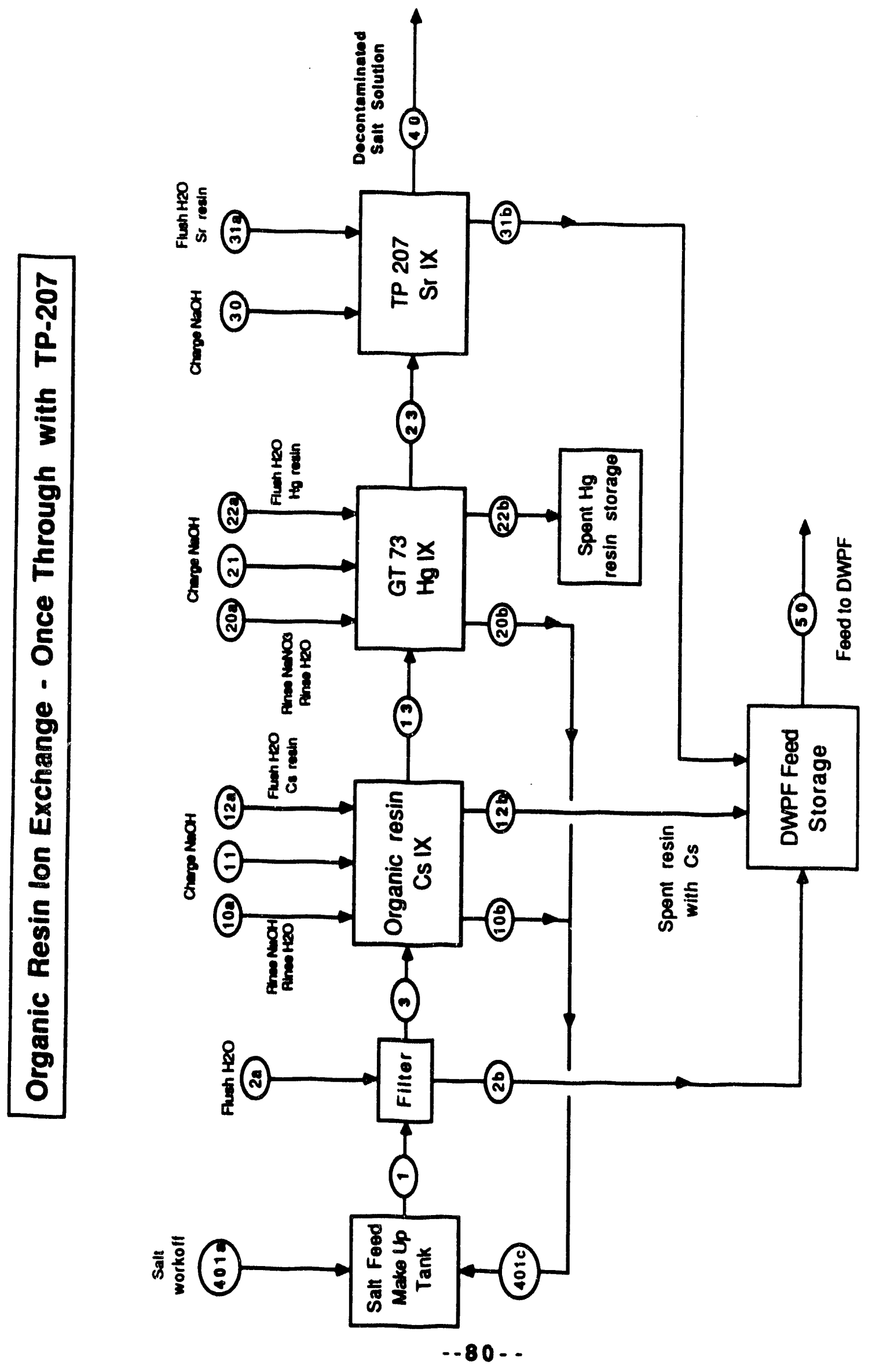




\section{Tochnology Assessment Report}

WSRC-RP-92-1093

CASE 18 ORGanic Resin ION EXChange - ONCE THROUgh WITH TPZOT (SAS RESIN)

\begin{tabular}{|c|c|c|c|c|c|c|c|c|c|c|c|}
\hline $\begin{array}{l}\text { Flows are in } 16 \mathrm{~h} / \mathrm{h} \\
\text { Description }\end{array}$ & $\begin{array}{c}\text { Sel Maka } \\
\text { Sal } \\
\text { Workoff }\end{array}$ & $\begin{array}{l}\text { Up Tank } \\
\text { Resrele }\end{array}$ & $\begin{array}{l}\text { Ion Excho } \\
\text { Process } \\
\text { Find }\end{array}$ & $\begin{array}{l}\text { Filter } \\
\text { Flush } \\
\text { Water }\end{array}$ & $\begin{array}{l}\text { Filter } \\
\text { Flueh }\end{array}$ & $\begin{array}{l}\text { Fillored } \\
\text { Fend b } \\
\text { CeIX }\end{array}$ & $\begin{array}{c}\text { Colx } \\
\text { Rines } \\
\text { Sireams }\end{array}$ & $\begin{array}{l}\text { Cex } x \\
\text { Rines } \\
\text { Regrele }\end{array}$ & $\begin{array}{l}\text { Cox } \\
\text { Chapo } \\
\text { Nor }\end{array}$ & 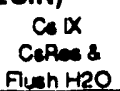 & $\begin{array}{l}\text { Colx } \\
\text { Spent } \\
\text { Cenes }\end{array}$ \\
\hline Stream Numbor & 4011 & $401 \mathrm{c}$ & 1 & 20 & $2 b$ & 3 & 102 & 100 & 11 & $12 a$ & $12 b$ \\
\hline
\end{tabular}

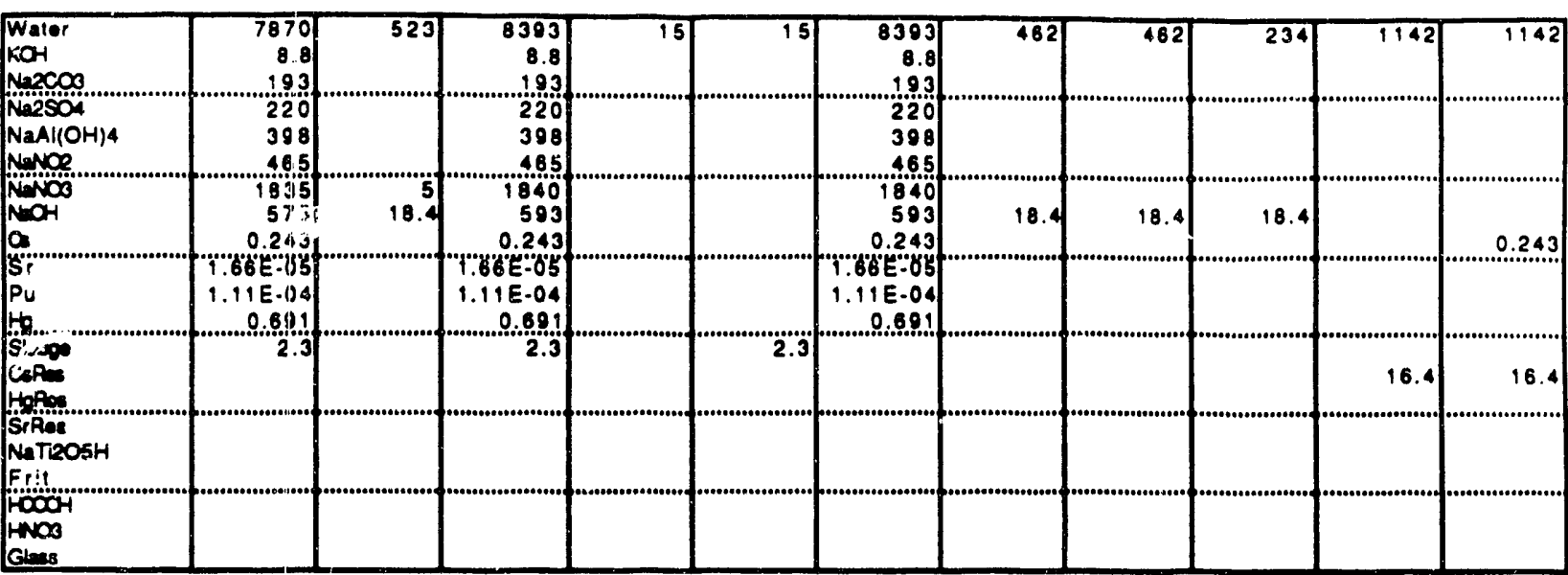

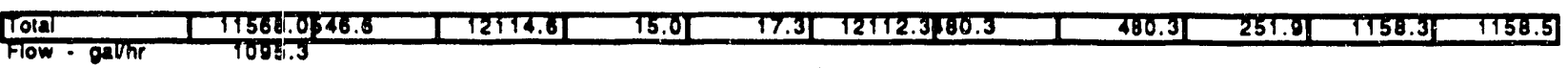

\begin{tabular}{|c|c|c|c|c|c|c|c|c|c|c|c|c|}
\hline & $\begin{array}{l}\text { Fond } x) \\
\text { Hod }(x)\end{array}$ & 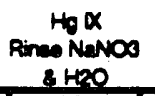 & $\begin{array}{l}\text { Hox } x \\
\text { Rines } \\
\text { Rogelo }\end{array}$ & $\begin{array}{l}\text { ho } 1 x \\
\text { cheope } \\
\text { Nog }\end{array}$ & 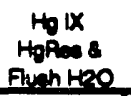 & $\begin{array}{l}\text { Holx } \\
\text { Spont } \\
\text { Hofin }\end{array}$ & $\begin{array}{l}\text { Foed bo } \\
\text { St IX }\end{array}$ & $\begin{array}{l}\text { Si IX } \\
\text { Charge } \\
\text { Nog }\end{array}$ & $\begin{array}{c}\text { Sr IX } \\
\text { SiRes } \\
\text { Fish H?O }\end{array}$ & $\begin{array}{l}\text { Se IX } \\
\text { Spent } \\
\text { SiRien }\end{array}$ & $\begin{array}{l}\text { Decon } \\
\text { Sall Soln }\end{array}$ & $\begin{array}{c}\text { IX } \\
\text { Food b } \\
\text { DWPF }\end{array}$ \\
\hline mbor & & $2 \mathrm{~T}_{2}$ & $20 b$ & 21 & 220 & $22 b$ & 23 & 30 & 318 & $\frac{10}{316}$ & 10 & 50 \\
\hline
\end{tabular}

\begin{tabular}{|c|c|c|c|c|c|c|c|c|c|c|c|c|}
\hline $\begin{array}{l}\text { Walor } \\
\text { KoH } \\
\text { Nongcos }\end{array}$ & $\begin{array}{r}8626 \\
1.8 \\
193\end{array}$ & 61 & 61 & 32 & 32 & 32 & \begin{tabular}{r|}
8659 \\
8.8 \\
193
\end{tabular} & 77 & 374 & 374 & $\begin{array}{r}8735 \\
88 \\
193\end{array}$ & 153 \\
\hline $\begin{array}{l}\text { Nessou } \\
\text { NaAl(OH)A } \\
\text { NeNCe }\end{array}$ & $\begin{array}{l}220 \\
398 \\
485\end{array}$ & & & & & & $\begin{array}{l}220 \\
398 \\
465\end{array}$ & & & & $\begin{array}{l}220 \\
398 \\
465\end{array}$ & \\
\hline $\int_{a}$ & $\begin{array}{r}848 \\
612\end{array}$ & $\mathrm{con}$ & & 2.5 & & & $\mid \begin{array}{r}71620 \\
614\end{array}$ & 6.0 & & & $\begin{array}{r}1960 \\
620\end{array}$ & 0.243 \\
\hline su & $\begin{array}{r}1.66 E .85 \\
1.11 E .04 \\
0.01\end{array}$ & & & & & 0.691 & T:86E:05 & & & a.86E:-05 & & $\begin{array}{r}1.66 E \\
1.11 E-045\end{array}$ \\
\hline Sulo & & & & & 3.6 & & & & & & & $\begin{array}{r}2.3 \\
16.4\end{array}$ \\
\hline $\begin{array}{l}\text { Sratea } \\
\text { NaTizOSH } \\
\text { Frit }\end{array}$ & & & & & & & & & 7.0 & & & \\
\hline $\begin{array}{l}\text { iocon } \\
\text { incos } \\
\text { almas }\end{array}$ & & & & & & & & & & & & \\
\hline
\end{tabular}

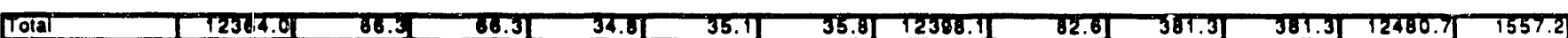

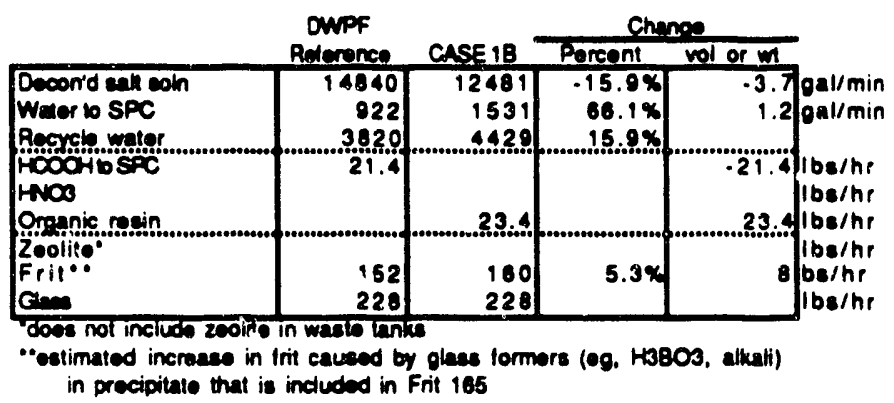




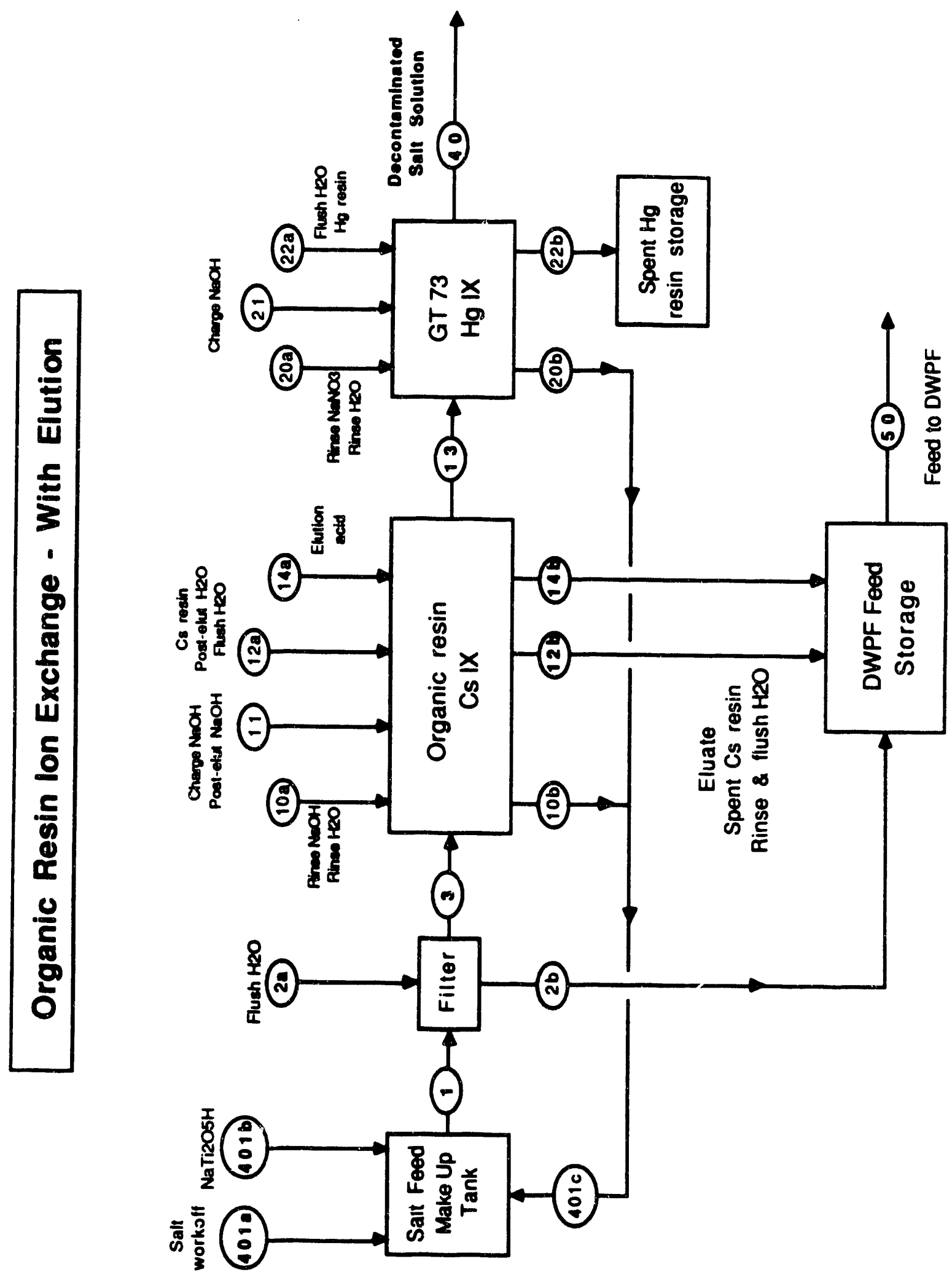


IX Technology Assessment Report

WSRC-RP-92-1093

CASE $2 A$

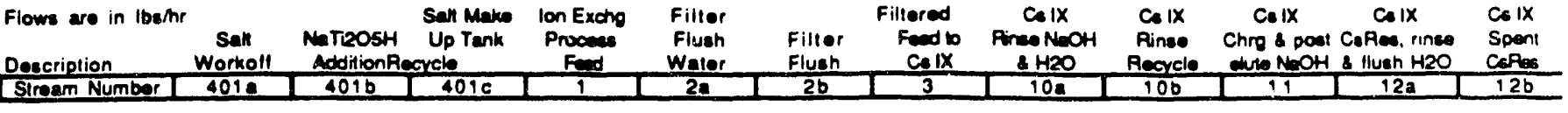

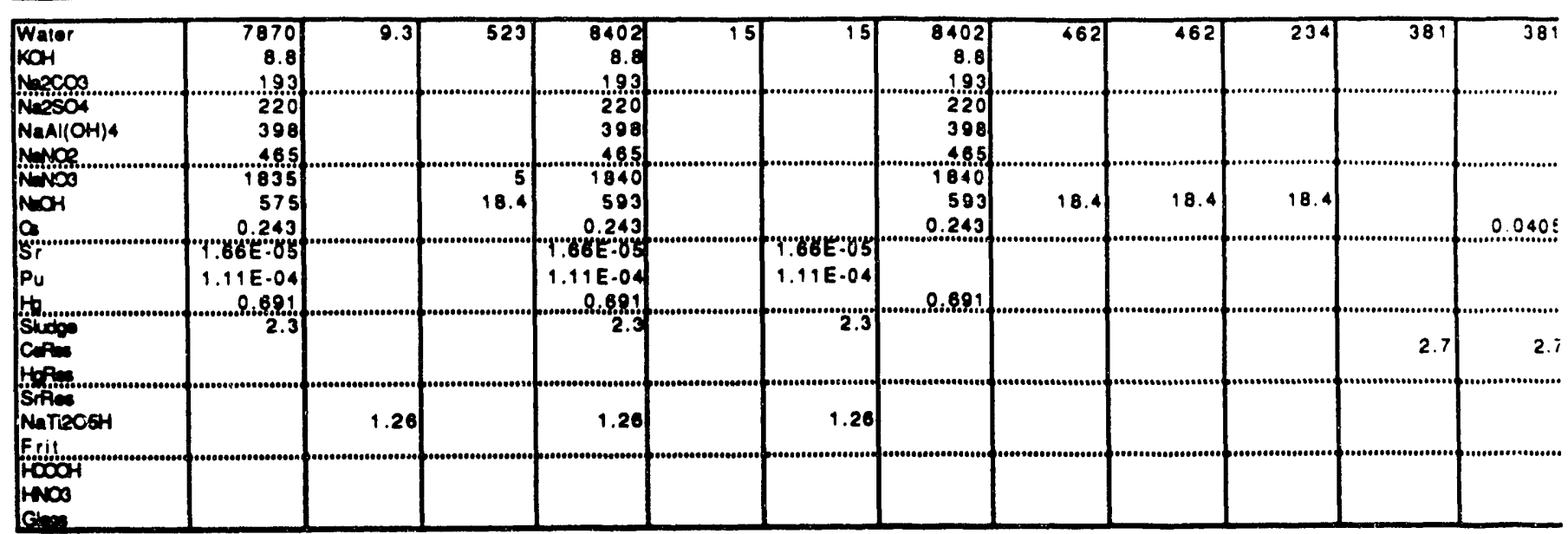

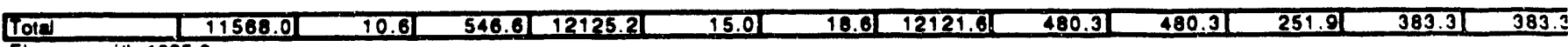

Flow - vathrios5.3
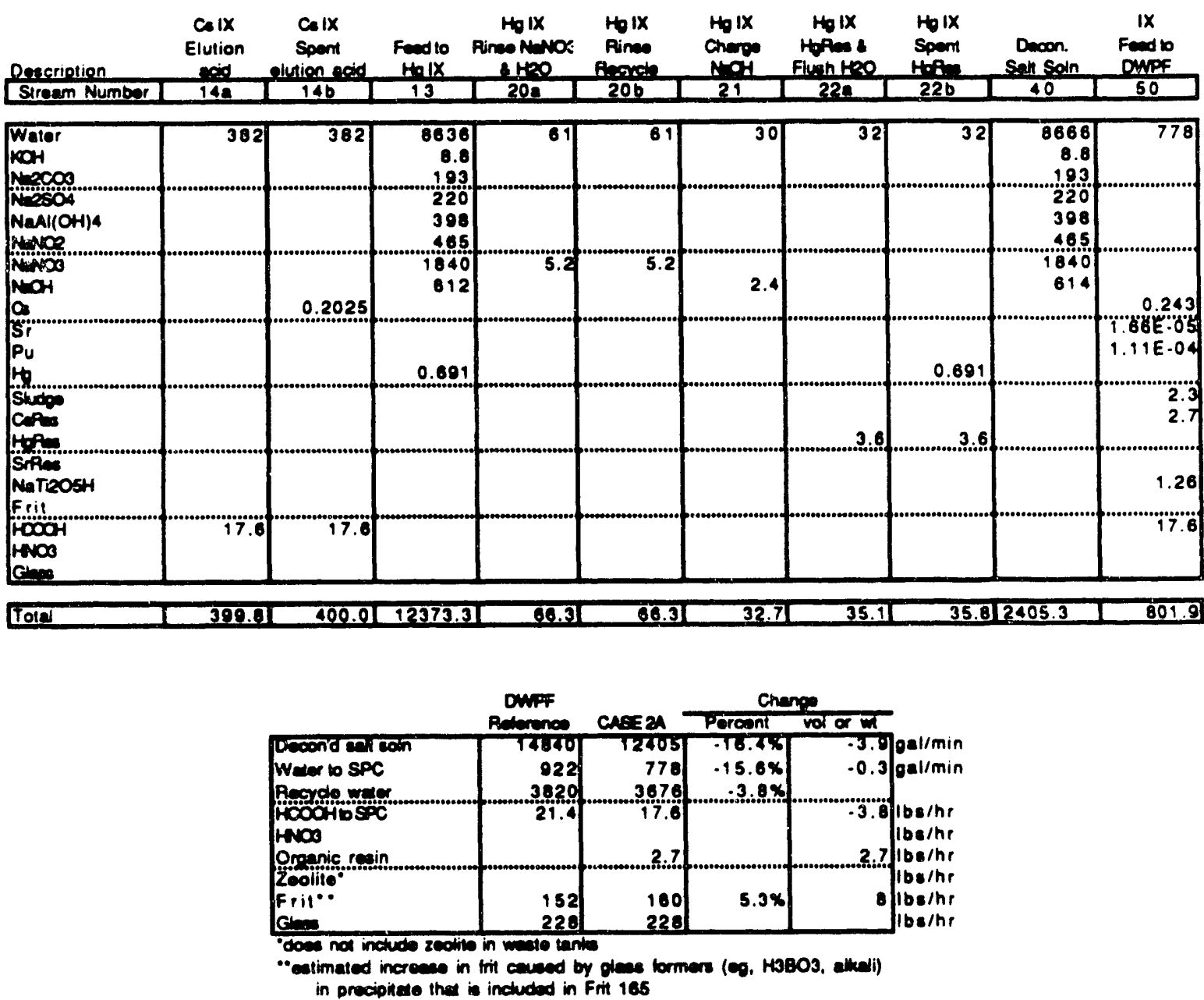
IX Technology Assessment Report

WSRC-RP-92-1093
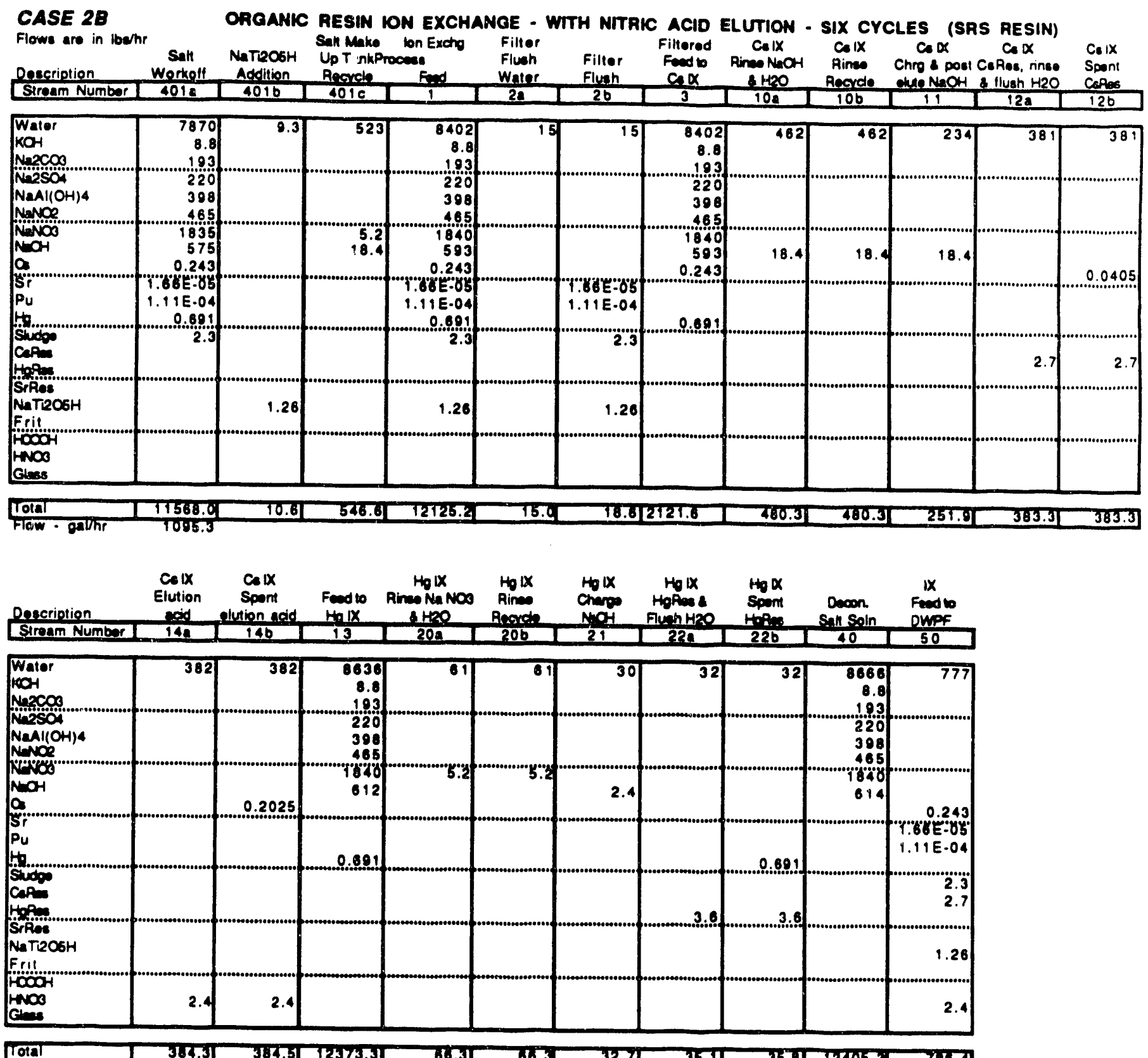

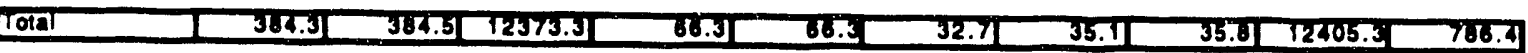

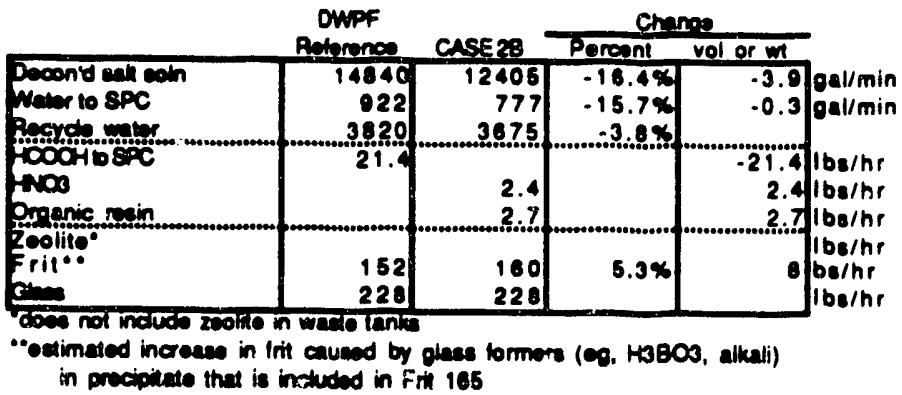




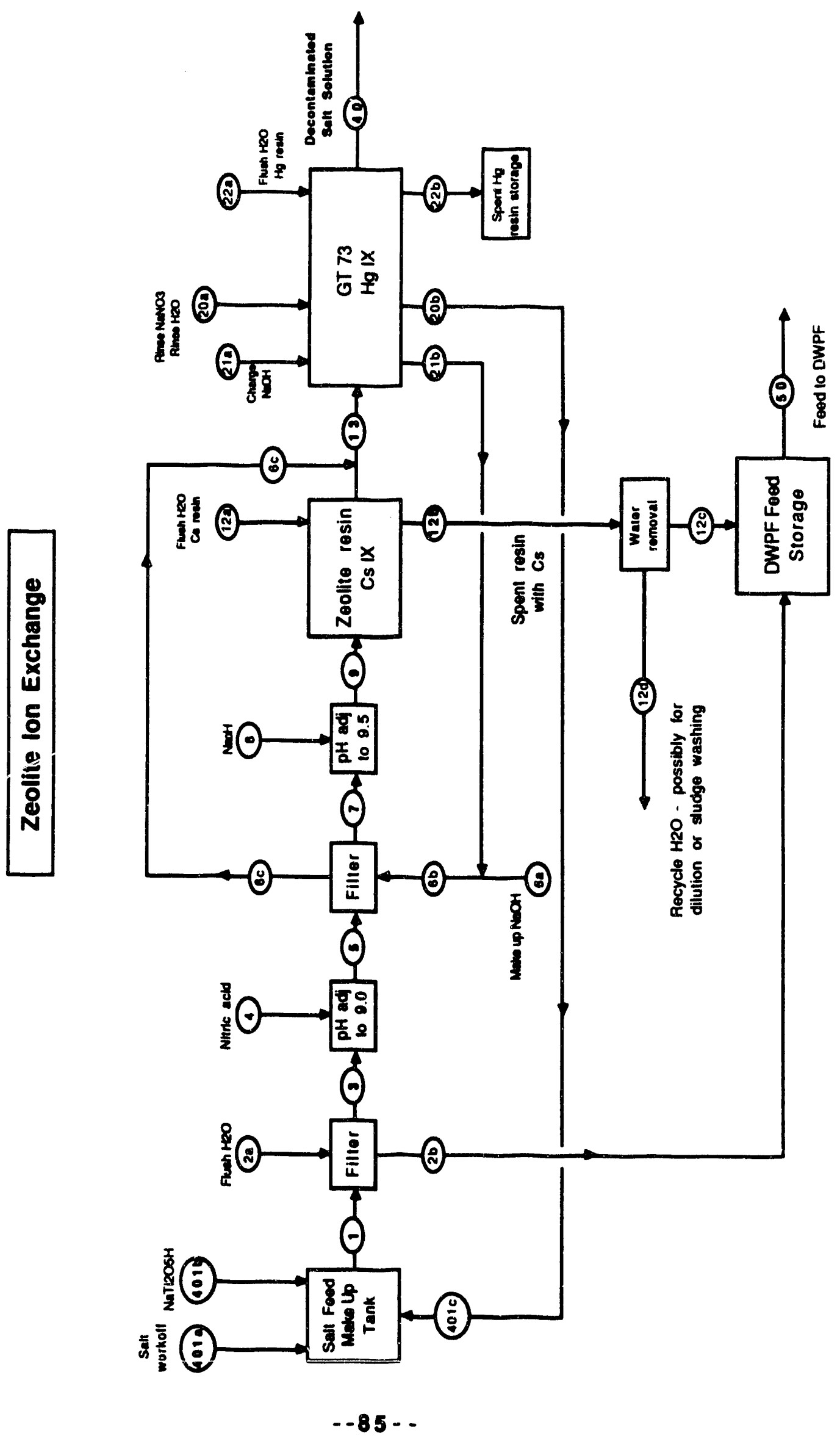



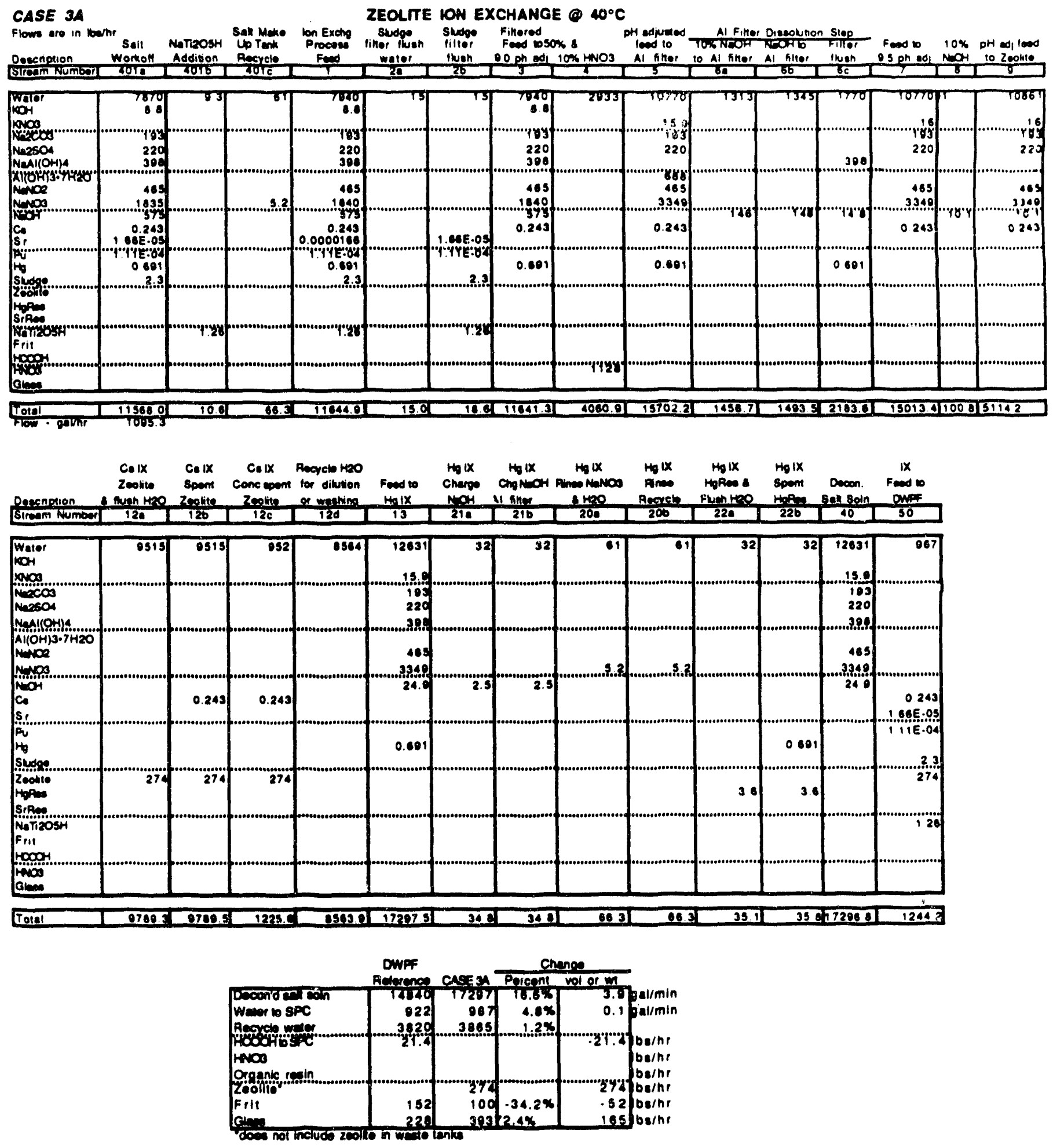
CASE 38 ZEOLTE ION EXCHANGE $10^{\circ} \mathrm{C}$

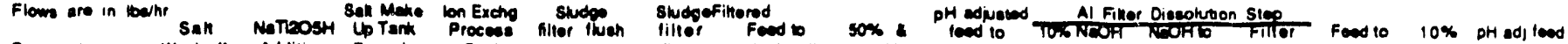

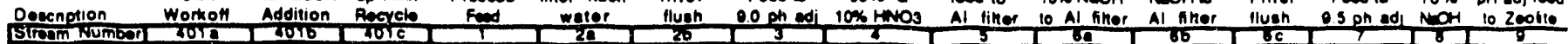

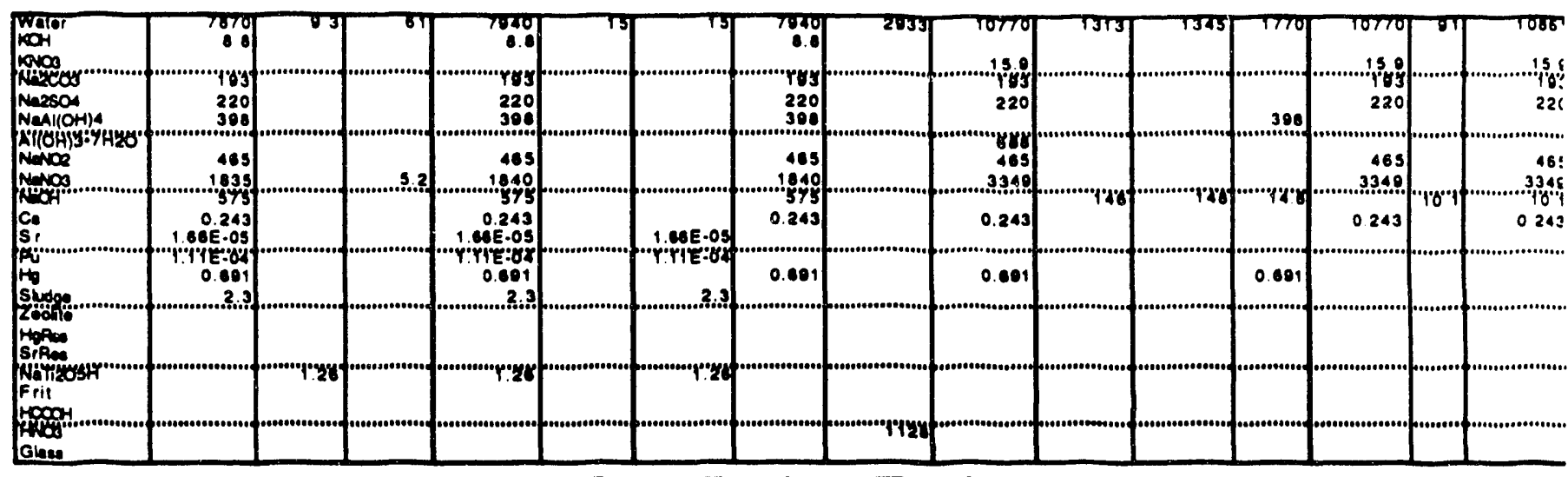

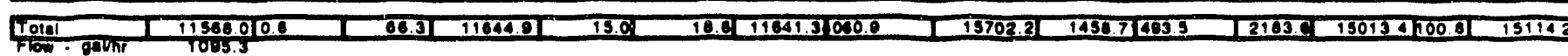

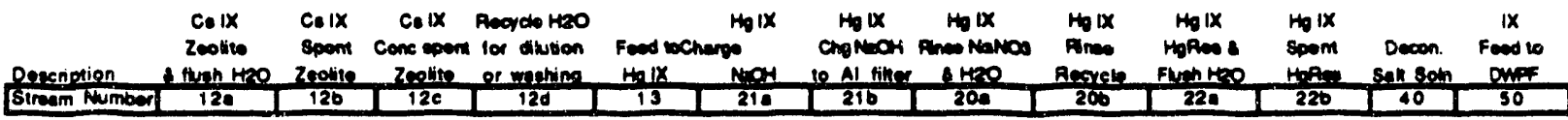
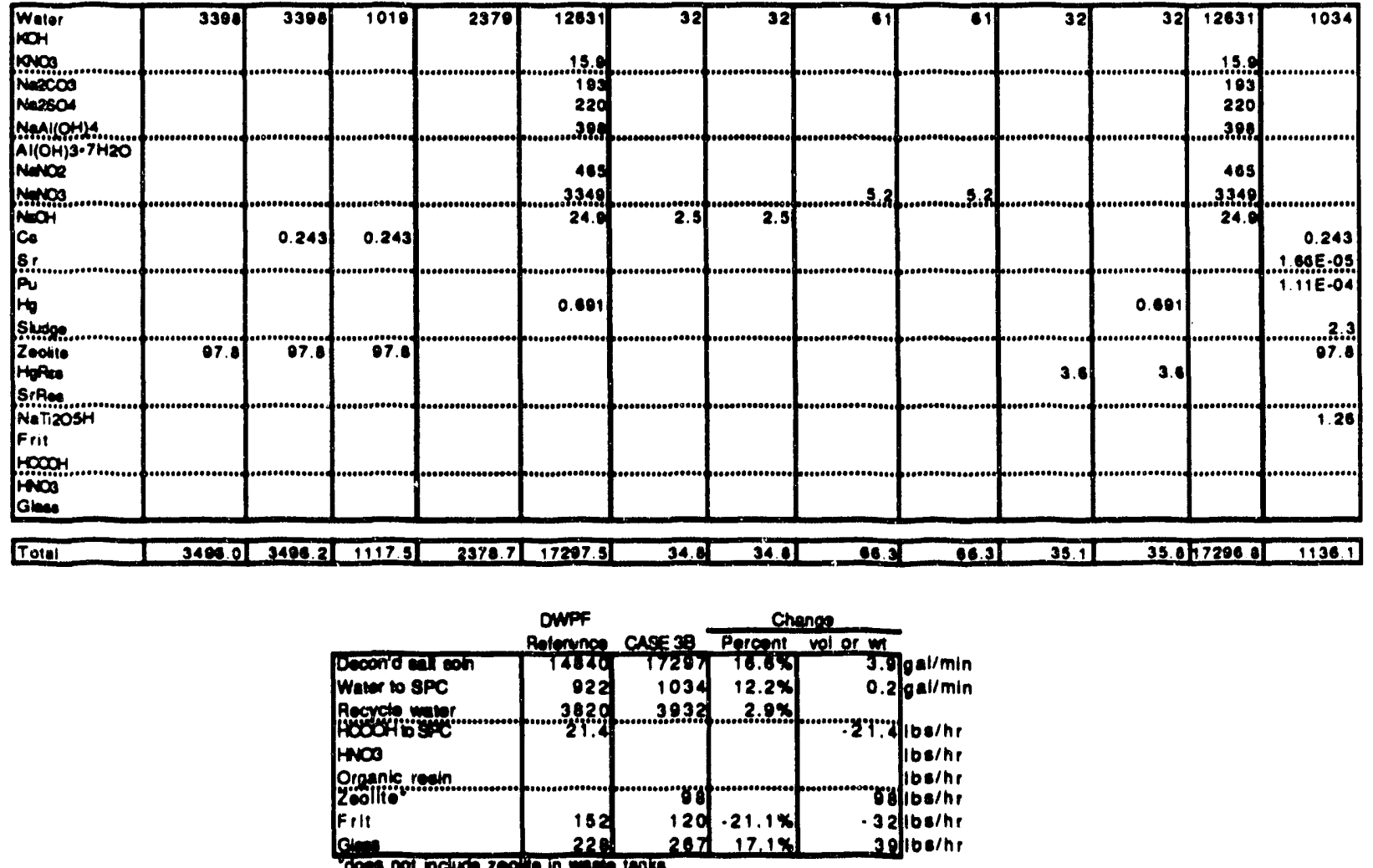


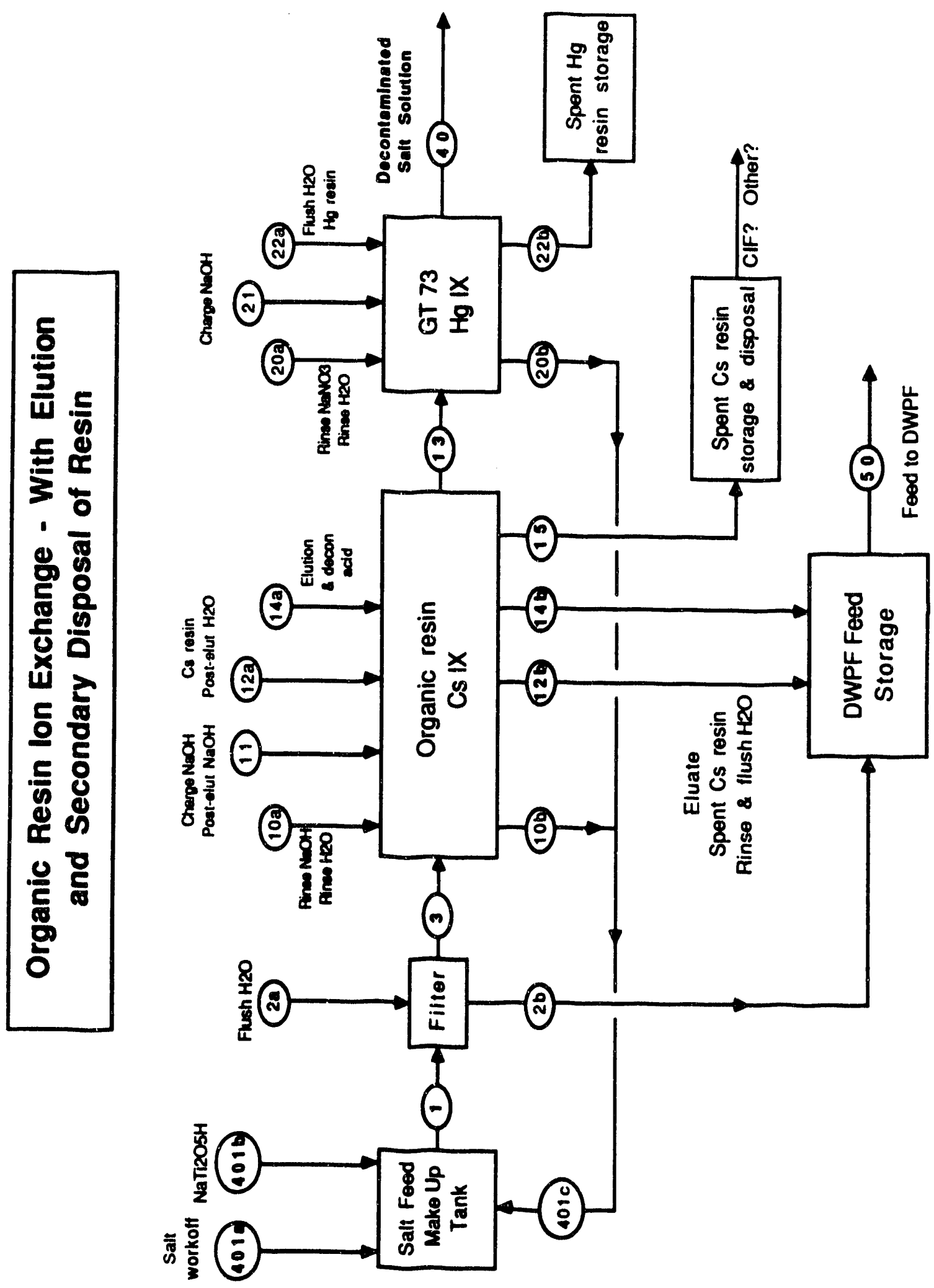


IX Technology Assessment Report

WSRC-RP-92-1093

CASE 4 OROANIC AESIN ION EXCHANGE - WITH FORMIC ACID ELUTION (6X) - WITH RESIN DISPOSAL

\begin{tabular}{|c|c|c|c|c|c|c|c|c|c|c|c|c|}
\hline$m$ & $\begin{array}{c}\text { Salt } \\
\text { Workolf }\end{array}$ & $\begin{array}{l}\text { NaTi } \\
\text { Ade }\end{array}$ & $\begin{array}{l}\text { San Make } \\
\text { Up. Tank } \\
\text { Regreh }\end{array}$ & $\begin{array}{l}\text { Ion Excho } \\
\text { Proceses } \\
\text { Fend }\end{array}$ & $\begin{array}{l}\text { Filter } \\
\text { Flush } \\
\text { Water }\end{array}$ & $\begin{array}{l}\text { Filter } \\
\text { Flugh } \\
\end{array}$ & $\begin{array}{l}\text { Filtered } \\
\text { Fend to } \\
\text { CeIX }\end{array}$ & $\begin{array}{c}\cos x \\
\text { Rineo } \mathrm{NaOH}^{-1} \\
\text { \& } \mathrm{H}_{2} \mathrm{O}\end{array}$ & $\begin{array}{c}\text { Cax } x \\
\text { Rines } \\
\text { Regreis }\end{array}$ & $\begin{array}{c}\text { Co } 1 x \\
\text { Chro \& posel } \\
\text { elue } \mathrm{NaOH}^{2}\end{array}$ & $\begin{array}{c}\text { Ces } x \\
\text { CoRos. nnes } \\
\text { s lluen } \mathrm{H} 2 \mathrm{O}\end{array}$ & $\begin{array}{c}\text { Coix } \\
\text { Postielute } \\
\text { HeO }\end{array}$ \\
\hline & & & & & & $2 b$ & & & & & & \\
\hline
\end{tabular}
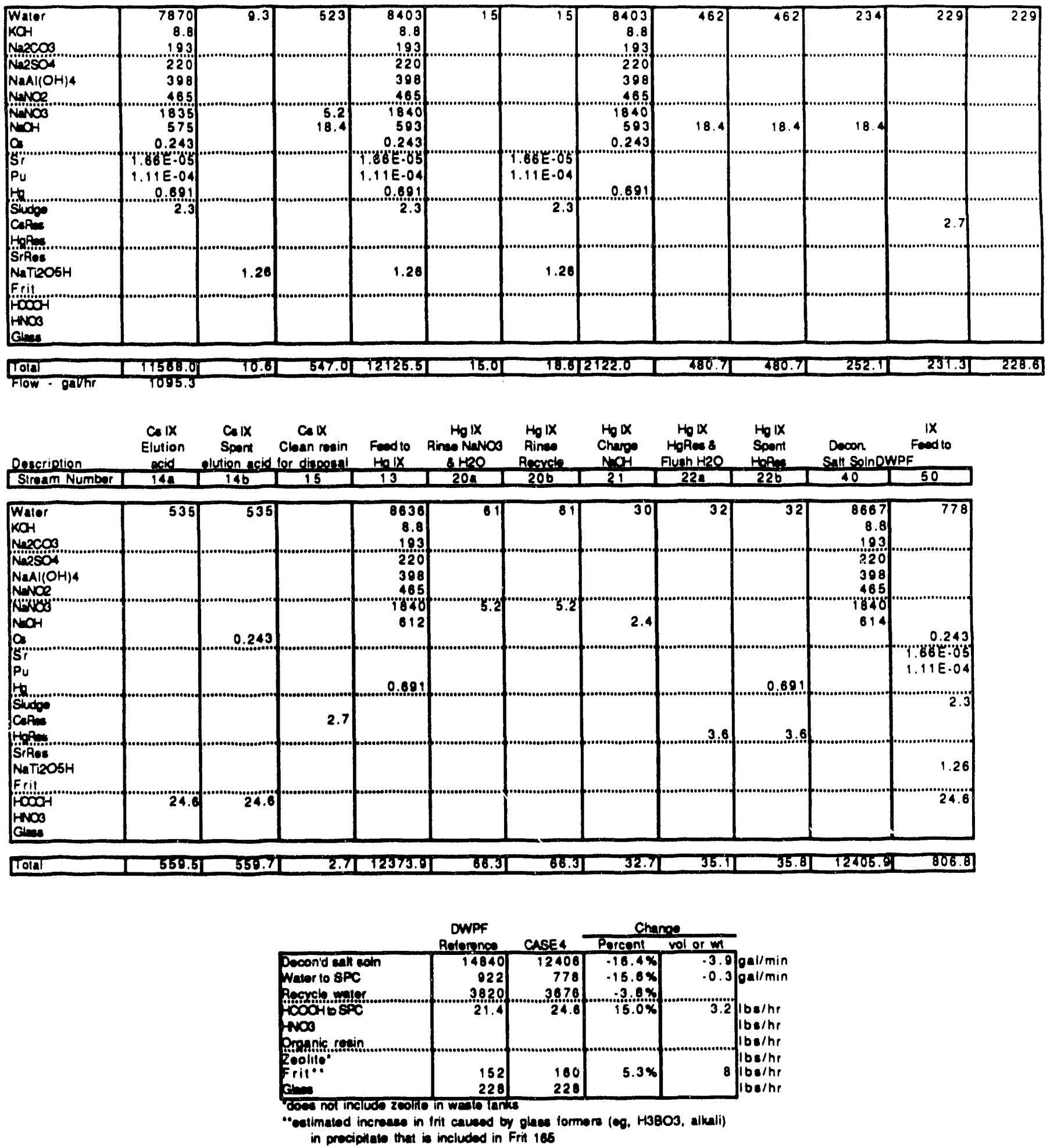


\section{APPENDIX C}

\section{IMPACTS OF ION EXCHANGE PROCESS ON WASTE ACCEPTANCE PROGRAMS}

\section{INTRODUCTION AND SUMMARY}

Ion exchange processes for the removal of cesium from Savannah River Site high-level waste are being considered as potential replacements for the current precipitation process. If adopted, an ion exchange process would significantly affect the programs by which the DWPF will establish compliance with repository specifications. In this report, the effects on the DWPF Waste Acceptance programs are detailed.

- Substituting an ion exchange process would have a very positive impact on Waste Acceptance programs carried out during production. Significant cost savings would be realized, and control of the vitrification process would be simplified.

- The impacts on Waste Acceptance programs for qualification purposes would be more complex. Some additional activities would be required, but their costs would be offset by the likelihood that the review process would proceed more smoothly.

\section{WASTE ACCEPTANCE}

The Department of Energy has established specifications for the DWPF product to ensure that it is acceptable for disposal in a repository. 1 These specifications cover the glass, the canister, the final product, and quality assurance. The DWPF establishes compliance with these specifications in four ways.

- The Waste Form Compliance Plan (WCP) details the DWPF's strategy for compliance with each specification. Of particular importance in this context is that the WCP describes the actions to be taken when a major change in the vitrification process (such as ion exchange) occurs. The WCP also describes those portions of the Startup Test Program which will be used to qualify the DWPF process. The impacts of process changes on those portions of the Startup Test Program related to Waste Acceptance have recently been identified.

- The Waste Form Qualification Report (WQR) documents the results of carrying out the programs described in the WCP which establish the ability of the DWPF to comply with the specifications. The most important volume of the WQR is the description of the Glass Product Control Program (GPCP). The GPCP describes the program by which the DWPF will ensure that the glass product meets the specification dealing with glass durability ("product consistency specification"). This is likely to be the most expensive of the Waste Acceptance programs carried out during production.

- The Production Records will provide detailed information about the nature of the DWPF product (e.9., chemical composition, radionuclide inventory), as well as establishing compliance with the specifications.

- The Storage and Shipping Records will provide information necessary for shipment and disposal of the DWPF product. They will also identify any unexpected events which occurred during storage of the canister in the Glass Waste Storage Building. 


\section{WASTE ACCEPTANCE PROGRAMS AFFECTED BY ADOPTION OF ION EXCHANGE}

The adoption of an ion exchange process will not affect compliance with most of the specifications. Compliance with the specifications related to the canister, or to exclusion of foreign materials, is not affected at all by changes upstream of the melter. On the other hand, compliance with specifications which relate to either the chemical composition of the product, or the radiogenic properties of the product, potentially could be affected by adoption of ion exchange. Based on the WCP, adoption of ion exchange would affect the following programs.

\section{Qualification Proorams}

Chemical composition projections. Adoption of an ion exchange process would entail approximately 2 person-months of effort for this program. A flowsheet would have to be developed for the actual process adopted. This would be used to identify an appropriate frit composition, and to project a final glass composition. It is very probable that the frit specified for a previous sludge-only flowsheet (Frit 165) would be suitable for this application, because the ion exchange processes will contribute relatively little to the glass. This would require that the DWPF order Frit 165, and discard any other frit on hand. An estimated cost for this is $\$ 1$ million.

Samples of the projected glass would be prepared and subjected to the thermal regimen of a full, scale canister. The phases formed would be identified, and the heat-treated samples would be subjected to the Product Consistency Test (PCT).

Phase stability. Adoption of an ion exchange process would entail approximately 3 personmonths of effort for this program. Samples of the projected glass composition would be heated to temperatures between $500-1000^{\circ} \mathrm{C}$ for various times. These samples would then be analyzed by $x$-ray diffraction, and subjected to the PCT. This is a conservative estimate, because use of Frit 165 would allow us to use data previously generated for sludge-only flowsheets, thus cutting the level of effort.

Badienuclide inventory proiections. Adoption of an ion exchange process would entail approximately 1 person-month of effort for this program. The flowsheet would be used to modify the current curie balance, in order to calculate a radionuclide inventory at time of production. In turn, this would be used to calculate a radionuclide inventory in the years 2025 and 3125 , as required by the specifications.

Dese rate and heat aeneration proiections. Adoption of an ion exchange process would entail approximately 1 person-month of effort for this program. The radionuclide iriventory would be used to calculate both dose rate and heat generation projections using standard conversion faciors.

Qualification Runs. Adoption of the ion exchange program will not affect the Qualification Runs. As discussed in a recent report, 3 the Qualification Runs will qualify the DWPF's ability to reliably produce glass which meets the specifications. As discussed in reference 3 , the DWPF Waste Acceptance programs are structured so that the DWPF may make any process changes which are needed as long as it is demonstrated that

The correlation between PCT results and glass composition which is used to control the glass product remains valid 
- The heological properties of the melter feed and final glass do not stray outside the design envelope of the Slurry Mix Evaporator, Melter Feed Tank, and melter.

The correlation currently in use was developed using Frit 165 glasses. Thus, it is valid for both ion exchange and precipitate hydrolysis glasses. The rheology of melter feed slurries is primarily controlled by the sludge. Thus, adoption of an ion exchange process is unlikely to significantly affect the rheology of melter feed slurries.

External reviews. A major hidden cost of the Waste Acceptance qualification programs is the extensive review process. As will be discussed in the section on ensuring feed acceptability, adoption of an ion exchange process reduces the probability of making a glass which fails to meet specifications. This considerably simplifies the control of the process, which, in turn, will smooth the review process. Though difficult to quantify, the savings could amount to as much as six person-months.

\section{Production Proarams - Glass Product Control Proaram (GPCP)}

The only production Waste Acceptance program affected by adoption of an ion exchange process would be the Glass Product Control Program. The GPCP is the program the DWPF will use to reliably produce a glass which meets the specifications. The GPCP consists of three major elements: qualification of waste, ensuring feed acceptability, and reporting. Adoption of an ion exchange process offers significant cost savings for both qualification of the waste, and in ensuring foed acceptability.

Qualification of the waste. Adoption of an ion exchange process would result in savings related to qualification of waste of approximately $\$ 1$ million per year. Qualification of the waste starts with sampling the batches of waste in the Tank Farm. The chemical and radiochemical composition of these samples are then determined. The chemical analyses are used to ensure that the frit currently in use in the DWPF is suitable for the new waste batches. For the precipitate process, this must be done every three to four months (whenever the precipitate batch changes). Adoption of an ion exchange process would reduce the frequency to once every two to three years coinciding with changes in the sludge batch (because of the modest contribution of an ion exchange process to the final glass composition).

Ensuring feed acceptability. Adoption of an ion exchange process would ai,$j$ simplify process control. The goal of the current process is to mix three streams to produce a glass which satisfies product specifications, and which can be reliably processed in the DWPF equipment. For a given batch of sludge in the Slurry Receipt and Adjustment Tank, this means that errors in either the amount of PHA added, or in the amount of frit added, will produce an "unacceptable" glass product (seo Figure 1).

The ion exchange processes being considered would add very little material to the glass. Use of a frit such as Frit 165 corresponds to a fixed ratio of Frit 202 and PHA. Thus, adoption of an ion exchange process would allow the process control triangle in Figure 1 to be collapsed to a straight line. For a given batch of sludge in the Slurry Receipt and Adjustment Tank, this means that only an error in the amount of frit added will produce an "unacceptable" glass product (see Figure 2). Since there is only one type of error to be considered, adoption of an ion exchange process would simplity DWPF process control. This in turn would smooth the review process, because of the greater simplicity of the process control system, and the resulting higher confidence in its success.

Reduction in the number of ways that a batch could be improperly made also implies fewer 


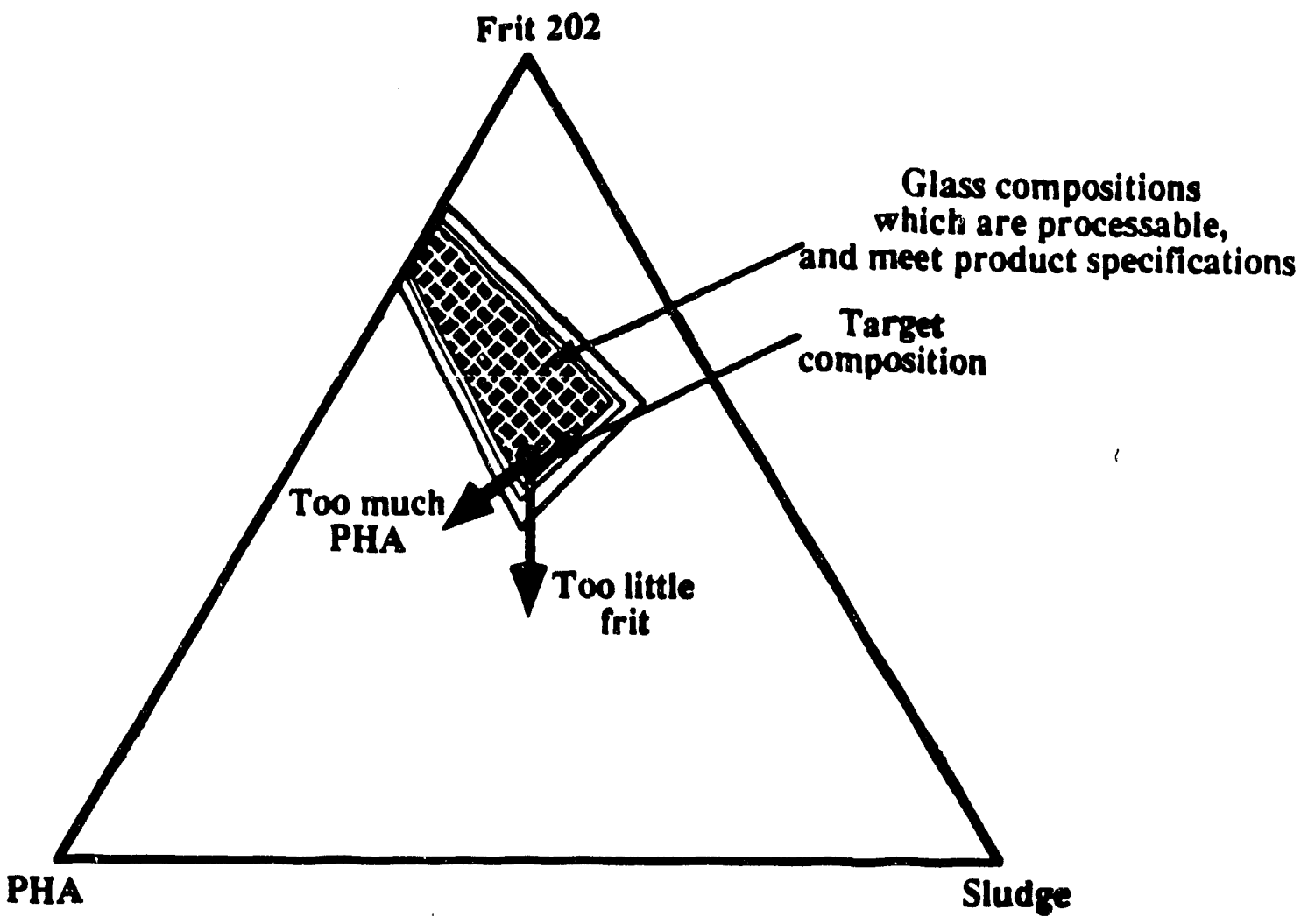

\section{Tigure 1. Possible exrors in melter laed proparation for pm procese.}

process upsets because of mis-batching, and a more reliable process. Based on experience gleaned from several glass manufacturers, batching errors go up approximately as the square of the number of possible errors. If this holds true for the DWPF, then adoption of an ion exchange process could reduce the number of batches needing remediation to one-fourth of those for the current process, and thereby lead to improved attainment.

\section{CONCLUSION}

Based on this review of the impact of adoption of an ion exchange process on Waste Acceptance programs, it appears that the overall impact would be beneficial. Process control would be simplified, and the number of process upsets due to mis-batching would be reduced. However, some additional activities would be required during qualification. The cost of these additional activities would be at least partially offset by the likelihood that external reviews would proceed more smoothly. 
IX Technology Assessment Report

WSRC-RP-92-1093

\section{Frit 165}

(a fixed mixture of

Frit 202 and PHA)

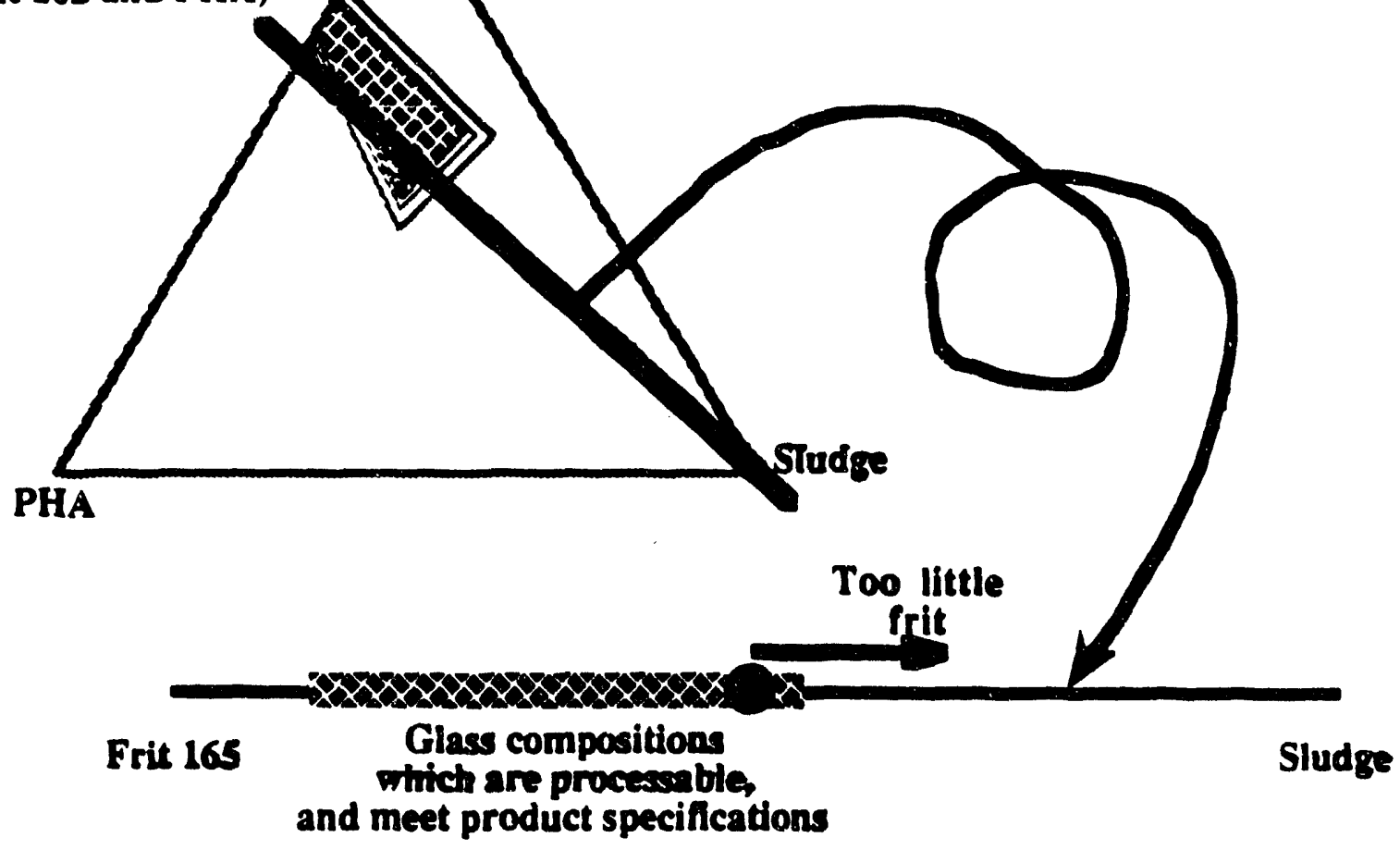

rigure 2. Posabble erross in melter feed preparation for ion exchange processes.

\section{BEEERENCES}

Waste Acceptance Preliminary Specifications for Vitrified High-Level Waste Forms, Waste Acceptance Prellminary Specificatlons for Vitrifled High-Level Waste Fcrms, DRAFT, June, 1991. 


\section{APPENDIX D}

\section{PROCESS UNCERTAINTIES AND OPPORTUNITIES}

Certain key process considerations are enlarged upon in this Appendix, because they may have a large impact on the IX decision, strategy, process, design or cost.

\section{GLASS LOADINGSALT WORKOFF POTENTIAL}

The ion exchange eluate stream (or loaded resin) contains minimal glassforming ingredients, compared with the ITP/PHA product containing large amounts of $\mathrm{B}, \mathrm{K}$, and $\mathrm{Na}$. The carbon: cesium ratio in IX product is fairly constant and independent of the Cs concentration in feed salt. Thus, the amount of IX product DWPF can accept will be limited primarily by Cs-137. In contrast, both the ITP processing rate and the PHA acceptance rate will at times be limited by the potassium content of the salt. If the IX process and its supporting salt removal and preparation facilities are built with excess throughput capacity, low-cesium/high potassium salt can be processed much faster. DWPF can accept the Cs product and Saltstone has ample excess processing capacity (vaults would have to be built faster).

This means that with IX, salt workoff can be accelerated and the production of fewer glass canisters is possible. In theory, if IX is implemented soon enough relative to sludge startup, salt and sludge workoff rates can be better matched. The excess salt, left after all sludge is vitrified, may be reduced or even eliminated.

\section{MERCURY REMOVAL}

Removal of mercury from salt waste may not be necessary. Mercury removal is included in the recommended reference IX process only because ITP removes it. In the original process described in the DWPF EIS(1), IX was used to remove Cs, Sr, and Pu from salt. Mercury was not removed from the decontaminated salt waste disposal product, then called "saltcrete". Data and models showed that $\mathrm{Hg}$ concentrations in groundwater below saltcrete vaults would be less than $10 \%$ of the saie drinking water standard (EIS page 5-34).

When the ITP process was adopted, it was found that mercury precipitates as biphenyl mercury along with the Cs and KTPB, and follows these precipitates into the DWPF Salt Cell, where it becomes an additional process, corrosion, and operational consideration. The removal of mercury from Saltstone feed has become part of the permit culture, although it is not an explicit requirement. The current Saltstone feed specification for $\mathrm{Hg}$ is $500 \mathrm{mg} / \mathrm{L}(2)$, based on EP. toxicity testing. (3) TCLP tests(4) suggest that the mercury feed specification should be reduced to $350 \mathrm{mg} / \mathrm{L}$. The average mercury content of reconstituted salt solution is only $76 \mathrm{mg} / \mathrm{L}$ (from Appendix B).

The deletion of Hg-removal columns from the IX process would save the cost of the equipment (including a cold feed $\mathrm{NaNO}_{3}$ tank) and associated building space. Small reductions in water and chemicals (GT-73, NaNO3) would be achieved. With or without mercury removal, IX will not send the $\mathrm{Hg}$ to DWPF. 
IX Technology Assessment Roport

WSRC-RP-92-11093

\section{SODIUM TITANATE}

The amount of sodium titanate (ST, $\mathrm{NaTi}_{2} \mathrm{O}_{5} \mathrm{H}$ ) needed for $\mathrm{Sr} / \mathrm{Pu}$ removal in the IX flowsheet vs the ITP flowsheet is uncertain because ITP "triple batches" this material in order to reduce the total amount needed. The DWPF feed acceptance limit on titanium corresponds to a glass product limit of $1.0 \% \mathrm{TiO}_{2}$. ST is the only significant source. The overall DWPF/Tank Farm material balance shows about half of this amount of ST being used in ITP. This same rate was adopted for the IX balance (Appendix B). However, ITP design was not based on that material balance. Also, the IX feed makeup process does not lend itself to triple batching ST, although that might be feasible. The Saltstone acceptance limits on Sr and Pu may allow less DF than presently expected in ITP.

Thus, more study is needed to determine the DF's achievable by single-batching the amount of ST acceptable to DWPF. If this process is unacceptable to either DWPF or Saltstone, multi-batching may be considered (decanting the solution from the ST may be problematic). As a fallback, $\mathrm{Sr}$ and Pu can be removed in an additional IX column Irain.

There is a safety aspect to this issue if ST can adsorb enough $U$ and Pu that the matrix could be made critical. SRTC is currently resolving this for ITP.

\section{DECOUPLNG}

Decoupling salt processing from sludge vitrification has been proposed previously and is being practiced in some fashion at both Hanford and West Valley. The high Kd of resorcinol-formaldehyde resin would theoretically enable reducing the soluble (cesium) waste at SRS from 100 million gallons of salt solution to less than $1 / 2$ million gallons of loaded resin (heat removal ignored). Even if the cesium were transferred to an inorganic medium such as zeolite for long-term storage, the volume would be inanageable. Decoupling would be attractive if pure cesium waste could be disposed of locally, instead of in a Federal Repository. Glass is only one form that could be considered.

Realistically, at this point few options are still open at SRS. Complete decoupling would probably have to involve some ITP operation, and the precipitate is a much less desirable and less compact interim form than $I X$ resin. Partial decoupling, either in conjunction with $I X$ startup or if a significant amount of salt remains when all sludge has been vitrified, might still be attractive if a low-cost cesium waste form and disposal option is developed.

\section{PREFILTRATION}

The requirements for prefiltration of SRS IX feed are undetermined, and prefiliration may not be needed at all. This question has been complicated by the recommendation to retain in-tank adsorption of Sr and Pu on ST, which must then be filtered. This recommendation was based in large part on the premise that sludge filtration would be needed anyway. If sludge filtration were not needed, it would protiably be less costly to remove Sr and PU by IX downstream of Cs IX, where the activity level would be low.

The zeolite IX columns at West Valley were successfully operated without prefiltration, although a prefilter (sintered metal crossflow) is provided and has been used most of the time. In that system IX feed is decanted from a tank containing sludge. Some IX experts believe that IX columns can tolerate considerable undissolved solids, and/or they can act as their own prefilters without a serious attainment pienalty. However, certain hydrated metal oxides are known to plug or blind IX media. Existing and planned IX facilities at Sellafield (SIXEP), WV, and Hanford have prefilters as a 
matter of principle. It is interesting to note that the original IX process described in the DWPF EIS included polyelectrolyte (flocculant), heating (digestion), gravity clarification, and two stages of sand filtration. The technical bases for this elaborate prefiltration system have not yet been recovered.

\section{DISPOSAL OF DECONTAMINATED AQUEOUSHORGANIC LOUID (TRANSITION PROCESS)}

In the transition to IX from ITP, dissolution of the $K(C s) T P B$ in a number of water-miscible organic solvents has been demonstrated, and no major technical problems are foreseen in processing the resultant solution by IX to remove the cesium. However, no assured treatment or disposal option has been identified for the resultant decontaminated liquid. This liquid will probably be $>50 \%$ organics including ionic radiolysis products, soluble TPB's, the solvent, and if $\mathrm{Hg}$ removal $\mathrm{IX}$ is deleted from the process, dissolved diphenyl mercury. Up to 2 million gallons may be created.

Direct disposal (e.g., in Saltstone) is probably not feasible unless the material can be stored and blended off slowly. Incineration is an obvious treatment option. The possibility of burning this high-water, possibly high-mercury liquid in the CIF will be investigated. Other treatment processes such as pyro-reforming and mediated electrochemical oxidation will be considered, but such facilities do not exist at SRS.

\section{References}

1. DOE-EIS-0082, Final Environmental Impact Statement, DWPF, February, 1982.

2. WSRC-RP-89-1375, "Revised Z-Area Salt Solution Feed Specifications for Mercury, "C. A. Langton and E. L. Wilhite, 1/23/90.

3. DPST-89-314, "Guidance on Z-Area Salt Solution Toxic Metal Concentrations Based on EP Toxicity Tests for Saltstone," 2/22/89.

4. Waste Management '88, "Metal Toxicity Evaluation of Savannah River Plant Saltstone Comparison of EP and TCLP Test Results," C. A. Langton. 
IX Technology Assessment Report

WSRC-RP.92-1093

\section{APPENDIX E \\ IX PROCESSING OF WASH AND RECYCLE STREAMS}

This report has addressed the Task Team charter to evaluate the technology of ion exchange as a potential replacement for the ITP/LW/PH processes to decontaminate SRS salt HLW and prepare the radioactive concentrate for vitrification. Meanwhile, a proposal to apply $I X$ to certain intermediate waste streams (instead of committing them to the Tank Farm system) has been advanced. ${ }^{1}$ Because the IX technology would be similar, if not identical, and because this application would complement ITP/LW/PH as well as provide contingency technology and other benefits, it is included here for consideration.

In the proposal, IX facilities would be installed to directly decontaminate DWPF recycle and sludge washes, instead of sending these to the Tank Farm for evaporation, salt storage, and eventual redissolution and processing through ITP/LW/PH. The radioactive product (loaded resin or eluate) would be low in volume and could be stored until eventual feeding to DWPF. The decontaminated salt solution from this $\mathrm{IX}$ process would be fed directly to Saltstone or, to reduce its volume, it could be concentrated in a low-level (unshielded) evaporator for disposal in Saltstone (bottoms) and ETF (condensate). Because the DWPF recycle and sludge wash streams stand to be the bulk of future water and salt additions to the Tank Farm, direct processing by IX would complement ITP in reducing the Tank Farm inventory. At the same time a backup and/or replacement technology for ITP/LW/PH would be established.

This proposal has not been evaluated. The IX Technology Task Team recommends that such an evaluation be made, either as an extension of their effort or as a separate, relatively small, endeavor. The IX technology described in this report should be completely applicable, but material balances, flow diagrams and descriptions, and an implementation strategy need to be developed.

\section{References:}

1. Boersma, M. D., "Direct Decontamination of ESP Washwater and DWPF Recycle Water by by Ion Exchang:: SRT-DWP-92-0020, September 4, 1992. 

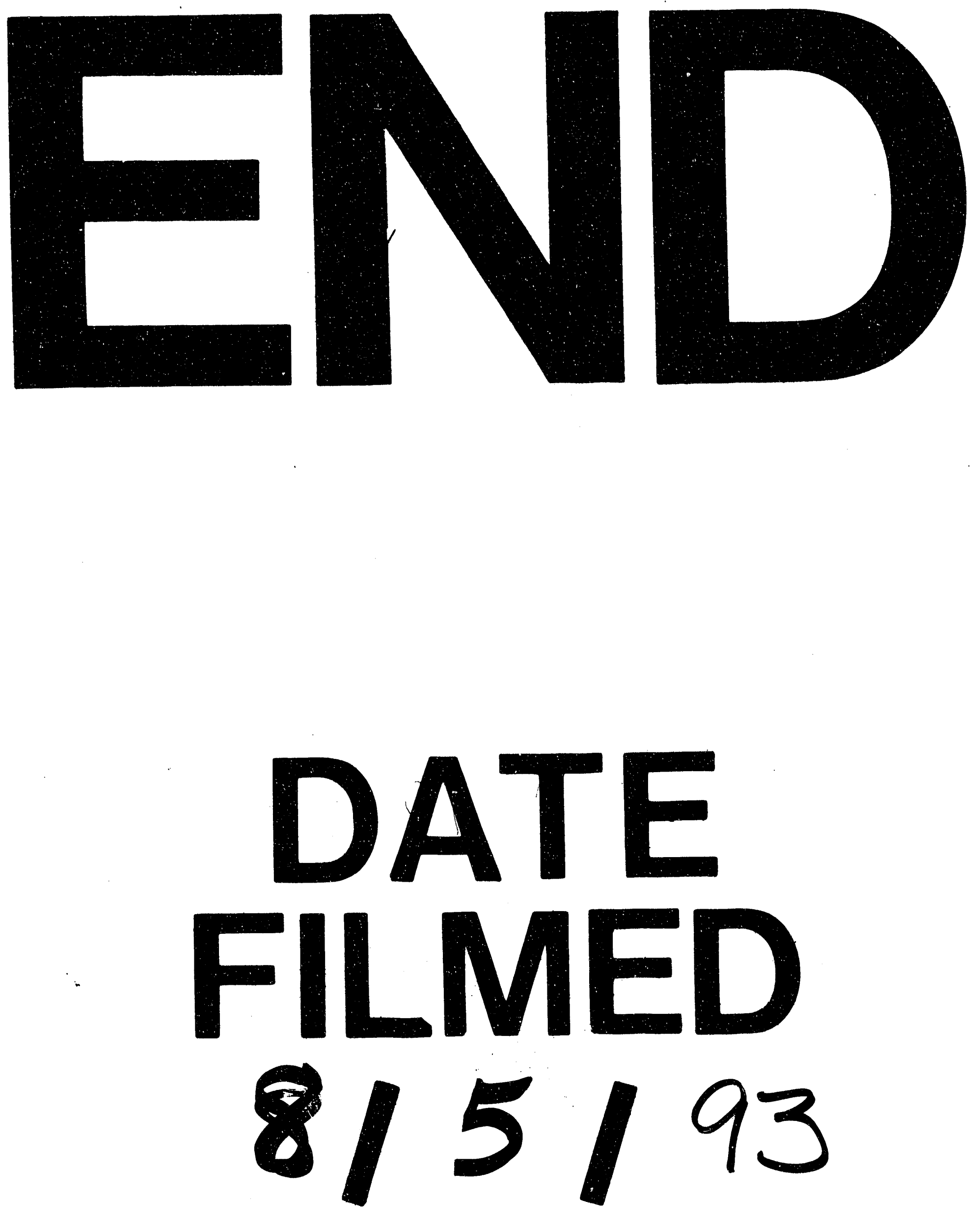
A 